Prepared in cooperation with the Chester County Water Resources Authority

\title{
Evaluation of Long-Term Trends in Hydrologic and Water- Quality Conditions, and Estimation of Water Budgets through 2013, Chester County, Pennsylvania
}

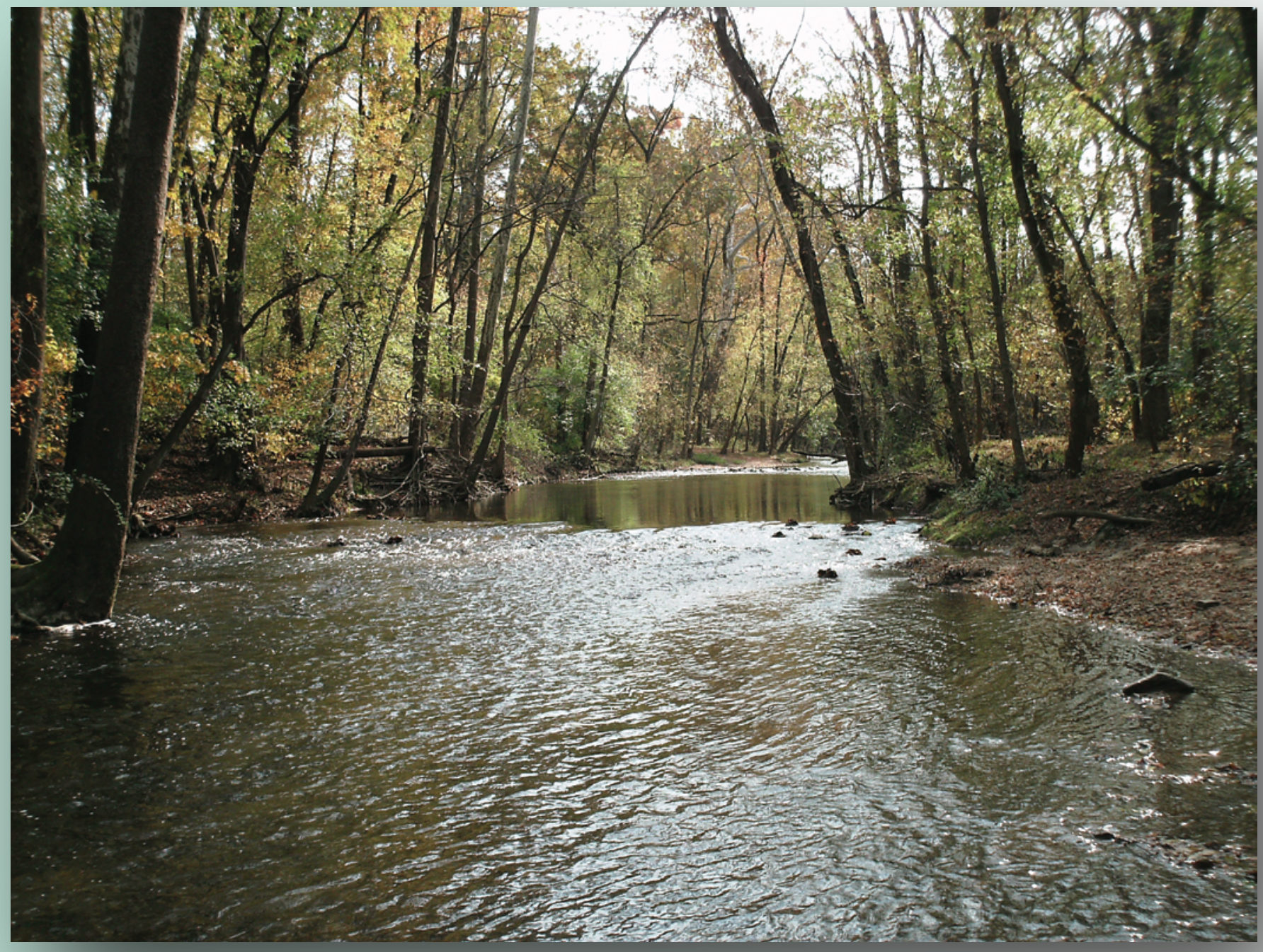

Scientific Investigations Report 2017-5025

Version 1.1, July 2017

U.S. Department of the Interior

U.S. Geological Survey 
Cover: Photo of Valley Creek near Valley Forge, Pa. (Photograph provided by Andrew Reif, U.S. Geological Survey) 


\section{Evaluation of Long-Term Trends in Hydrologic and Water-Quality Conditions, and Estimation of Water Budgets Through 2013, Chester County, Pennsylvania}

By Ronald A. Sloto and Andrew G. Reif

Prepared in cooperation with the

Chester County Water Resources Authority

Scientific Investigations Report 2017-5025

Version 1.1, July 2017 


\title{
U.S. Department of the Interior \\ RYAN K. ZINKE, Secretary
}

\section{U.S. Geological Survey William H. Werkheiser, Acting Director}

\author{
U.S. Geological Survey, Reston, Virginia: 2017 \\ Revised: July 2017 (ver. 1.1)
}

\begin{abstract}
For more information on the USGS - the Federal source for science about the Earth, its natural and living resources, natural hazards, and the environment—visit http://www.usgs.gov or call 1-888-ASK-USGS.

For an overview of USGS information products, including maps, imagery, and publications, visit http://store.usgs.gov.
\end{abstract}

\author{
Any use of trade, firm, or product names is for descriptive purposes only and does not imply endorsement by the \\ U.S. Government. \\ Although this information product, for the most part, is in the public domain, it also may contain copyrighted materials \\ as noted in the text. Permission to reproduce copyrighted items must be secured from the copyright owner. \\ Suggested citation: \\ Sloto, R.A., and Reif, A.G., 2017, Evaluation of long-term trends in hydrologic and water-quality conditions, and \\ estimation of water budgets through 2013, Chester County, Pennsylvania (ver. 1.1, July 2017): U.S. Geological Survey \\ Scientific Investigations Report 2017-5025, 59p., https://doi.org/10.3133/sir20175025. \\ ISSN 2328-0328 (online)
}




\section{Contents}

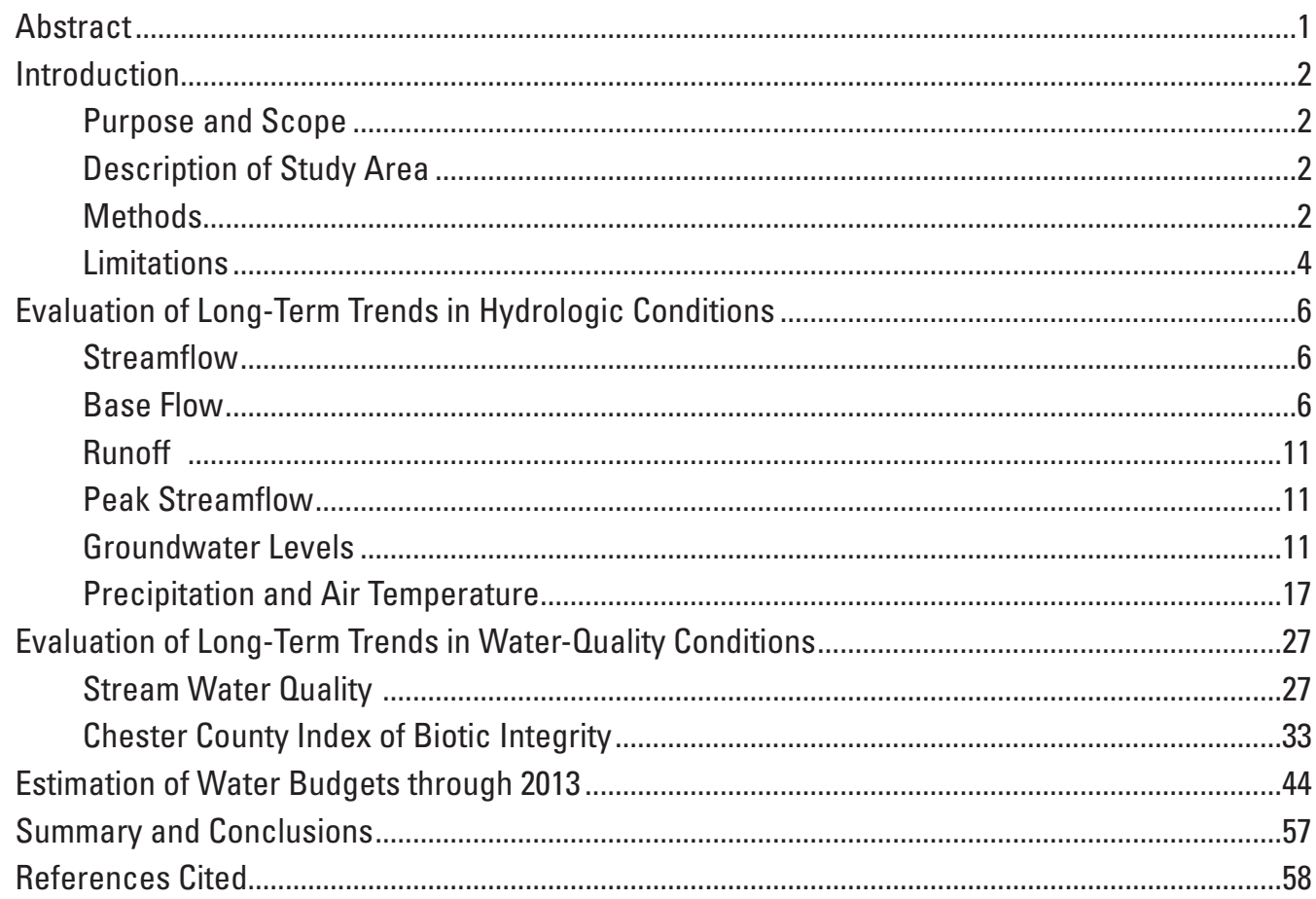

\section{Figures}

1. Map showing location of streamgages and drainage areas/basins in Chester County, Pennsylvania .................................................................................................

2. Graph showing population of Chester County, Pennsylvania, 1900-2013..........................4

3. Map showing location of monitoring wells in the Chester County Observation Well Network and National Oceanic and Atmospheric Administration weather stations, Chester County, Pennsylvania, and vicinity

4. Graph showing annual mean precipitation in southeastern Pennsylvania from the National Oceanic and Atmospheric Administration, Southeastern Pennsylvania Piedmont Climate Division, 1960-2013

5. Graph showing December mean streamflow at streamgage 01481000, Brandywine Creek at Chadds Ford, Pennsylvania, 1962-2013 ........................................

6. Graph showing annual mean streamflow at streamgage 01480300, West Branch Brandywine Creek at Honey Brook, Pennsylvania, 1961-2013 ........................................10

7. Graph showing December mean base flow at streamgage 01481000 , Brandywine Creek at Chadds Ford, Pennsylvania, 1963-2013 ...........................................................10

8. Graph showing October mean runoff at streamgage 01480700, East Branch Brandywine Creek near Downingtown, Pennsylvania, 1965-2013.

9. Gragph showing peak streamflow above a base streamflow of 3,500 cubic feet per second at streamgage 01481000, Brandywine Creek at Chadds Ford, Pennsylvania, 1962-2012 
10. Graph showing number of annual peak streamflows equal to or greater than the 2-year recurrence interval at streamgage 01473169, Valley Creek at Pennsylvania Turnpike Bridge near Valley Forge, Pennsylvania, 1989-2013

11. Graph showing peak streamflow equal to or greater than the 2-year recurrence interval at streamgage 01473169 , Valley Creek at Pennsylvania Turnpike Bridge near Valley Forge, Pennsylvania, 1989-2013 15

12. Graph showing annual mean water level in well $\mathrm{CH}-10$, Chester County, Pennsylvania, 1952-2013. .15

13. Graph showing annual range in water-level fluctuation in well $\mathrm{CH}-10$, Chester County, Pennsylvania, 1952-2013. .18

14. Graph showing November mean water level in well CH-6513, Chester County, Pennsylvania, 2002-13. 18

15. Graph showing relation between annual mean water level in well CH-3289, Chester County, Pennsylvania, and annual mean streamflow at streamgage 01472157, French Creek near Phoenixville, Pennsylvania, 1969-2013.

16. Graph showing relation between annual mean water level in well CH-5422, Chester County, Pennsylvania, and annual mean base flow at streamgage 01480617, West Branch Brandywine Creek at Modena, Pennsylvania, 2000-13.

17. Graph showing number of days per year with precipitation equal to or greater than 0.1 inch at West Chester, Pennsylvania weather station, 1893-2013.

18. Graph showing annual mean minimum temperature in Chester County, Pennsylvania, from the National Oceanic and Atmospheric Administration, Southeastern Pennsylvania Piedmont Climate Division, 1896-2014

19. Graph showing annual mean maximum air temperature in Chester County, Pennsylvania, from the National Oceanic and Atmospheric Administration, Southeastern Pennsylvania Piedmont Climate Division, 1896-2014

20. Graph showing number of days per year with a maximum air temperature equal to or greater than 90 degrees Fahrenheit at West Chester Pennsylvania weather station, 1893-2013.

21. Graph showing estimated average annual snowfall in Chester County, Pennsylvania. 1894-2013.

22. Graph showing annual mean specific conductance at stream water-quality stations 01481000, Brandywine Creek at Chadds Ford, Pennsylvania; 01480617, West Branch Brandywine Creek at Modena, Pennsylvania; and 01480870, East Branch Brandywine Creek below Downingtown, Pennsylvania, 1974-2013. .32

23. Graph showing estimated increase in annual mean specific conductance at stream water-quality stations 01481000 , Brandywine Creek at Chadds Ford, Pennsylvania; 01480617, West Branch Brandywine Creek at Modena, Pennsylvania; and 01480870, East Branch Brandywine Creek below Downingtown, Pennsylvania, 2014-50.

24. Graph showing chloride concentration in relation to streamflow at water-quality monitoring station 01481000, Brandywine Creek at Chadds Ford, Pennsylvania, 1948-2013

25. Graph showing annual mean $\mathrm{pH}$ at stream water-quality stations 01481000 , Brandywine Creek at Chadds Ford, Pennsylvania; 01480617, West Branch Brandywine Creek at Modena, Pennsylvania; and 01480870, East Branch Brandywine Creek below Downingtown, Pennsylvania, 1974-2013.

26. Graph showing annual mean dissolved oxygen concentration at water-quality station 01480617, West Branch Brandywine Creek at Modena, Pennsylvania, 1974-2013 
27. Graph showing mean monthly specific conductance at water-quality station 01480617, West Branch Brandywine Creek at Modena, Pennsylvania, 1974-2013.........36

28. Graph showing mean monthly $\mathrm{pH}$ and dissolved oxygen concentration at water-quality station 01480617, West Branch Brandywine Creek at Modena, Pennsylvania, 1974-2013

29. Graph showing estimated increase in mean September specific conductance at water-quality station 01480617, West Branch Brandywine Creek at Modena, Pennsylvania, 1974-2013, 2014-50...

30. Graph showing Chester County Index of Biotic Integrity at station 01480870, East Branch Brandywine Creek below Downingtown, Pennsylvania, 1998-2013...........39

31. Map showing watersheds with available water budgets, Chester County, Pennsylvania

\section{Tables}

1. Kendall p-values for annual mean streamflow, base flow, and runoff at 10 streamgages in Chester County, Pennsylvania, and Cecil County, Maryland

2. Kendall p-values and slope for monthly mean streamflow, base flow, and runoff at 10 streamgages in Chester County, Pennsylvania and Cecil County, Maryland ...........8

3. Normalized mean annual base flow and 1-in-25-year base flow at 10 streamgages in Chester County, Pennsylvania, and Cecil County, Maryland

4. Kendall p-values for trends in peak streamflow above base streamflow at 12 streamgages in Chester County, Pennsylvania and Cecil County, Maryland.

5. Kendall p-values for trends in peak streamflow and number of peak streamflows equal to or greater than the 2-year recurrence interval at 11 streamgages in Chester County, Pennsylvania, and Cecil County, Maryland

6. Monitoring wells in the Chester County Observation Well Network in Pennsylvania used for statistical analysis

7. Kendall $p$-values for trends in annual mean groundwater levels in monitoring wells in the Chester County Observation Well Network, Pennsylvania

8. Kendall $p$-values for trends in monthly mean groundwater levels for monitoring wells in the Chester County Observation Well Network, Chester County, Pennsylvania

9. Correlation of annual mean groundwater levels for monitoring wells in the Chester County Observation Well Network with annual mean streamflow and base flow at a nearby U.S. Geological Survey streamgage.

10. Correlation between annual mean groundwater level and annual precipitation in Chester County Pennsylvania.

11. Kendall $p$-values for trends in annual mean precipitation and annual mean air temperature at Phoenixvile and West Chester, Pennsylvania weather stations

12. Kendall $p$-values for trends in monthly mean precipitation and monthly mean air temperature at Phoenixville and West Chester, Pennsylvania weather stations

13. Stream water-quality monitors in Chester County, Pennsylvania

14. Number of days per year stream water quality exceeded standards at water-quality monitoring station 01480617, West Branch Brandywine Creek at Modena, Pennsylvania, 1974-2014 
15. Number of days per year stream water quality exceeded standards at water-quality monitoring station 01480870, East Branch Brandywine Creek below Downingtown, Pennsylvania, 1974-2014

16. Number of days per year stream water quality exceeded standards at water-quality monitoring station 01481000, Brandywine Creek at Chadds Ford, Pennsylvania, 1974-2014

17. Kendall $\mathrm{p}$-values for trends in annual mean specific conductance, $\mathrm{pH}$, stream temperature, and dissolved oxygen concentration at selected water-quality monitoring stations in Chester County, Pennsylvania, 1974-2013.

18. Correlation between monthly mean specific conductance and monthly mean streamflow and base flow at selected water-quality monitoring stations in Chester County, Pennsylvania, 1974-2013

19. Kendall p-values for trends in Chester County Index of Biotic Integrity at selected streamgages in Chester County, Pennsylvania, 1998-2013.

20. Correlation of the Chester County Index of Biotic Integrity with streamflow and peak streamflow above a base at selected streamgages in Chester County, Pennsylvania, 1998-2013

21. Correlation of the Chester County Index of Biotic Integrity with precipitation and air temperature at selected National Oceanic and Atmospheric Administration stations in Chester County, Pennsylvania, 1998-2013.

22. Correlation of the Chester County Index of Biotic Integrity with specific conductance, $\mathrm{pH}$, stream temperature, and dissolved oxygen concentration in stream water at selected water-quality stations in Chester County, Pennsylvania, 1998-2013.

23. Summary of Kendall $p$-values for statistically significant trends in streamflow, groundwater levels, precipitation, temperature, water-quality characteristics and Chester County Index of Biotic Integrity at selected streamgages, wells, and weather stations in Chester County, Pennsylvania.

24. Water budget for French Creek watershed upstream from streamgage 01472157, French Creek near Phoenixville, Pennsylvania, 1969-2013...

25. Water budget for Red Clay Creek watershed upstream from streamgage 01479820, Red Clay Creek near Kennett Square, Pennsylvania, 1988-2013

26. Water budget for West Branch Brandywine Creek watershed upstream from streamgage 01480300, West Branch Brandywine Creek near Honey Brook, Pennsylvania, 1974-2013

27. Water budget for West Branch Brandywine Creek watershed upstream from streamgage 01480617, West Branch Brandywine Creek at Modena, Pennsylvania, 1978-2013

28. Water budget for Broad Run watershed upstream from streamgage 01480638, Broad Run at Northbrook, Pennsylvania, 2005-13.

29. Water budget for Marsh Creek watershed upstream from streamgage 01480675, Marsh Creek near Glenmoore, Pennsylvania, 1974-2013.

30. Water budget for East Branch Brandywine Creek watershed above streamgage 01480870, East Branch Brandywine Creek below Downingtown, Pennsylvania, 1977-2013

31. Water budget for Brandywine Creek watershed upstream from streamgage 01481000, Brandywine Creek at Chadds Ford, Pennsylvania, 1963-2013...

32. Water budget for Big Elk Creek watershed upstream from streamgage 01495000, Big Elk Creek at Elk Mills, Maryland, 1988-2013

33. Average water budget in Chester County, Pennsylvania, based on 2 to 9 individual watershed water budgets, 1969-2013. 


\section{Conversion Factors}

Inch/Pound to SI

\begin{tabular}{lcl}
\hline \multicolumn{1}{c}{ Multiply } & By & \multicolumn{1}{c}{ To obtain } \\
\hline inch (in.) & Length & millimeter $(\mathrm{mm})$ \\
foot (ft) & 25.4 & meter $(\mathrm{m})$ \\
mile (mi) & 0.3048 & kilometer $(\mathrm{km})$ \\
\hline & 1.609 & \\
\hline square mile $\left(\mathrm{mi}^{2}\right)$ & Area & square kilometer $\left(\mathrm{km}^{2}\right)$ \\
\hline & 2.590 & \\
\hline cubic foot per second $\left(\mathrm{ft}^{3} / \mathrm{s}\right)$ & Flow rate & cubic meter per second $\left(\mathrm{m}^{3} / \mathrm{s}\right)$ \\
\hline
\end{tabular}

Temperature in degrees Celsius $\left({ }^{\circ} \mathrm{C}\right)$ may be converted to degrees Fahrenheit $\left({ }^{\circ} \mathrm{F}\right)$ as follows: ${ }^{\circ} \mathrm{F}=\left(1.8 x^{\circ} \mathrm{C}\right)+32$.

Temperature in degrees Fahrenheit $\left({ }^{\circ} \mathrm{F}\right)$ may be converted to degrees Celsius $\left({ }^{\circ} \mathrm{C}\right)$ as follows: ${ }^{\circ} \mathrm{C}=\left({ }^{\circ} \mathrm{F}-32\right) / 1.8$.

Vertical coordinate information is referenced to the "North American Vertical Datum of 1988 (NAVD 88)."

Horizontal coordinate information is referenced to the "North American Datum of 1983 (NAD 83)."

Altitude, as used in this report, refers to distance above the vertical datum.

Specific conductance is given in microsiemens per centimeter at 25 degrees Celsius $\left(\mu \mathrm{S} / \mathrm{cm}\right.$ at $\left.25^{\circ} \mathrm{C}\right)$. 



\title{
Evaluation of Long-Term Trends in Hydrologic and Water- Quality Conditions, and Estimation of Water Budgets Through 2013, Chester County, Pennsylvania
}

\author{
By Ronald A. Sloto and Andrew G. Reif
}

\section{Abstract}

An evaluation of trends in hydrologic and water quality conditions and estimation of water budgets through 2013 was done by the U.S. Geological Survey in cooperation with the Chester County Water Resources Authority. Long-term hydrologic, meteorologic, and biologic data collected in Chester County, Pennsylvania, which included streamflow, groundwater levels, surface-water quality, biotic integrity, precipitation, and air temperature were analyzed to determine possible trends or changes in hydrologic conditions. Statistically significant trends were determined by applying the Kendall rank correlation test; the magnitudes of the trends were determined using the Sen slope estimator. Water budgets for eight selected watersheds were updated and a new water budget was developed for the Marsh Creek watershed. An average water budget for Chester County was developed using the eight selected watersheds and the new Marsh Creek water budget.

Annual and monthly mean streamflow, base flow, and runoff were analyzed for trends at 10 streamgages. The periods of record at the 10 streamgages ranged from 1961-2013 to 1988-2013. The only statistically significant trend for annual mean streamflow was for West Branch Brandywine Creek near Honey Brook, Pa. (01480300) where annual mean streamflow increased 1.6 cubic feet per second $\left(\mathrm{ft}^{3} / \mathrm{s}\right)$ per decade. The greatest increase in monthly mean streamflow was for Brandywine Creek at Chadds Ford, Pa. (01481000) for December; the increase was $47 \mathrm{ft}^{3} / \mathrm{s}$ per decade. No statistically significant trends in annual mean base flow or runoff were determined for the 10 streamgages. The greatest increase in monthly mean base flow was for Brandywine Creek at Chadds Ford, Pa. (01481000) for December; the increase was $26 \mathrm{ft}^{3} / \mathrm{s}$ per decade.

The magnitude of peaks greater than a base streamflow was analyzed for trends for 12 streamgages. The period of record at the 12 stream gages ranged from 1912-2012 to 2004-11. Fifty percent of the streamgages showed a small statistically significant increase in peaks greater than the base streamflow. The greatest increase was for Brandywine Creek at Chadds Ford, Pa. (01481000) during 1962-2012; the increase was $1.8 \mathrm{ft}^{3} / \mathrm{s}$ per decade. There were no statistically significant trends in the number of floods equal to or greater than the 2-year recurrence interval flood flow.
Twenty-one monitoring wells were evaluated for statistically significant trends in annual mean water level, minimum annual water level, maximum annual water level, and annual range in water-level fluctuations. For four wells, a small statistically significant increase in annual mean water level was determined that ranged from 0.16 to 0.7 feet per decade. There was poor or no correlation between annual mean groundwater levels and annual mean streamflow and base flow. No correlation was determined between annual mean groundwater level and annual precipitation. Despite rapid population growth and land-use change since 1950, there appears to have been little or no detrimental effects on groundwater levels in 21 monitoring wells.

Long-term precipitation and temperature data were available from the West Chester (1893-2013) and Phoenixville, Pa. (1915-2013) National Oceanic and Atmospheric Administration (NOAA) weather stations. No statistically significant trends in annual mean precipitation or annual mean temperature were determined for either station. Both weather stations had a significant decrease in the number of days per year with precipitation greater than or equal to $0.1 \mathrm{inch}$. Annual mean minimum and maximum temperatures from the NOAA Southeastern Piedmont Climate Division increased 0.2 degrees Fahrenheit (F) per decade between 1896 and 2014. The number of days with a maximum temperature equal to or greater than 90 degrees $F$ increased at West Chester and decreased at Phoenixville. No statistically significant trend was determined for annual snowfall amounts.

Data from 1974 to 2013 for three stream water-quality monitors in the Brandywine Creek watershed were evaluated. The monitors are on the West Branch Brandywine Creek at Modena, Pa. (01480617), East Branch Brandywine Creek below Downingtown, Pa. (01480870), and Brandywine Creek at Chadds Ford, Pa. (01481000). Statistically significant upward trends were determined for annual mean specific conductance at all three stations, indicating the total dissolved solids load has been increasing. If the current trend continues, the annual mean specific conductance could almost double from 1974 to 2050 . The increase in specific conductance likely is due to increases in chloride concentrations, which have been increasing steadily over time at all three stations. No correlation was found between monthly mean specific conductance and monthly mean streamflow or base flow. Statistically 
significant upward trends in $\mathrm{pH}$ were determined for all three stations. Statistically significant upward trends in stream temperature were determined for East Branch Brandywine Creek below Downingtown, Pa. (01480870) and Brandywine Creek at Chadds Ford, Pa. (01481000). The stream water-quality data indicate substantial increases in the minimum daily dissolved oxygen concentrations in the Brandywine Creek over time.

The Chester County Index of Biotic Integrity (CC-IBI) determined for 1998-2013 was evaluated for the five biological sampling sites collocated with streamgages. CC-IBI scores are based on a $0-100$ scale with higher scores indicating better stream quality. Statistically significant upward trends in the CC-IBI were determined for West Branch Brandywine Creek at Modena, Pa. (01480617) and East Branch Brandywine Creek below Downingtown, Pa. (01480870). No correlation was found between the CC-IBI and streamflow, precipitation, or stream specific conductance, $\mathrm{pH}$, temperature, or dissolved oxygen concentration.

A Chester County average water budget was developed using the nine estimated watershed water budgets. Average precipitation was 48.4 inches, and average streamflow was 21.4 inches. Average runoff and base flow were 8.3 and 13.1 inches, respectively, and average evapotranspiration and estimation of errors was 27.2 inches.

\section{Introduction}

Measurements of streamflow, groundwater levels, and surface-water quality have been collected throughout Chester County, Pennsylvania, by the U.S. Geological Survey (USGS) on a systematic basis for about 45 years. Analysis of these long-term datasets provides valuable insight into possible changes in the hydrologic system that may be caused by urbanization, climate, and (or) other factors.

This study determined statistically significant trends and relations in and among the following long-term hydrologic, meteorologic, and biologic data-streamflow, runoff, base flow, precipitation, air temperature, groundwater levels, surface-water quality, and biotic integrity. Water budgets were updated for eight selected watersheds, and a new water budget was developed for the Marsh Creek watershed. Water-budget components include precipitation, streamflow, runoff, base flow, change in groundwater storage, and evaporation and estimation errors. Where appropriate, estimates of changes in surface-water storage and imported or exported water were used. This study was done by the USGS in cooperation with the Chester County Water Resources Authority (CCWRA).

\section{Purpose and Scope}

The purpose of this report is to analyze long-term hydrologic data (greater than 10 years of record) collected in Chester County and to identify statistically significant temporal trends and relations. Data analyzed include streamflow, base flow, runoff, precipitation (rainfall and snowfall), air temperature, groundwater levels, stream water quality $(\mathrm{pH}$, temperature, dissolved oxygen concentration, and specific conductance collected at water-quality monitors), and biotic integrity for various periods from 1961 to 2013. The cause of any identified trends is beyond the scope of this study and is not discussed. Water budgets for eight selected watersheds were updated, and a new water budget was developed for the Marsh Creek watershed.

\section{Description of Study Area}

Chester County, which occupies 750.5 square miles $\left(\mathrm{mi}^{2}\right)$ in southeastern Pennsylvania (fig. 1), is a rapidly growing county; in 2013 the population was 509,468 (U.S. Census Bureau, 2014). The county has experienced a continuing rapid increase in population since 1950 (fig. 2). Most of this population growth is suburban with the conversion of farmland and woodland to housing developments.

The watersheds in Chester County encompass tributaries to the Delaware River and Chesapeake Bay. Delaware River tributaries include streams in the Christina River watershed (Brandywine, Red Clay, and White Clay Creeks), streams in the Schuylkill River watershed (French, Pickering and Valley Creeks), and streams that drain directly to the Delaware River (Darby, Crum, Ridley, and Chester Creeks) (fig. 1). Octoraro Creek drains to the Susquehanna River, and Big Elk Creek drains to the Elk River, before draining into the Chesapeake Bay.

\section{Methods}

Water-level, streamflow, and water-quality data for statistical analysis were compiled from the USGS National Water Information System (NWIS) database (U.S. Geological Survey, 2014). Climatic data, which includes precipitation (rainfall and snowfall) and temperature data, were compiled from National Oceanic and Atmospheric Administration (NOAA) monthly summaries (National Oceanic and Atmospheric Administration, 2014). The biological data used for statistical analysis were compiled from four USGS data reports. Complete analytical and biological results are given by Moore (1989) for 1969-80, Reif (1999) for 1981-94, Reif (2000) for 1995-97, and Reif (2004) for 1998-2000. Data collected from 2001 to 2013 were published in the USGS annual water-data reports for Pennsylvania (U.S. Geological Survey, 2002-13).

Statistically significant trends were determined by applying Kendall's rank correlation test (Kendall, 1938) and the Sen slope estimator (Sen, 1968). The Kendall rank correlation coefficient, typically referred to as Kendall's tau coefficient, is a statistic used to measure the association between two measured quantities. The test is a non-parametric hypothesis test for statistical dependence, based on the tau coefficient. Trends are considered statistically significant at the 95-percent or greater confidence level ( $\mathrm{p}=0.05$ or less). Upward trends are 


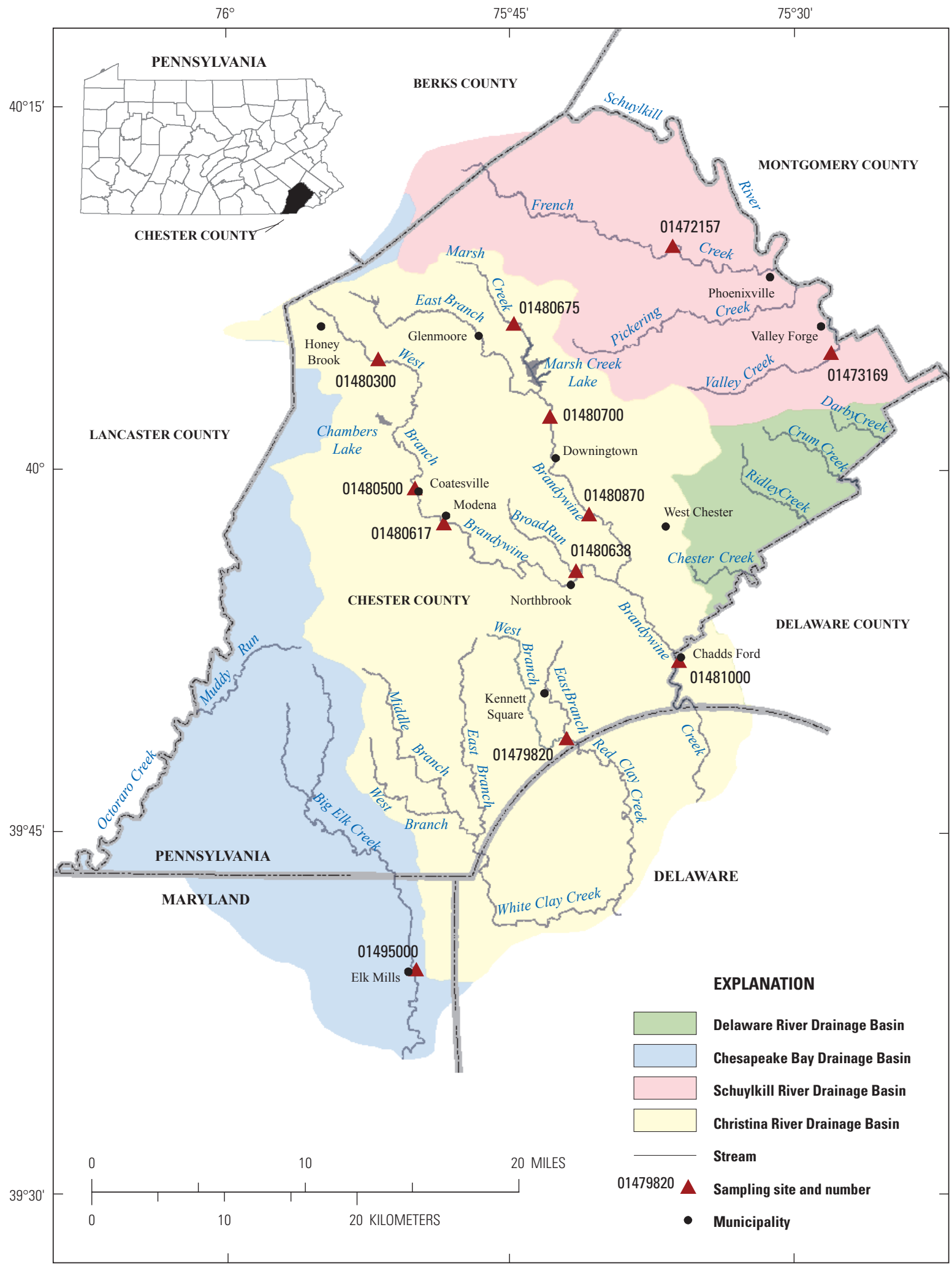

Base from U.S. Geological Survey digital data, 1983, 1:100,000 Universal Transverse Mercator Projection Zone 18

Figure 1. Location of streamgages and drainage areas/basins in Chester County, Pennsylvania. 


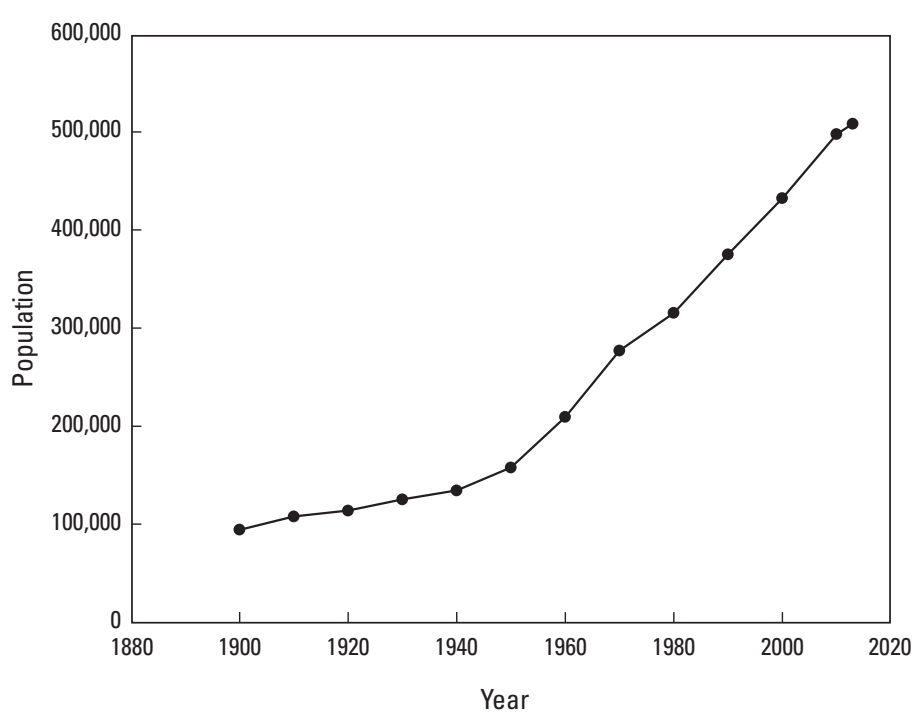

Figure 2. Population of Chester County, Pennsylvania, 1900-2013. (U.S. Census Bureau, 2014)

identified by a positive slope; downward trends are identified by a negative slope. For water level, the opposite is true.

Annual data consist of one value per year, generally the annual mean value. Monthly data consist of the monthly mean value for the period of record for each month of the year. Monthly values were tested for trends using the Kendall's tau test and the Sen slope. Trends were considered statistically significant at the 95-percent or greater confidence level ( $\mathrm{p}=0.05$ or less).

Correlations between variables were made using simple linear regression. For each regression, the correlation coefficient $\left(\mathrm{r}^{2}\right)$ was evaluated to determine whether a relation exists between the two variables.

A water budget integrates all the components of the hydrologic cycle for a single watershed. Under natural conditions, the hydrologic system is in long-term equilibrium. Averaged over a long period of time, the amount of water entering a watershed is approximately equal to the amount of water leaving the watershed plus changes in groundwater and surface-water storage. The water budget equation is

$$
\mathrm{P}+\mathrm{IMP}=\mathrm{SF} \pm \Delta \mathrm{GWS} \pm \Delta \mathrm{SWS} \pm \Delta \mathrm{SM}-\mathrm{EXP}+\mathrm{ET}
$$

where

$\begin{aligned} \mathrm{P} & \text { is precipitation, } \\ \mathrm{IMP} & \text { is water imported into the watershed, } \\ \mathrm{SF} & \text { is streamflow leaving the watershed, } \\ \Delta \mathrm{GWS} & \text { is change in groundwater storage, } \\ \Delta \mathrm{SWS} & \text { is change in surface-water storage } \\ & \text { (impoundments), } \\ \Delta \mathrm{SM} & \text { is change in soil moisture, } \\ \mathrm{EXP} & \text { is water exported from the watershed, and } \\ \mathrm{ET} & \text { is evapotranspiration plus errors in estimation } \\ & \text { of the other components. }\end{aligned}$

Water budgets were calculated on an annual basis with the start and end of the water budget in the early winter (January 1) when soil moisture is assumed to be at field capacity. Because the water budget begins and ends when the soil is assumed to be saturated, the change in soil moisture is zero. Only those terms applicable to a particular watershed are included in the equation for that watershed. All terms in the equation can be measured or reasonably estimated except ET. Thus the equation is solved for ET. Errors in the calculation or estimation of the other terms affect the calculated ET and are included in the ET term.

Precipitation data $(\mathrm{P})$ were obtained from available NOAA precipitation stations in or near each watershed. Average precipitation for the watershed, where data from multiple precipitation stations were available, was estimated by using the Thiessen polygon method of areal rainfall determination (Thiessen, 1911). Streamflow data (SF) were obtained from USGS streamgages. The annual change in groundwater storage ( $\triangle$ GWS ) was estimated from water-level records for wells in the Chester County Observation Well Network (fig. 3). The annual change in groundwater storage was calculated by subtracting the December water level from the previous year's December water level, converting the difference to inches, and multiplying the result by the specific yield of the aquifer (McGreevy and Sloto, 1980, p. 18). The annual change in surface-water storage ( $\triangle \mathrm{SWS}$ ) was estimated from data provided by impoundment owners. Imported and exported water estimates were included in the ET term unless they represented more than 0.5 percent of the total water budget.

In addition, streamflow was partitioned into runoff and base flow using the local minima method of the HYSEP hydrograph-separation program (Sloto and Crouse, 1996). Base-flow yield (base flow normalized by drainage area) was calculated to remove the influence of drainage area on base flow. Base-flow yield is measured in inches and used in water budgets and in trend analysis. Linear regression was done to determine any relations of runoff and base flow to precipitation. Annual streamflow, runoff, and base flow were compared to the percentage of annual precipitation. The low threshold streamflow used in linear regressions was determined by calculating the 10-percent streamflow-duration. The low threshold value is unique for each gage and represents a streamflow that 10 percent of all recorded streamflows have been less than or equal to.

\section{Limitations}

Often, multiple influences cause changes in the hydrologic system. For example, changes in the hydrologic system may be caused by changes in climate, land use, pumping, diversions, water use, discharges, and regulation of streamflow. These changes may exert varying levels of influence at different times, either singularly or together. Although it may be possible to determine a statistically significant trend in a hydrologic variable, it may be difficult or impossible to 


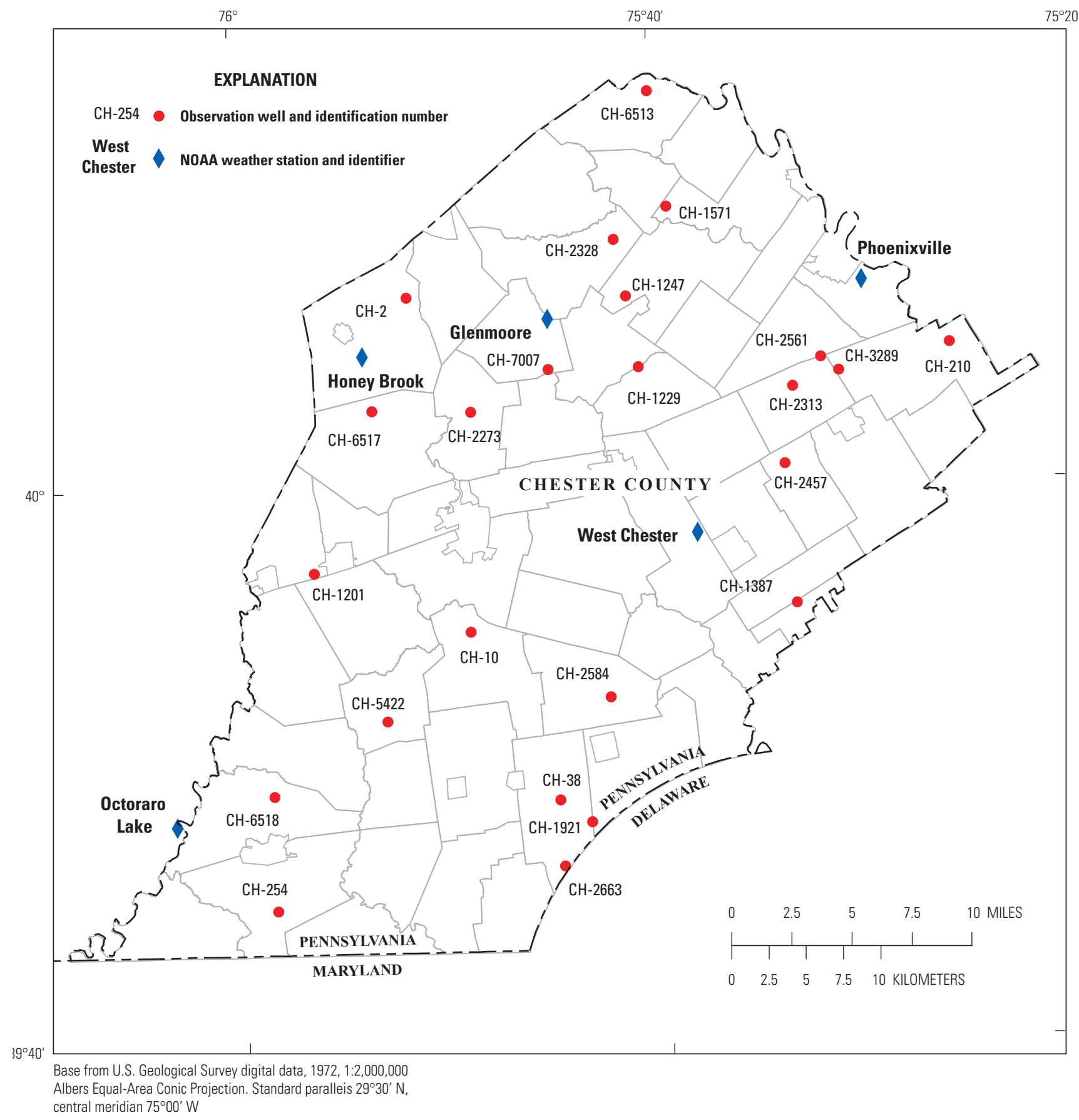

Figure 3. Location of monitoring wells in the Chester County Observation Well Network and National Oceanic and Atmospheric Administration weather stations, Chester County, Pennsylvania, and vicinity. (NOAA, National Oceanic and Atmospheric Administration)

pinpoint the exact cause or causes; thus, determining the cause of changes was beyond the scope of this report.

Many of the hydrologic and biological characteristics measured are influenced by precipitation patterns. Upward or downward trends in characteristics over short periods of time (1-5 years) may be directly related to recent precipitation patterns and are not due to long-term changes in the hydrologic system. Periods of drought or above average precipitation can cause short-term trends in hydrologic conditions that are a normal hydrologic response. Decreasing surface water and groundwater levels during 1961-65 are directly related to the unusually dry conditions that occurred during 1961-65 (fig. 4). All short-term changes in a characteristic are best viewed with the precipitation pattern during the time frame measured. 


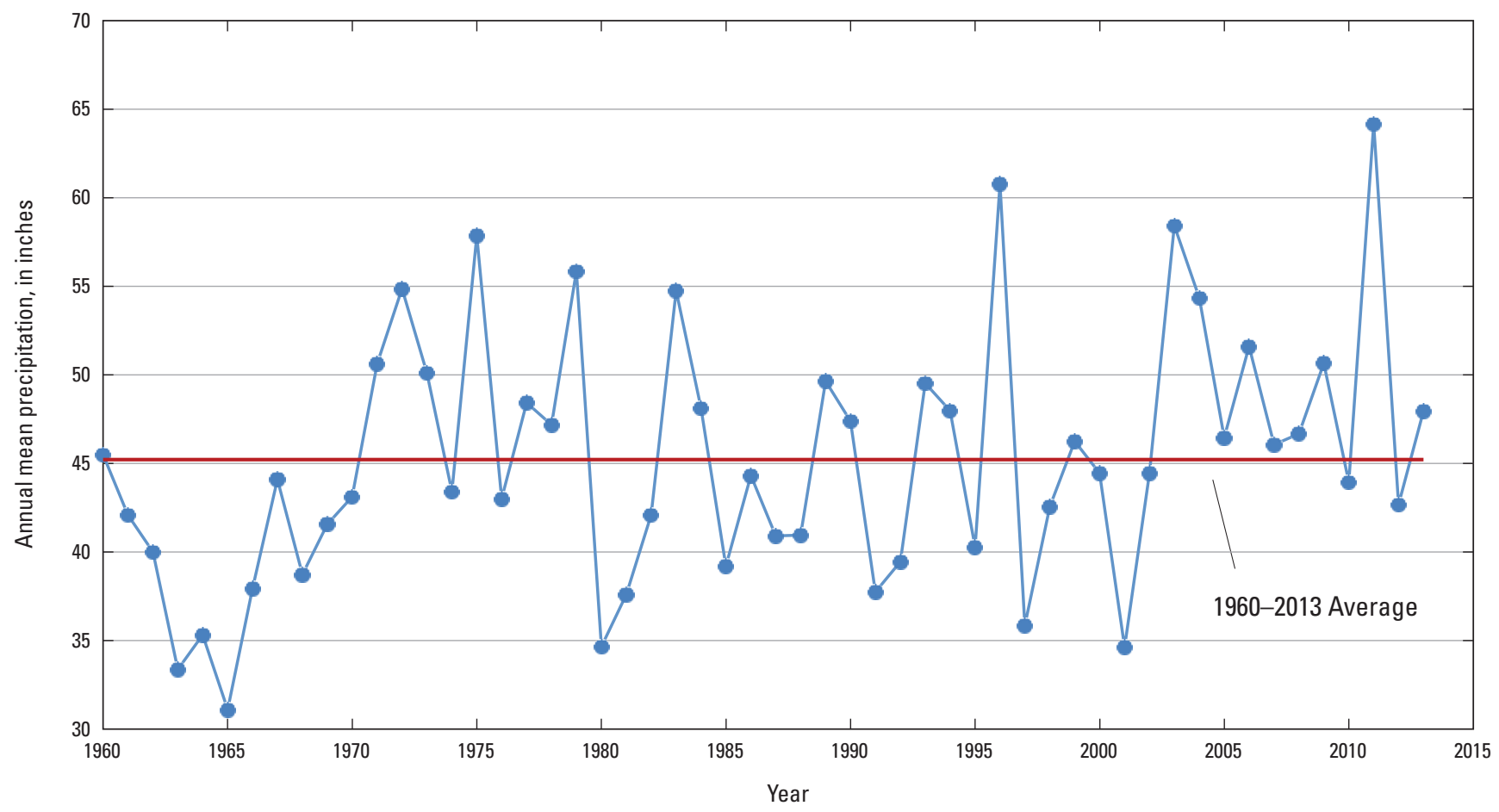

Figure 4. Annual mean precipitation in southeastern Pennsylvania from the National Oceanic and Atmospheric Administration, Southeastern Pennsylvania Piedmont Climate Division, 1960-2013.

\section{Evaluation of Long-Term Trends in Hydrologic Conditions}

Annual mean streamflow, base flow, and runoff were tested for statistically significant trends for the period of record for the 10 streamgages listed in table 1 . Other evaluations were based on tests of peak streamflow, depth to groundwater in selected monitoring wells, and meteorological data.

\section{Streamflow}

Monthly mean streamflow was tested for statistically significant trends for the period of record for the 10 streamgages in table 2 . For monthly mean streamflow, statistically significant trends occurred in July (1 station), September (1 station), October (8 stations), and December (4 stations) (table 2).

All trends were upward, except at the Big Elk streamgage (01495000) for July. The greatest increase in monthly mean streamflow was for Brandywine Creek at Chadds Ford, Pa. (01481000) for December where the increase in streamflow was $47 \mathrm{ft}^{3} / \mathrm{s}$ per decade (fig. 5). This represents an increase in December streamflow at Brandywine Creek at Chadds Ford, Pa. (01481000) of approximately 10 percent every decade. The only statistically significant trend for annual mean streamflow was at West Branch Brandywine Creek near Honey Brook, Pa. (01480300), which exhibited an upward trend for streamflow $(p=0.044$, slope $=0.163)$ over the period of record 1961-2013 (fig. 6). Annual mean streamflow increased 1.6 cubic feet per second $\left(\mathrm{ft}^{3} / \mathrm{s}\right)$ per decade.

\section{Base Flow}

Monthly mean base flow was tested for statistically significant trends for the period of record, 1933-2013, for the streamgages in table 2 . For monthly mean base flow, statistically significant trends occurred in July (1 station), October (3 stations), November (2 stations), and December (3 stations) (table 2). The trend was upward for all stations, except at West Branch Brandywine Creek at Modena, Pa. (01480617) for July. The greatest increase in monthly mean base flow was for Brandywine Creek at Chadds Ford, Pa. (01481000) for December (fig. 7) where the increase in base flow was $26 \mathrm{ft}^{3} / \mathrm{s}$ per decade.

Annual base-flow yield was calculated so that annual base flow could be compared among watersheds. The normalized annual mean base flow and the 1-in-25-year base flow statistic were calculated for the streamgages in table 3. The 1-in25-year base-flow statistic represents base-flow conditions that have a 4 percent (or 1 in 25) chance of occurring during any year. The normalized annual mean base flow ranged from 11.1 inches for West Branch Brandywine Creek near Honey Brook, Pa. (01480300) and West Branch Brandywine Creek at Coatesville (01480500) to 14.9 inches for East Branch 
Table 1. Kendall p-values for annual mean streamflow, base flow, and runoff at 10 streamgages in Chester County, Pennsylvania, and Cecil County, Maryland.

[USGS, U.S. Geological Survey; shading indicates statistically significant trend; trends were considered significant if the p-value was less than 0.05; p-value measures the significance of the trend, the lower the p-value, the greater the statistical significance]

\begin{tabular}{|c|c|c|c|c|c|c|}
\hline \multirow{2}{*}{$\begin{array}{c}\text { USGS } \\
\text { streamgage } \\
\text { number }\end{array}$} & \multirow{2}{*}{ Streamgage name } & \multirow{2}{*}{$\begin{array}{l}\text { Period of } \\
\text { record }\end{array}$} & \multirow{2}{*}{$\begin{array}{l}\text { Years of } \\
\text { record }\end{array}$} & \multicolumn{3}{|c|}{ Kendall p-value } \\
\hline & & & & $\begin{array}{c}\text { Stream- } \\
\text { flow }\end{array}$ & Base flow & Runoff \\
\hline 01472157 & French Creek near Phoenixville, Pa. & $1969-2013$ & 45 & 0.660 & 0.717 & 0.674 \\
\hline 01480300 & West Branch Brandywine Creek near Honey Brook, Pa. & $1961-2013$ & 53 & 0.044 & 0.061 & 0.074 \\
\hline 01480500 & West Branch Brandywine Creek at Coatesville, $\mathrm{Pa}$. & $1971-2013$ & 43 & 0.445 & 0.267 & 0.722 \\
\hline 01480617 & West Branch Brandywine Creek at Modena, $\mathrm{Pa}$. & $1970-2013$ & 44 & 0.379 & 0.413 & 0.413 \\
\hline 01480870 & East Branch Brandywine Creek below Downingtown, Pa. & $1973-2013$ & 41 & 0.703 & 0.567 & 0.814 \\
\hline 01481000 & Brandywine Creek at Chadds Ford, Pa. & $1963-2013$ & 51 & 0.123 & 0.111 & 0.139 \\
\hline 01495000 & Big Elk Creek at Elk Mills, Md. & $1933-2013$ & 81 & 0.785 & 0.365 & 0.517 \\
\hline
\end{tabular}

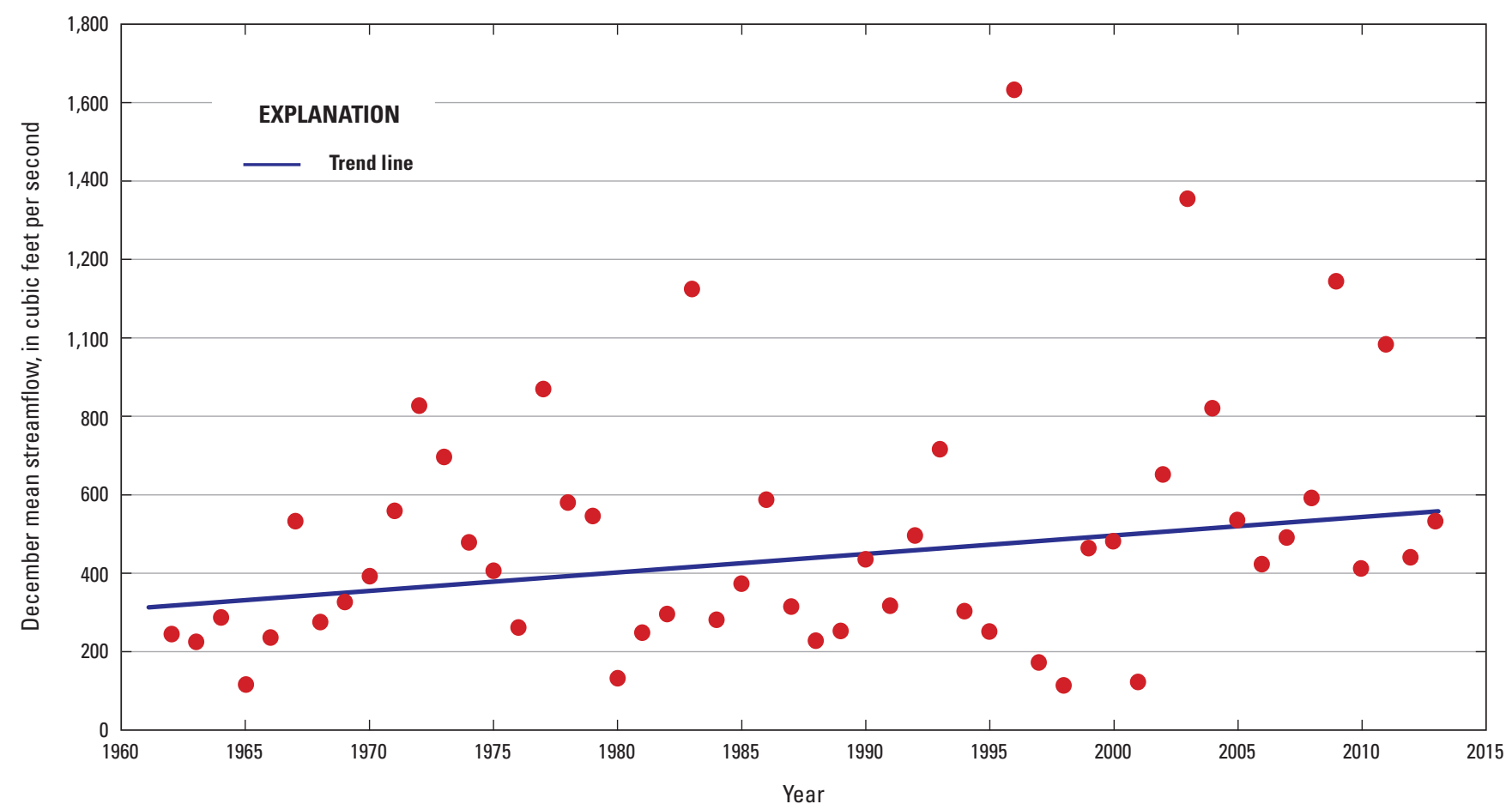

Figure 5. December mean streamflow at streamgage 01481000 Brandywine Creek at Chadds Ford, Pennsylvania, 1962-2013. 


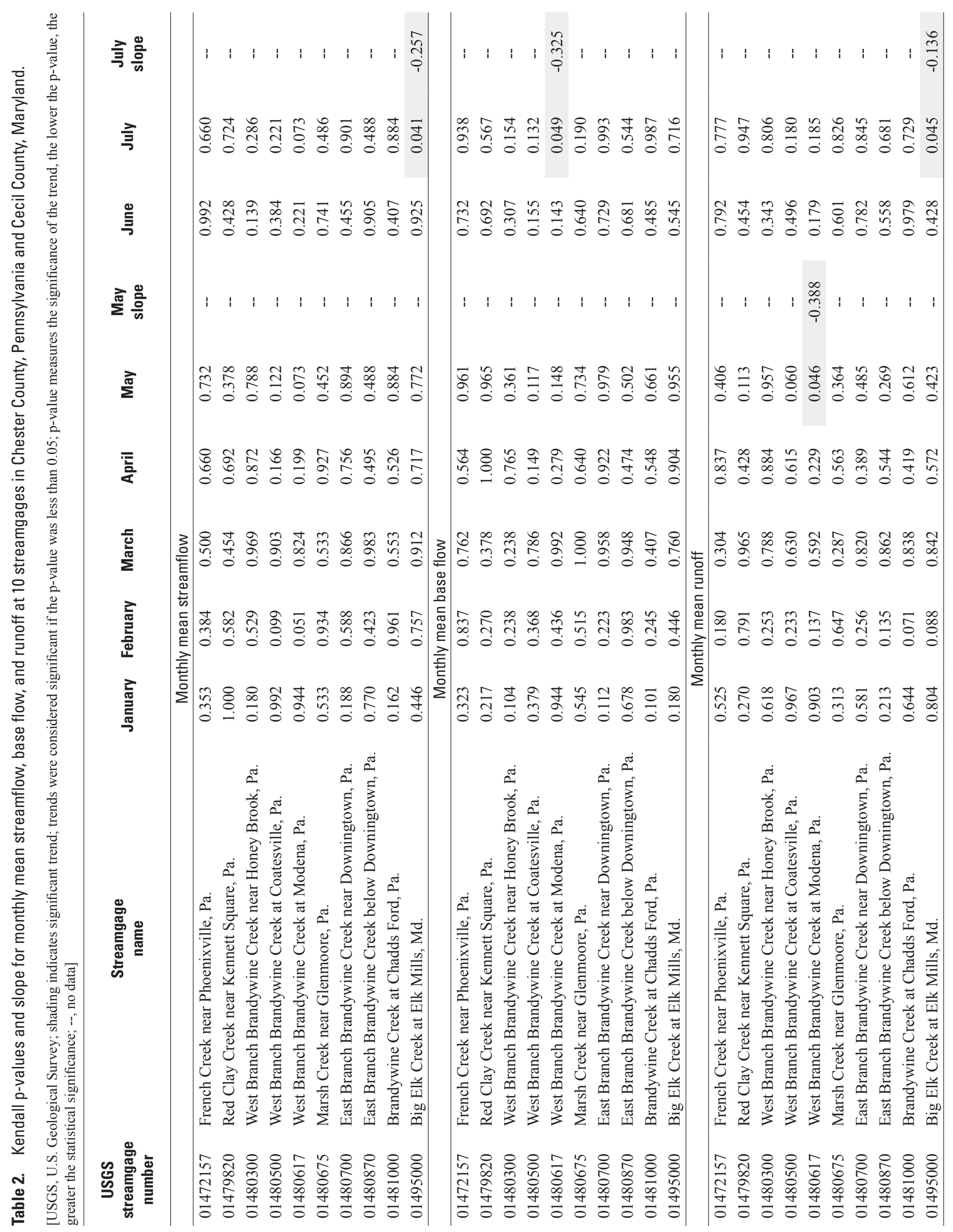




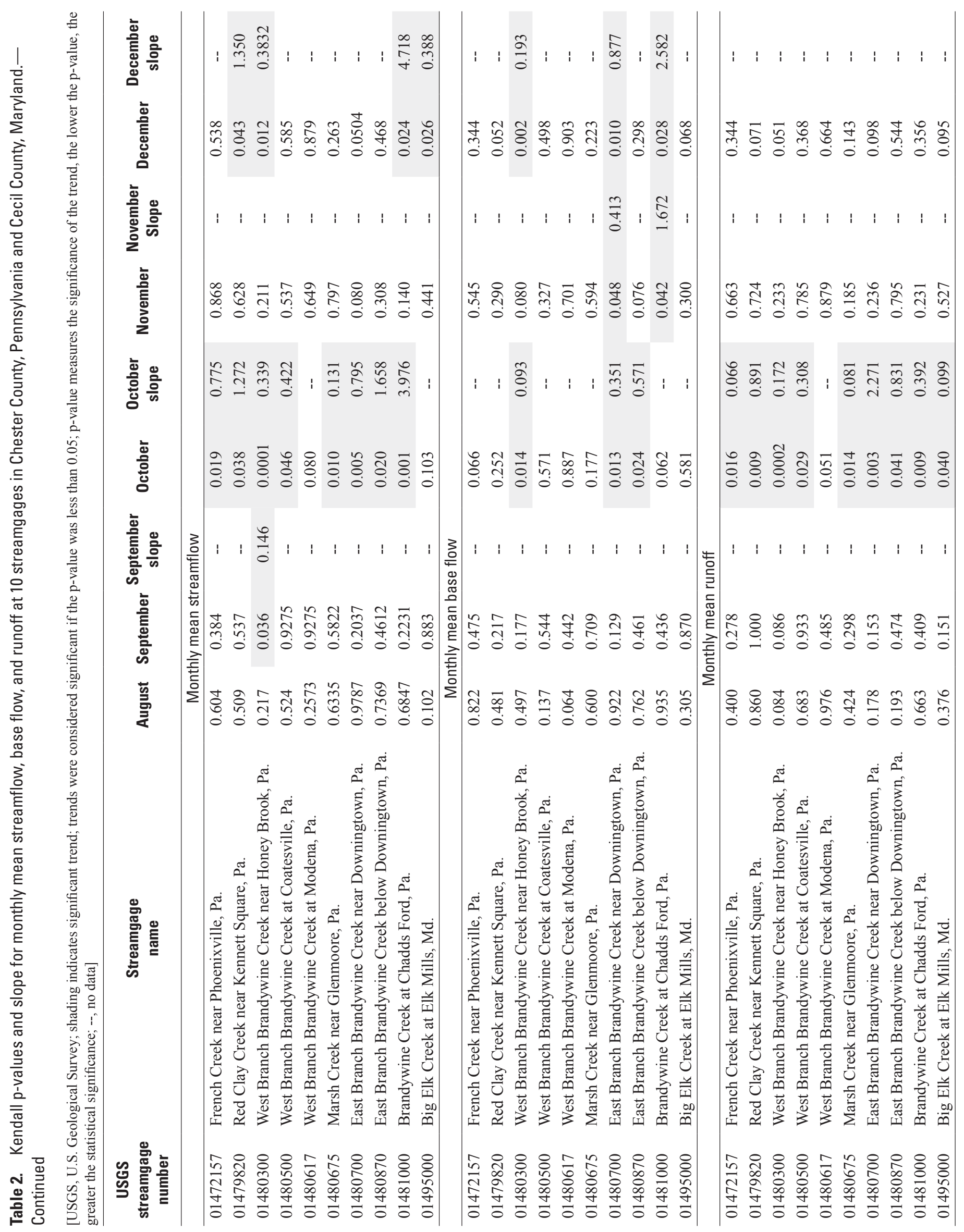


Trends in Hydrologic and Water-Quality Conditions, and Estimation of Water Budgets Through 2013, Chester County, Pa.

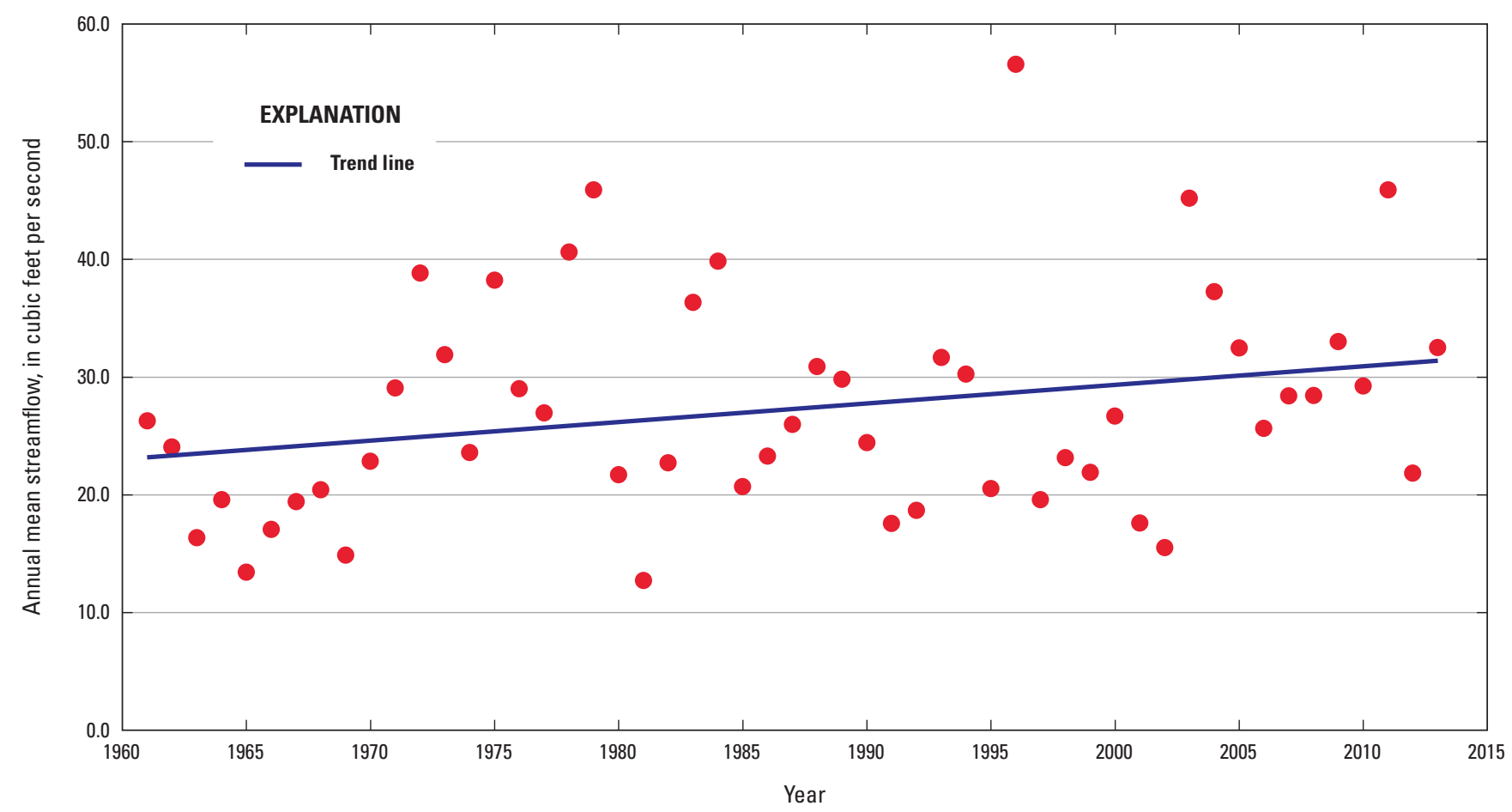

Figure 6. Annual mean streamflow at streamgage 01480300, West Branch Brandywine Creek near Honey Brook, Pennsylvania, 1961-2013.

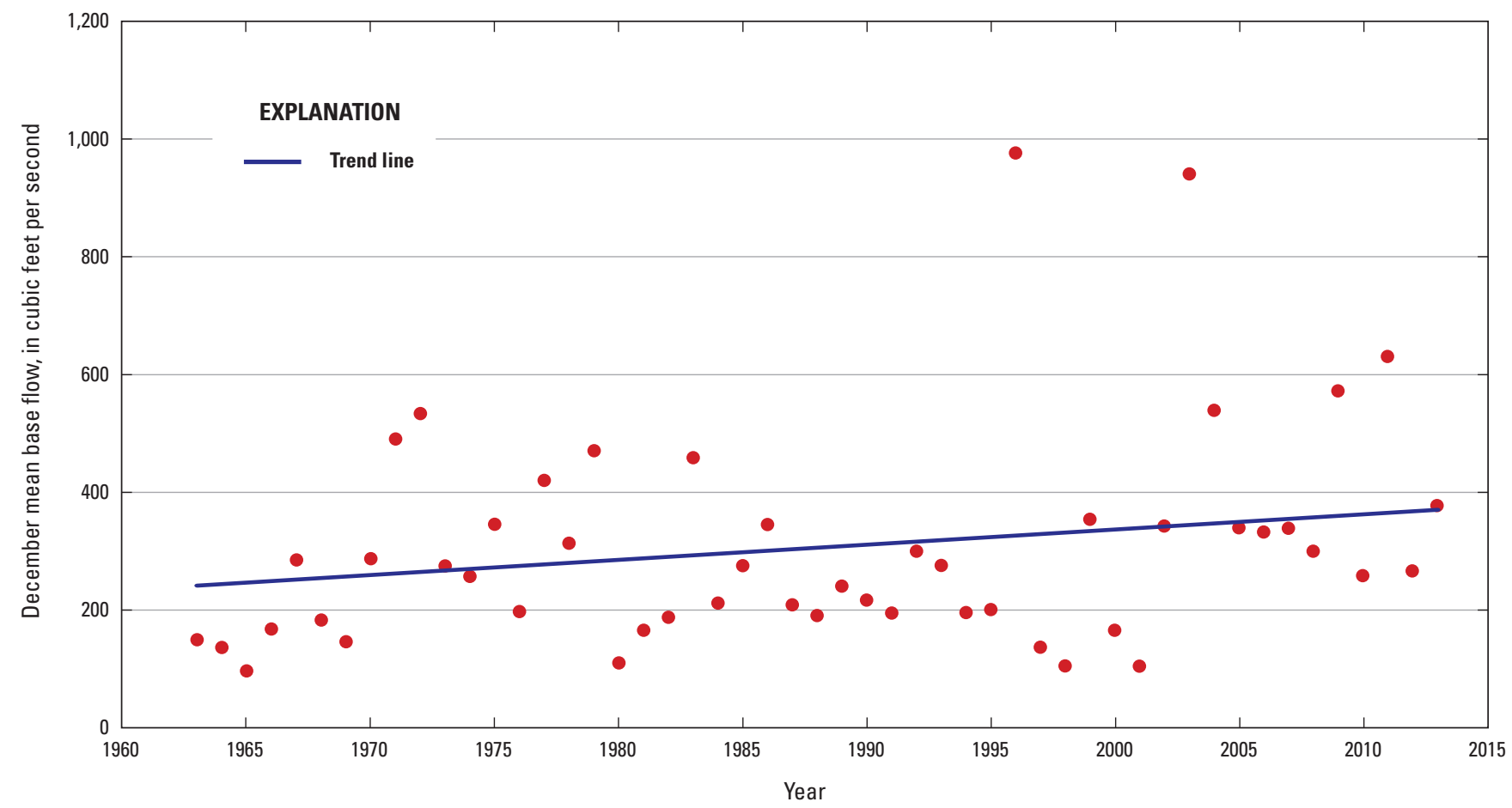

Figure 7. December mean base flow at streamgage 01481000, Brandywine Creek at Chadds Ford, Pennsylvania, $1963-2013$. 
Table 3. Normalized mean annual base flow and 1-in-25-year base flow at 10 streamgages in Chester County, Pennsylvania, and Cecil County, Maryland.

[USGS, U.S. Geological Survey; Base-flow values given in inches; $\mathrm{mi}^{2}$, square miles]

\begin{tabular}{|c|c|c|c|c|}
\hline $\begin{array}{c}\text { USGS } \\
\text { streamgage } \\
\text { number }\end{array}$ & Streamgage name & $\begin{array}{c}\text { Drainage } \\
\text { area } \\
\left(\mathrm{mi}^{2}\right)\end{array}$ & $\begin{array}{c}\text { Normalized } \\
\text { mean annual } \\
\text { base flow }\end{array}$ & $\begin{array}{c}\text { 1-in-25-year } \\
\text { base flow }\end{array}$ \\
\hline 01472157 & French Creek near Phoenixville, $\mathrm{Pa}$. & 59.1 & 12.9 & 6.1 \\
\hline 01479820 & Red Clay Creek near Kennett Square, Pa. & 28.3 & 13.3 & 7.6 \\
\hline 01480500 & West Branch Brandywine Creek at Coatesville, Pa. & 45.8 & 11.1 & 5.3 \\
\hline 01480617 & West Branch Brandywine Creek at Modena, Pa. & 55.0 & 13.1 & 7.1 \\
\hline 01480675 & Marsh Creek near Glenmoore, Pa. & 8.6 & 11.5 & 5.7 \\
\hline 01481000 & Brandywine Creek at Chadds Ford, Pa. & 287 & 13.3 & 6.7 \\
\hline 01495000 & Big Elk Creek at Elk Mills, Md. & 51.6 & 11.6 & 6.1 \\
\hline
\end{tabular}

Brandywine Creek below Downingtown, Pa. (01480870). The 1-in-25-year base flow ranged from 5.3 inches at West Branch Brandywine Creek at Coatesville, Pa. (01480500) to 8.2 inches at East Branch Brandywine Creek below Downingtown, Pa. (01480870).

\section{Runoff}

Monthly mean runoff was analyzed for statistically significant trends for the period of record for the streamgages listed in table 2 . For monthly mean runoff, statistically significant trends occurred in May (1 station), July (1 station), and October (8 stations) (table 2). The trend was upward for all stations, except for West Branch Brandywine Creek at Modena, Pa. (01480617) for May and Big Elk Creek at Elk Mills, Maryland (01495000) for July. The greatest increase in monthly mean runoff was for East Branch Brandywine Creek near Downingtown, Pa. (01480700) for October (fig. 8) where the increase in runoff was $2.3 \mathrm{ft}^{3} / \mathrm{s}$ per decade.

\section{Peak Streamflow}

The term "peak above base" is intended to identify a large streamflow that exceeds a specified "base" streamflow that occurs on an average of three times a year at a streamgage. Though typically used for streams not subject to substantial control (Novak, 1985), the additional published peaks that occur for even part of the period of record are valuable for peak-flow analysis. The magnitude of annual peak flows and, when available peaks above the base, were tested for statistically significant trends using the Kendall's rank correlation test for the period of record for the streamgages listed in table 4. Fifty percent of the streamgages showed a statistically significant increase in the number of peaks above the base (or annual peaks) for the period of record. Although the increase in peak streamflow above the base was significant, it is small. The greatest increase in peak streamflow was for Brandywine Creek at Chadds Ford, Pa. (01481000) for 1962-2012 (fig. 9). The increase in peak streamflow was $1.9 \mathrm{ft}^{3} / \mathrm{s}$ per decade.

The frequency and number of floods equal to or greater than the 2-year recurrence interval (for this report considered to be approximate bank full flow) were tested for statistically significant trends for the period of record for the streamgages in table 5. There were no statistically significant trends for the magnitude of peak streamflow equal to or greater than the 2-year recurrence interval or for the number of annual peak streamflows equal to or greater than the 2-year recurrence interval (table 5). In fact, there was no statistically significant trend in the number of streamflows equal to or greater than the 2-year-recurrence interval (streamflow) (table 5, fig. 10) or the magnitude of streamflow equal to or greater than the 2-yearrecurrence interval (streamflow) (table 5, fig. 11).

\section{Groundwater Levels}

The Chester County Observation Well Network was established by the CCWRA and the USGS in 1973. Monthly groundwater levels have been measured in the network since 


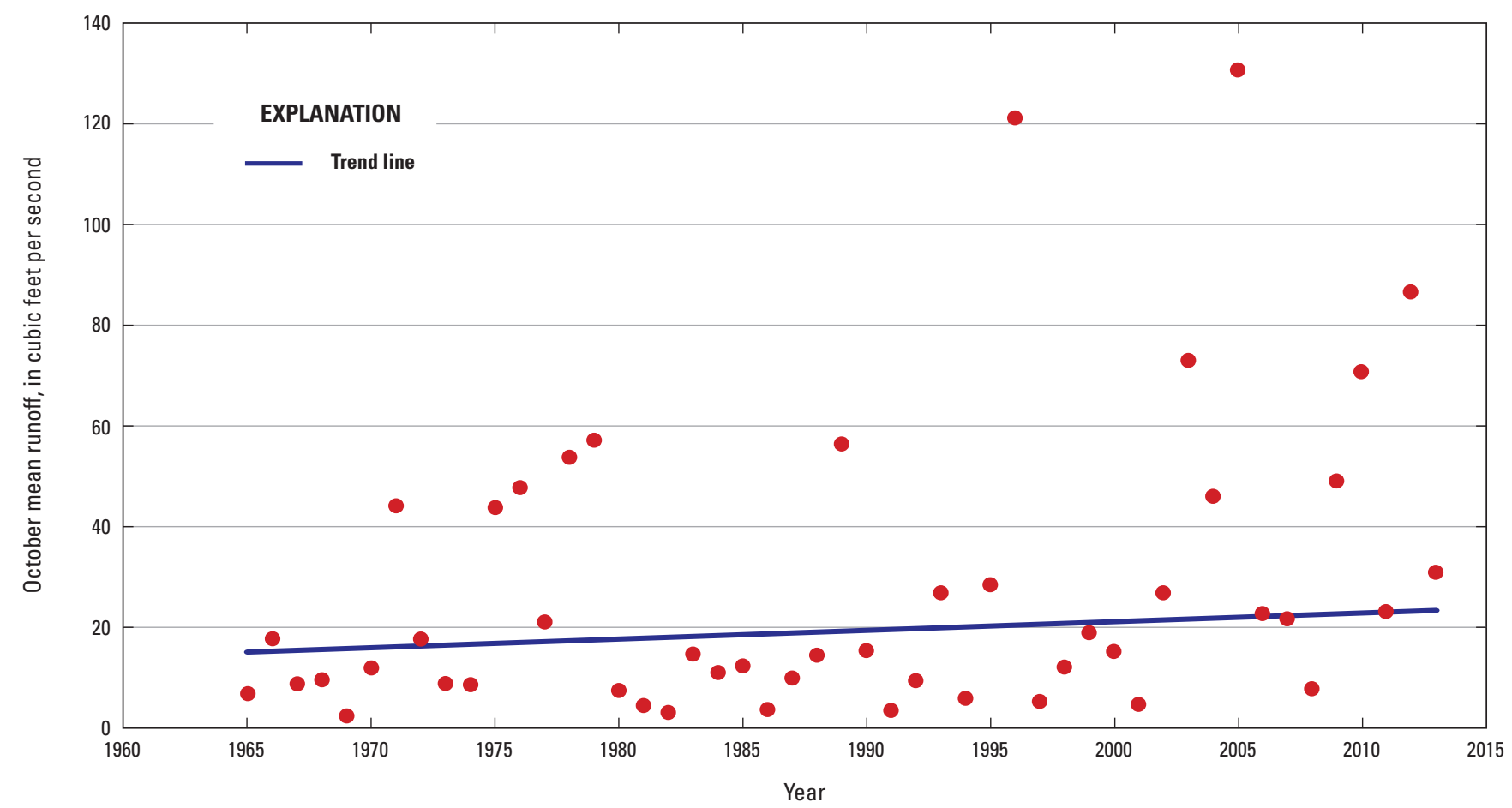

Figure 8. October mean runoff at streamgage 01480700, East Branch Brandywine Creek near Downingtown, Pennsylvania, $1965-2013$.

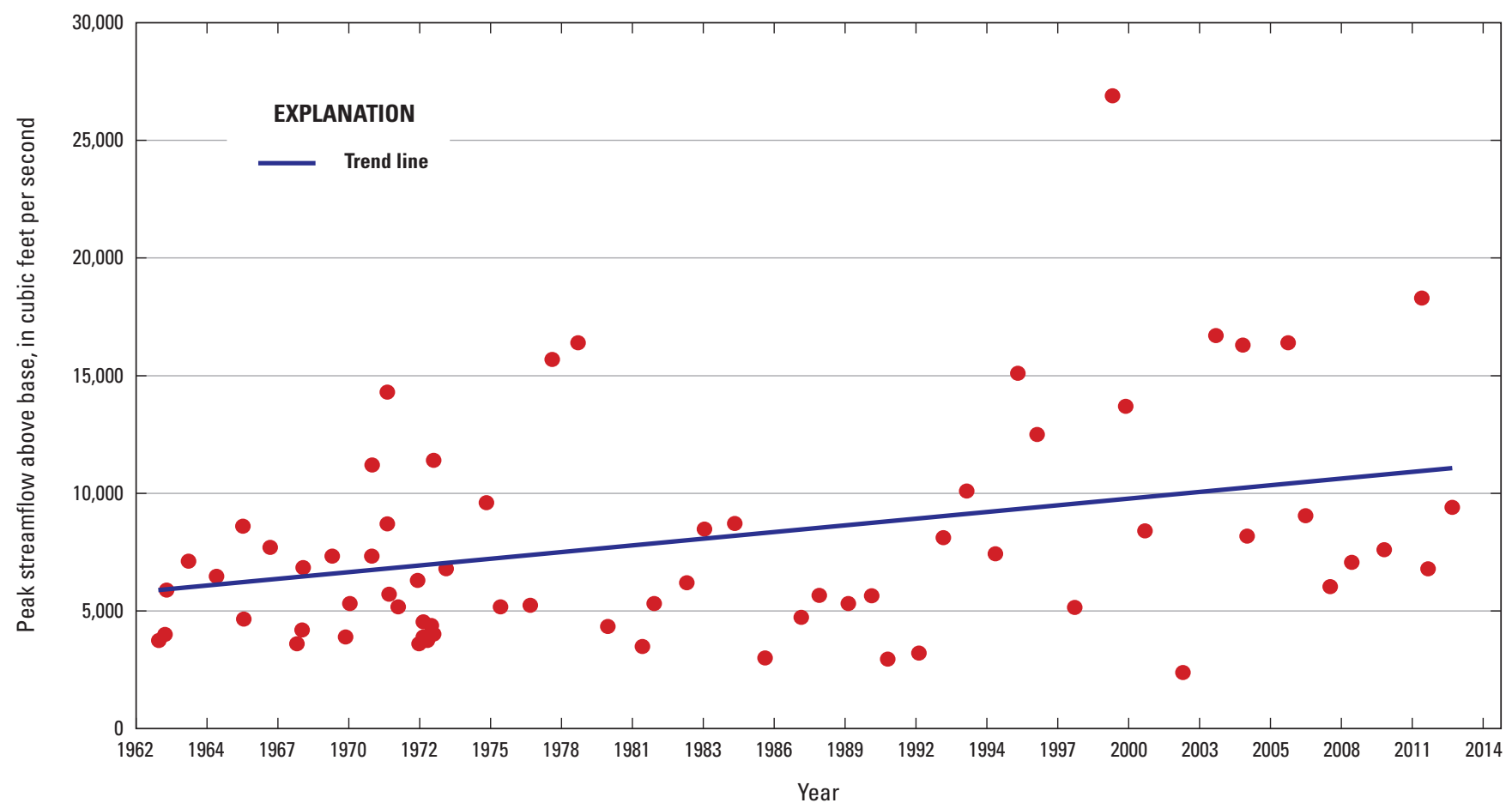

Figure 9. Peak streamflow above a base streamflow of 3,500 cubic feet per second at streamgage 01481000, Brandywine Creek at Chadds Ford, Pennsylvania, 1962-2012. 
Table 4. Kendall p-values for trends in peak streamflow above base streamflow at 12 streamgages in Chester County, Pennsylvania and Cecil County, Maryland.

[USGS, U.S. Geological Survey; $\mathrm{ft}^{3} / \mathrm{s}$, cubic feet per second; The term "peak above base" is intended to identify a large streamflow that exceeds a specified "base" streamflow that occurs on an average of three times a year at a streamgage; --, slope not significant; shading indicates significant trend; trends were considered significant if the p-value was less than 0.05 ; $\mathrm{p}$-value measures the significance of the trend, the lower the p-value, the greater the statistical significance]

\begin{tabular}{|c|c|c|c|c|c|c|}
\hline $\begin{array}{c}\text { USGS } \\
\text { streamgage } \\
\text { number }\end{array}$ & Streamgage name & $\begin{array}{c}\text { Period } \\
\text { evaluated }\end{array}$ & $\begin{array}{c}\text { Number of } \\
\text { peaks above } \\
\text { base stream- } \\
\text { flow }\end{array}$ & $\begin{array}{c}\text { Base } \\
\text { streamflow } \\
\left(\mathrm{ft}^{3} / \mathrm{s}\right)\end{array}$ & $\begin{array}{c}\text { p-value } \\
\text { for peak } \\
\text { streamflow }\end{array}$ & Slope \\
\hline 01472157 & French Creek near Phoenixville, Pa. & 1969-2012 & 226 & 1,000 & 0.001 & 0.026 \\
\hline 01473169 & Valley Creek at PA Turnpike Bridge near Valley Forge, Pa. & $1983-2013$ & 145 & 600 & 0.956 & -- \\
\hline 01480300 & West Branch Brandywine Creek near Honey Brook, Pa. & 1960-2012 & 224 & 500 & 0.026 & 0.008 \\
\hline 01480500 & West Branch Brandywine Creek at Coatesville, Pa. & 1970-2012 & 204 & 700 & 0.303 & -- \\
\hline 01480700 & East Branch Brandywine Creek near Downingtown, Pa. & $1966-2011$ & 77 & ${ }^{2} 900$ & 0.002 & 0.083 \\
\hline 01480870 & East Branch Brandywine Creek below Downingtown, Pa. & $1972-2011$ & 54 & ${ }^{2} 1,200$ & 0.000 & 0.182 \\
\hline 01480638 & Broad Run at Northbrook, Pa. & 2004-2011 & 30 & 170 & 0.858 & -- \\
\hline 01481000 & Brandywine Creek at Chadds Ford, Pa. & ${ }^{1} 1912-2012$ & 217 & 23,500 & 0.002 & 0.050 \\
\hline 01481000 & Brandywine Creek at Chadds Ford, Pa. & $1962-2012$ & 69 & 23,500 & 0.012 & 0.189 \\
\hline 01495000 & Big Elk Creek at Elk Mills, Md. & $1932-2013$ & 223 & 1,700 & 0.586 & -- \\
\hline
\end{tabular}

${ }^{1}$ Gap in record.

${ }^{2}$ Base streamflow determined prior to regulation from Marsh Creek Reservoir.

1973 (table 6, fig. 3). In addition, daily groundwater level data are available for well CH-10 from August 1951 to 2015. The maximum water level for $\mathrm{CH}-10$ measured on the same day that water levels in the Chester County Observation Well Network were measured was chosen to represent monthly data. Wells with short periods of records, wells that periodically went dry, wells with records affected by quarry pumping, and wells with missing data were not evaluated.

Annual mean water level, annual minimum water level, annual maximum water level, and annual range of water-level fluctuations were evaluated for statistically significant trends. For water-level data, a negative slope indicates an upward trend, or increasing water level (table 7), because water levels are plotted on a reversed Y-axis with water level below land surface decreasing from the bottom to the top of the Y-axis. Four wells (CH-10, CH-1201, CH-1387, and CH-2457) exhibited a small statistically significant increase in annual mean water level; no wells showed a statistically significant decrease in annual mean water level (table 7). Increases in annual mean water level ranged from 0.16 foot $(\mathrm{ft})$ per decade for well $\mathrm{CH}-1201$ to $0.74 \mathrm{ft}$ per decade for well $\mathrm{CH}-2457$. Well $\mathrm{CH}-10$ with a period of record spanning 62 years (1951-2013) exhibited a small statistically significant upward trend in annual mean water level of $0.22 \mathrm{ft}$ per decade (fig. 12). In addition, well $\mathrm{CH}-10$ was the only well to exhibit a statistically significant increase in the annual range of water-level fluctuations (fig. 13). The annual range of water-level fluctuations is the difference between the annual maximum water-level and the annual minimum water-level. The increase in the annual range in fluctuation was $1.1 \mathrm{ft}$ over the period of record.

Two wells exhibited statistically significant trends in the annual maximum water level (table 7). Well $\mathrm{CH}-10$ exhibited an upward trend, whereas well $\mathrm{CH}-2273$ exhibited a downward trend. Three wells (CH-1201, CH-1387, and CH-2457) showed a statistically significant upward trend in annual minimum water level.

Monthly mean water levels were evaluated for statistically significant trends (table 8). The greatest monthly trend 
Table 5. Kendall p-values for trends in peak streamflow and number of peak streamflows equal to or greater than the 2-year recurrence interval at 11 streamgages in Chester County, Pennsylvania, and Cecil County, Maryland.

[USGS, U.S. Geological Survey; $\mathrm{ft}^{3} / \mathrm{s}$, cubic feet per second; trends were considered significant if the p-value was less than 0.05; p-value measures the significance of the trend, the lower the p-value, the greater the statistical significance]

\begin{tabular}{|c|c|c|c|c|c|c|}
\hline $\begin{array}{c}\text { USGS } \\
\text { streamgage } \\
\text { number }\end{array}$ & Streamgage name & $\begin{array}{c}\text { 2-year } \\
\text { peak } \\
\text { stream- } \\
\text { flow } \\
\left(\mathrm{ft}^{3} / \mathrm{s}\right)\end{array}$ & $\begin{array}{c}\text { Period } \\
\text { evaluated }\end{array}$ & $\begin{array}{l}\text { Number } \\
\text { of peaks } \\
\text { equal to } \\
\text { or greater } \\
\text { than 2-year } \\
\text { streamflow }\end{array}$ & $\begin{array}{l}\text { p-value for } \\
\text { peak dis- } \\
\text { charge equal } \\
\text { to or greater } \\
\text { than 2-year } \\
\text { streamflow }\end{array}$ & $\begin{array}{c}\text { p-value for } \\
\text { number of } \\
\text { peaks per } \\
\text { year equal } \\
\text { to or greater } \\
\text { than 2-year } \\
\text { streamflow }\end{array}$ \\
\hline 01473169 & Valley Creek at PA Turnpike Bridge near Valley Forge, Pa. & 1,314 & 1989-2013 & 23 & 0.579 & 0.496 \\
\hline 01479820 & Red Clay Creek near Kennett Square, Pa. & 1,985 & 1989-2011 & 21 & 0.277 & 0.778 \\
\hline 01480300 & West Branch Brandywine Creek near Honey Brook, Pa. & 1,304 & 1960-2011 & 43 & 0.660 & 0.083 \\
\hline 01480500 & West Branch Brandywine Creek at Coatesville, Pa. & 1,902 & ${ }^{1} 1942-2011$ & 44 & 0.206 & 0.680 \\
\hline 01480700 & East Branch Brandywine Creek near Downingtown, Pa. & 2,382 & 1966-2011 & 27 & 0.967 & 0.334 \\
\hline 01480870 & East Branch Brandywine Creek below Downingtown, Pa. & 3,548 & $1972-2011$ & 21 & 0.215 & 0.396 \\
\hline 01481000 & Brandywine Creek at Chadds Ford, Pa. & 7,065 & ${ }^{2} 1912-2012$ & 55 & 0.135 & 0.585 \\
\hline 01495000 & Big Elk Creek at Elk Mills, Maryland, Md. & 2,900 & $1932-2013$ & 70 & 0.881 & 0.822 \\
\hline
\end{tabular}

'Period of record for streamgage 01480500; October 1943 to December 1951, January 1970 to 2011.

${ }^{2}$ Period of record for gage 01481000; August 1911 to September 1953, October 1962 to 2011.

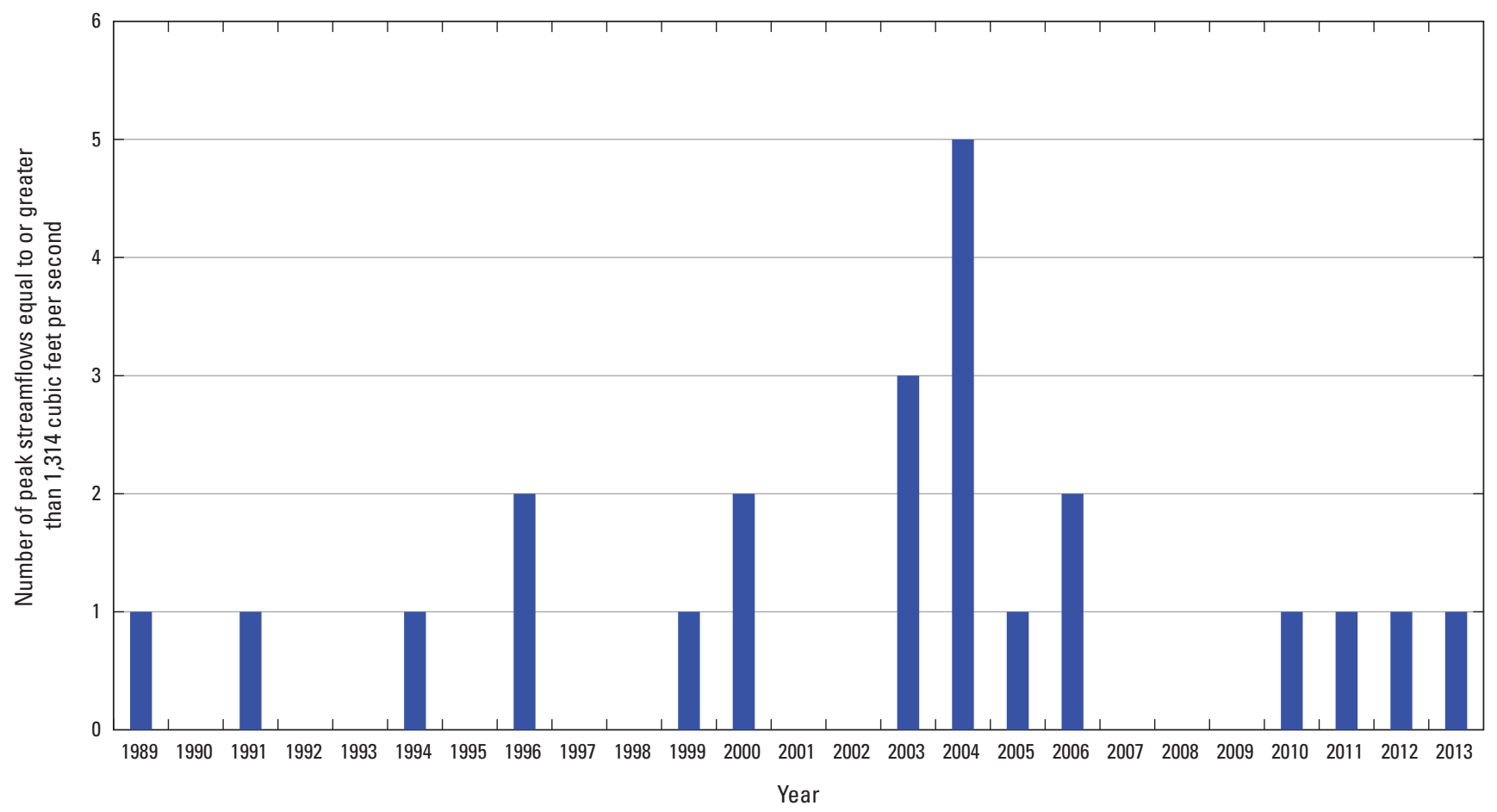

Figure 10. Number of annual peak streamflows equal to or greater than the 2-year recurrence interval at streamgage 01473169, Valley Creek at Pennsylvania Turnpike Bridge near Valley Forge, Pennsylvania, 1989-2013. 


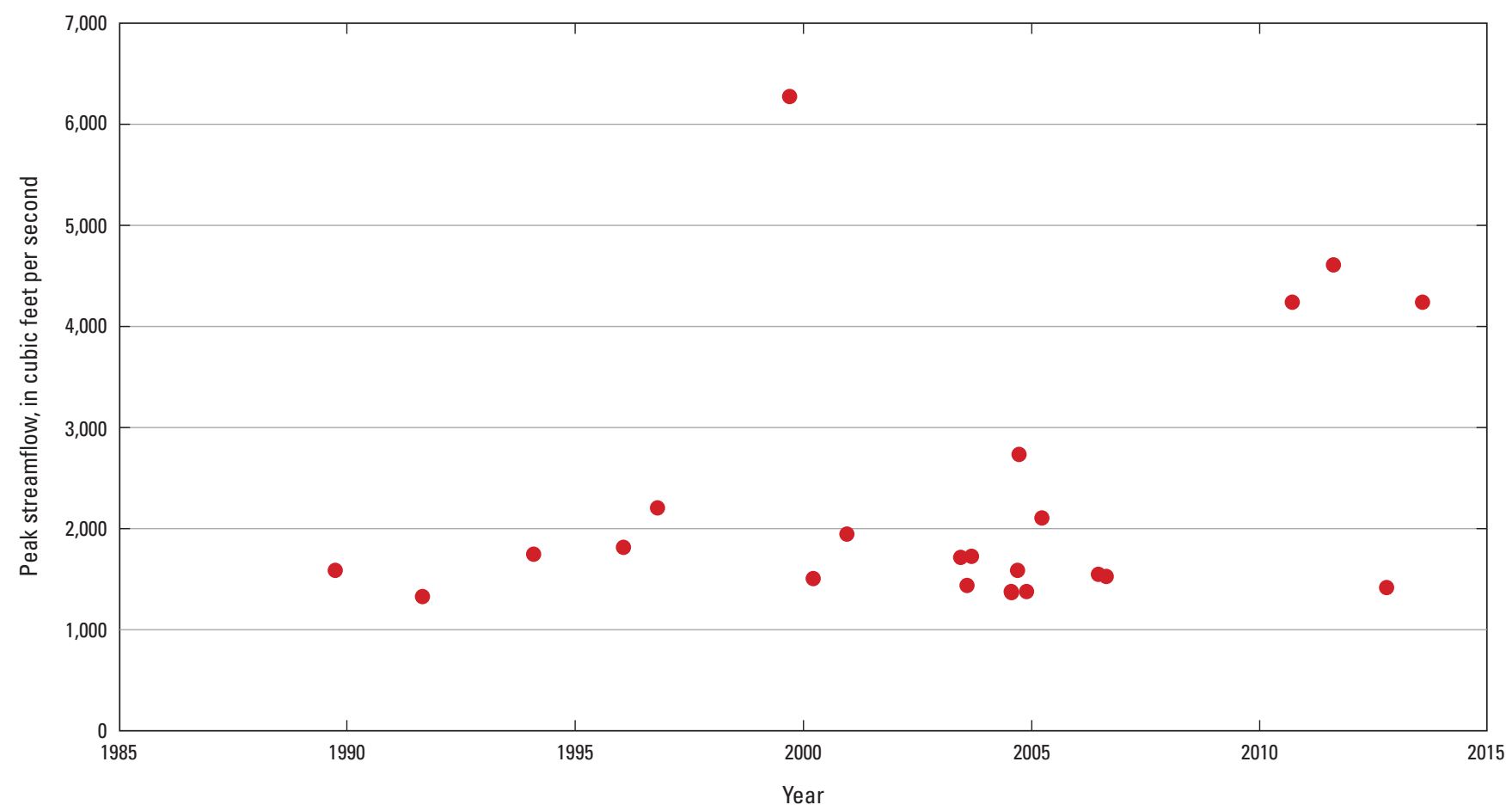

Figure 11. Peak streamflow equal to or greater than the 2-year recurrence interval at streamgage 01473169, Valley Creek at Pennsylvania Turnpike Bridge near Valley Forge, Pennsylvania, 1989-2013.

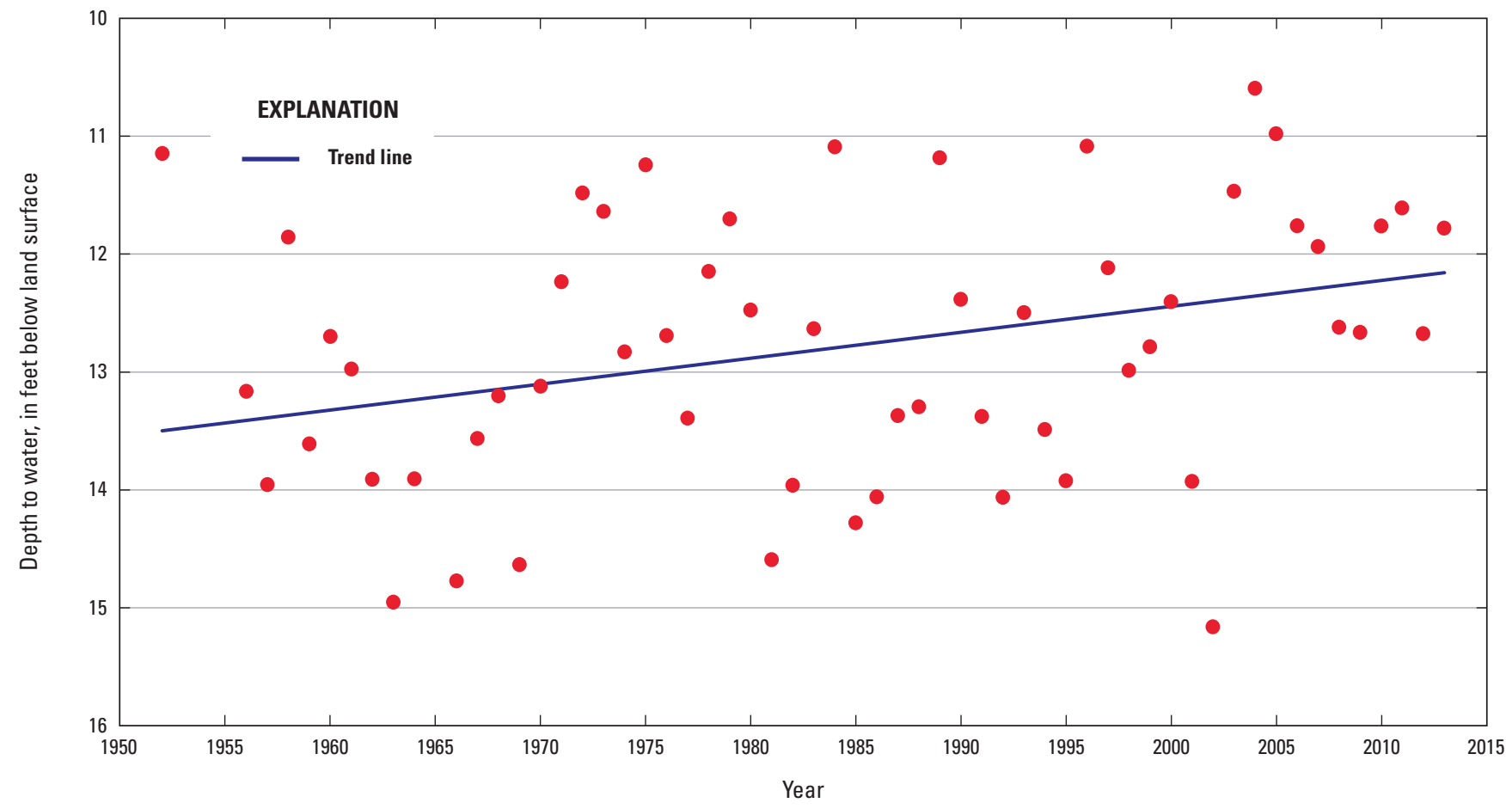

Figure 12. Annual mean water level in well CH-10, Chester County, Pennsylvania, 1952-2013. 
Table 6. Monitoring wells in the Chester County Observation Well Network in Pennsylvania used for statistical analysis.

[USGS, U.S. Geological Survey; --, depth not known; Pa. Pennsylvania]

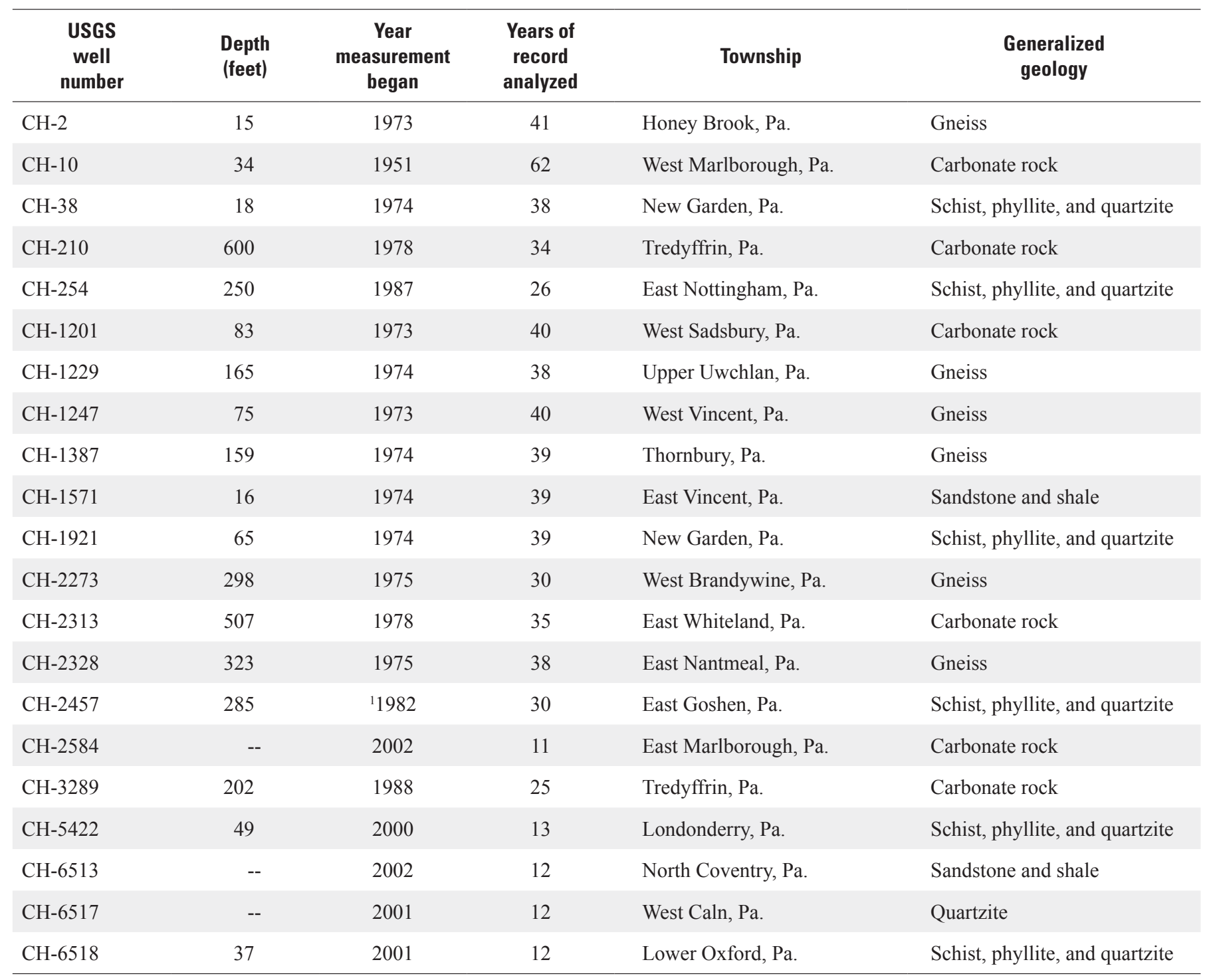

${ }^{1}$ Early period of record affected by pumping. Post-pumping measurements analyzed beginning in January 1984.

was for well CH-6513, which showed a decrease in the November mean water level of 0.37 feet per year (fig. 14). However, well CH-6513 has a relatively short period of record (2002-13). The water level in well CH-6513 exhibited a downward trend in water level in the late fall and early winter (November, December, and January). The water level in well CH-2313 exhibited a downward trend in water level in late spring and summer (May, June, July, and August).

Linear regression was used to determine whether a relation exists between annual mean groundwater levels and annual mean streamflow and base flow at a nearby streamgage (table 9). The correlation coefficient $\left(\mathrm{r}^{2}\right)$ values for the correlation between annual mean groundwater levels and annual mean streamflow and base flow range from 0.005 to 0.818 . Groundwater levels correlated better with base flow than streamflow, likely because base flow is the discharge of groundwater to streams. For base flow, log-transformed data correlated better than non-transformed data (table 9), indicating a non-linear relation. Eleven of the 21 log-transformed base-flow correlations had an $\mathrm{r}^{2}$ greater than 0.7 . The best correlation of annual mean groundwater level with annual mean streamflow was for the log transformed data for well CH-3289 and streamflow at French Creek near Phoenixville, Pa. (01472157) $\left(\mathrm{r}^{2}=0.679\right.$, fig. 15). The best correlation of annual mean groundwater level with annual mean base flow was for the water level in well CH-5422 and base flow at West Branch Brandywine Creek at Modena, Pa. (01480617) $\left(\mathrm{r}^{2}=0.818\right.$, fig. 16).

Linear regression was used to determine whether a relation exists between annual mean groundwater level and 
Table 7. Kendall p-values for trends in annual mean groundwater levels in monitoring wells in the Chester County Observation Well Network, Pennsylvania.

[USGS, U.S. Geological Survey; --, slope not significant; shading indicates significant trend; trends were considered significant if the p-value was less than 0.05; $\mathrm{p}$-value measures the significance of the trend, the lower the $\mathrm{p}$-value, the greater the statistical significance]

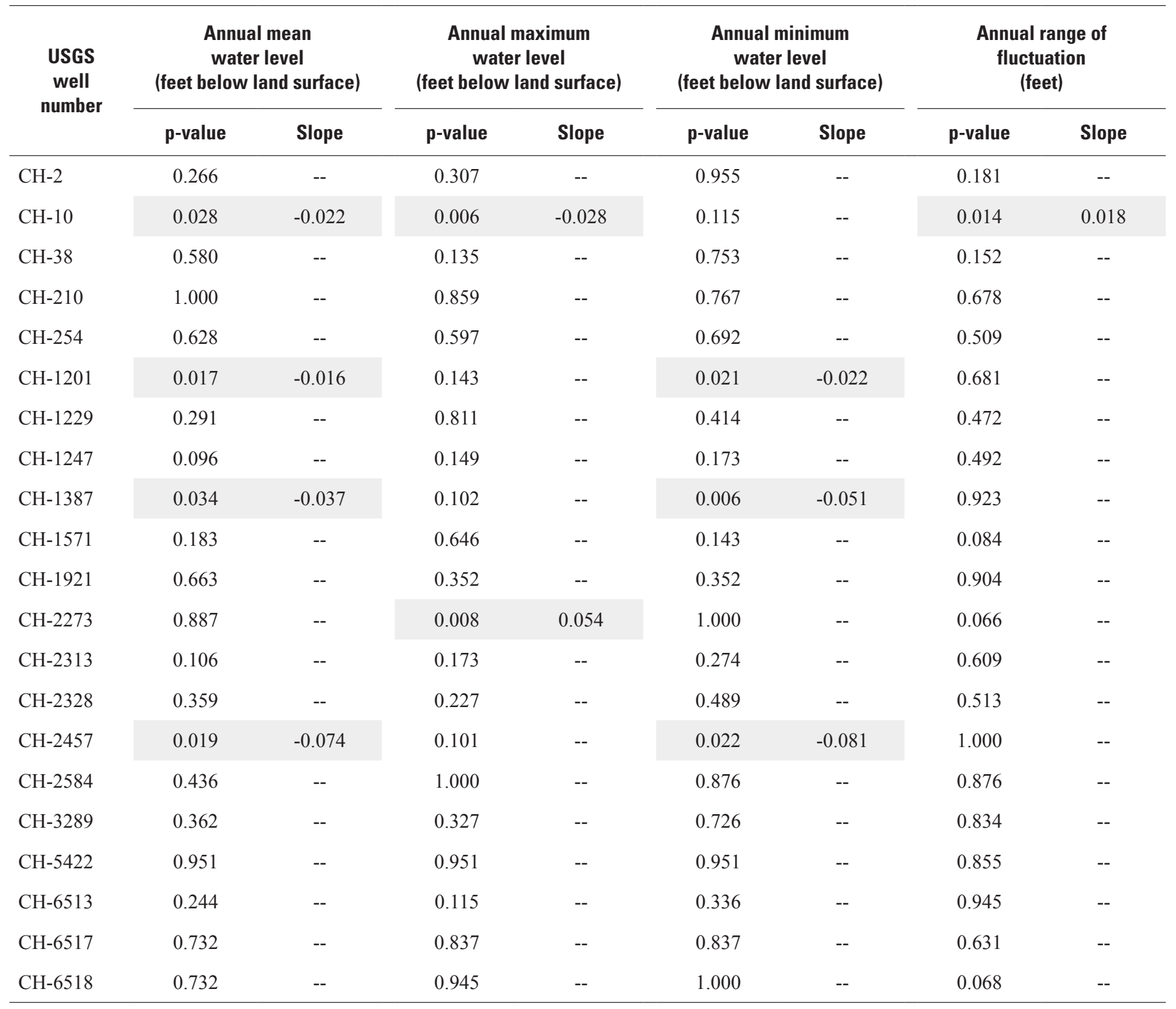

annual precipitation at a nearby NOAA precipitation station (table 10). There was virtually no correlation. Groundwater levels and precipitation likely do not correlate because soil moisture and evapotranspiration are important controlling factors governing how much precipitation reaches the aquifer as recharge.

\section{Precipitation and Air Temperature}

Long-term precipitation and air-temperature data for Chester County are available for the West Chester (1893-2013) and Phoenixville (1915-2013) NOAA weather stations (fig. 3). Long-term precipitation and temperature data were evaluated for statistically significant trends in annual mean data (table 11) and monthly mean data (table 12). There were no statistically significant trends in annual mean precipitation or annual mean air temperature for either station. Both weather stations showed a decrease in the number of days per year with precipitation equal to or greater than 0.1 inch (table 11, fig. 17). There was no statistically significant trend in the number of days per year with precipitation equal to or greater than 0.5 or 1 inch.

Annual mean minimum air temperature from the NOAA Southeastern Piedmont Climate Division increased 0.2 degrees Fahrenheit (F) per decade between 1896 and 2014 (fig. 18). 


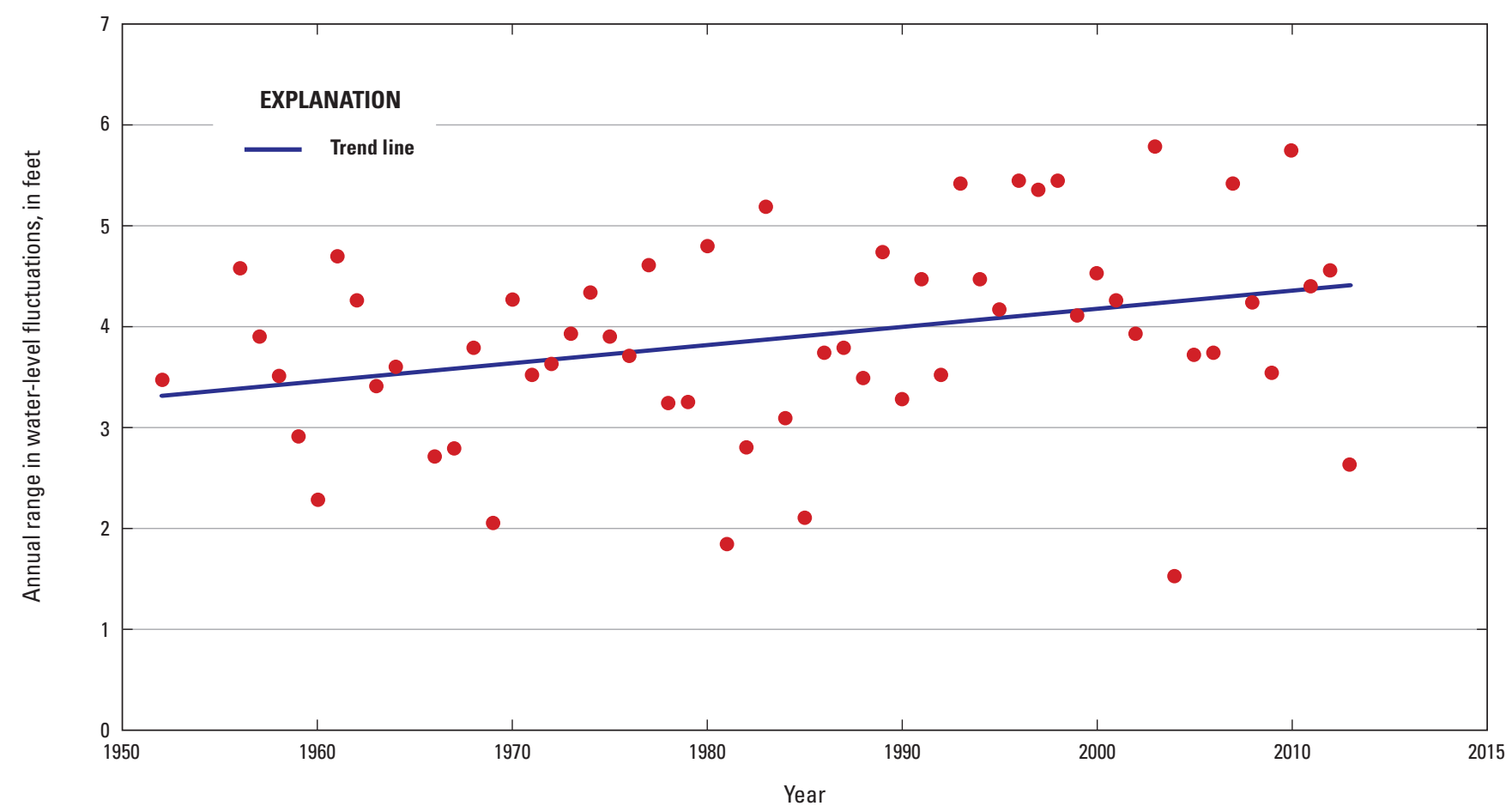

Figure 13. Annual range in water-level fluctuation in well CH-10, Chester County, Pennsylvania, 1952-2013.

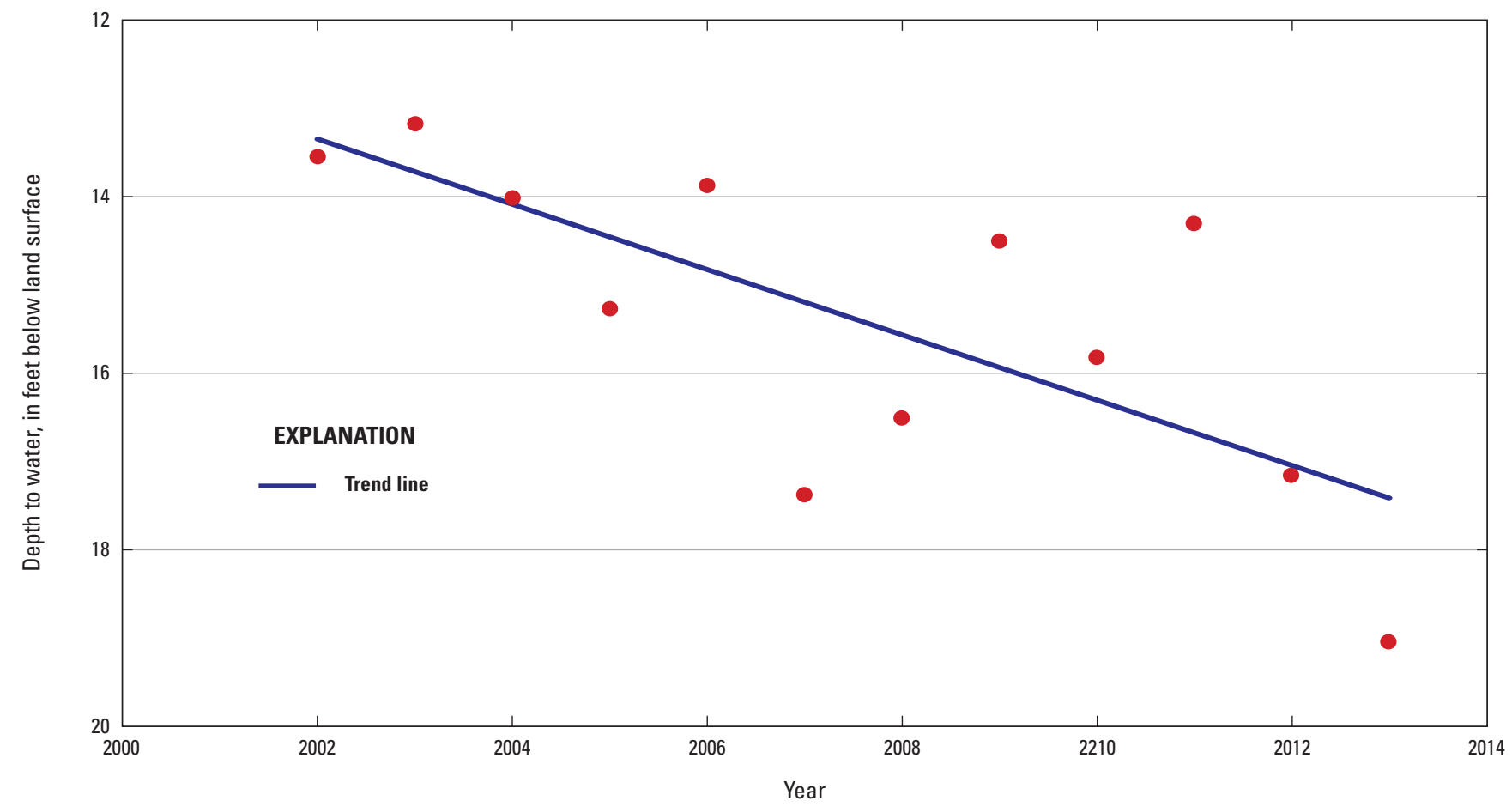

Figure 14. November mean water level in well CH-6513, Chester County, Pennsylvania, 2002-13. 


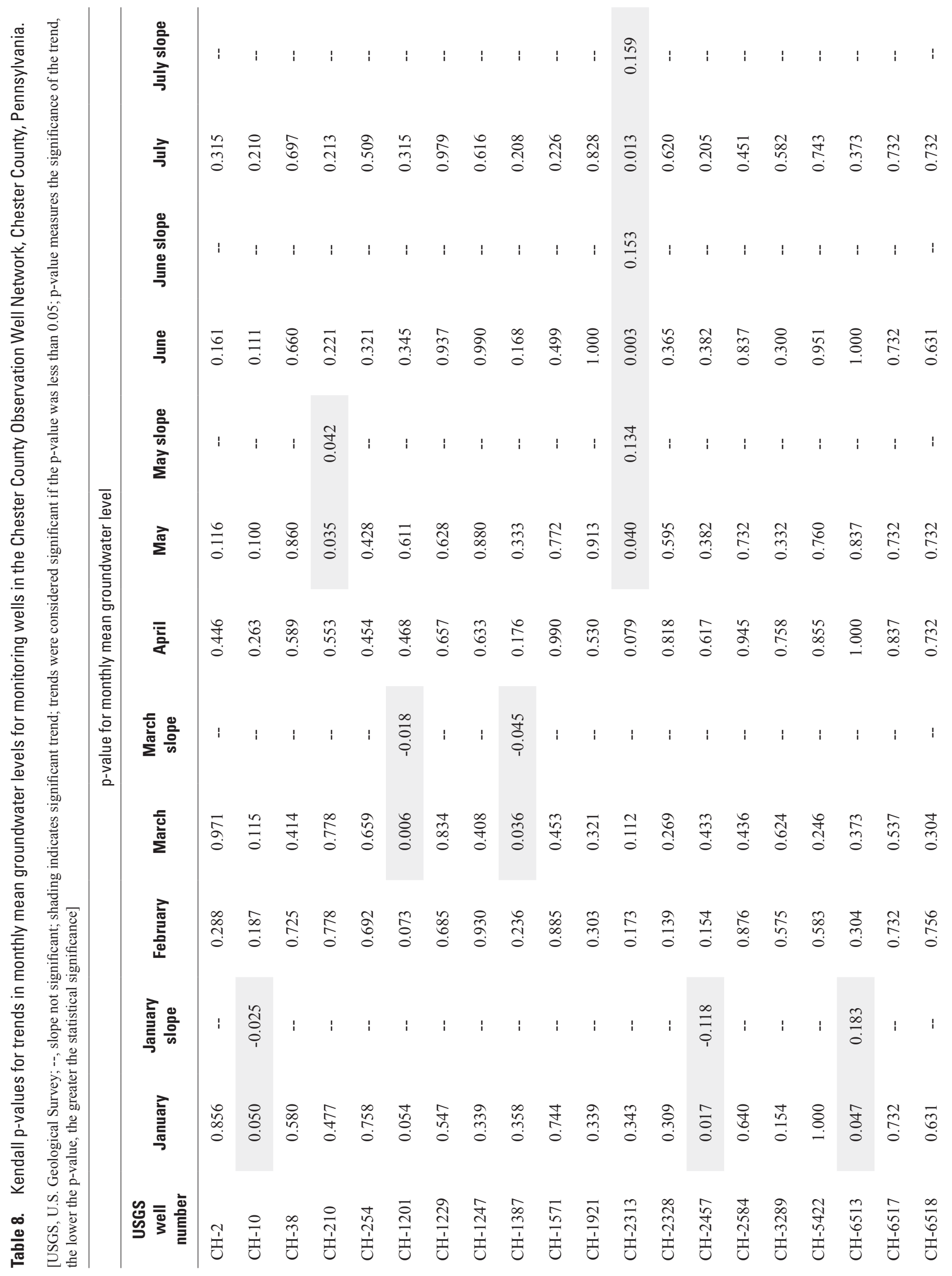




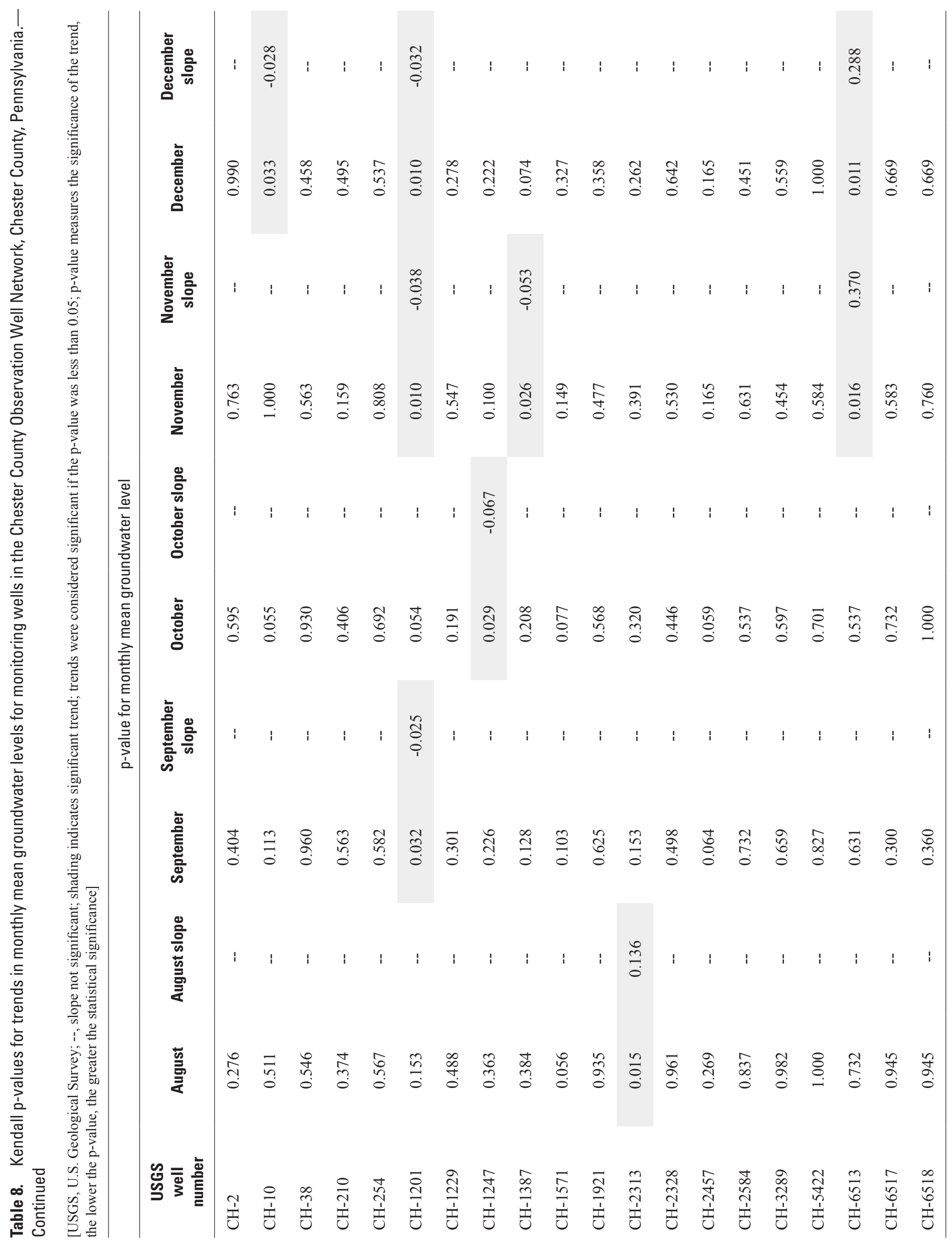


Table 9. Correlation of annual mean groundwater levels for monitoring wells in the Chester County Observation Well Network with annual mean streamflow and base flow at a nearby U.S. Geological Survey streamgage.

[USGS, U.S. Geological Survey; Pa., Pennsylvania; Md., Maryland; Numbers are the correlation coefficient, $\mathrm{r}^{2}$ ]

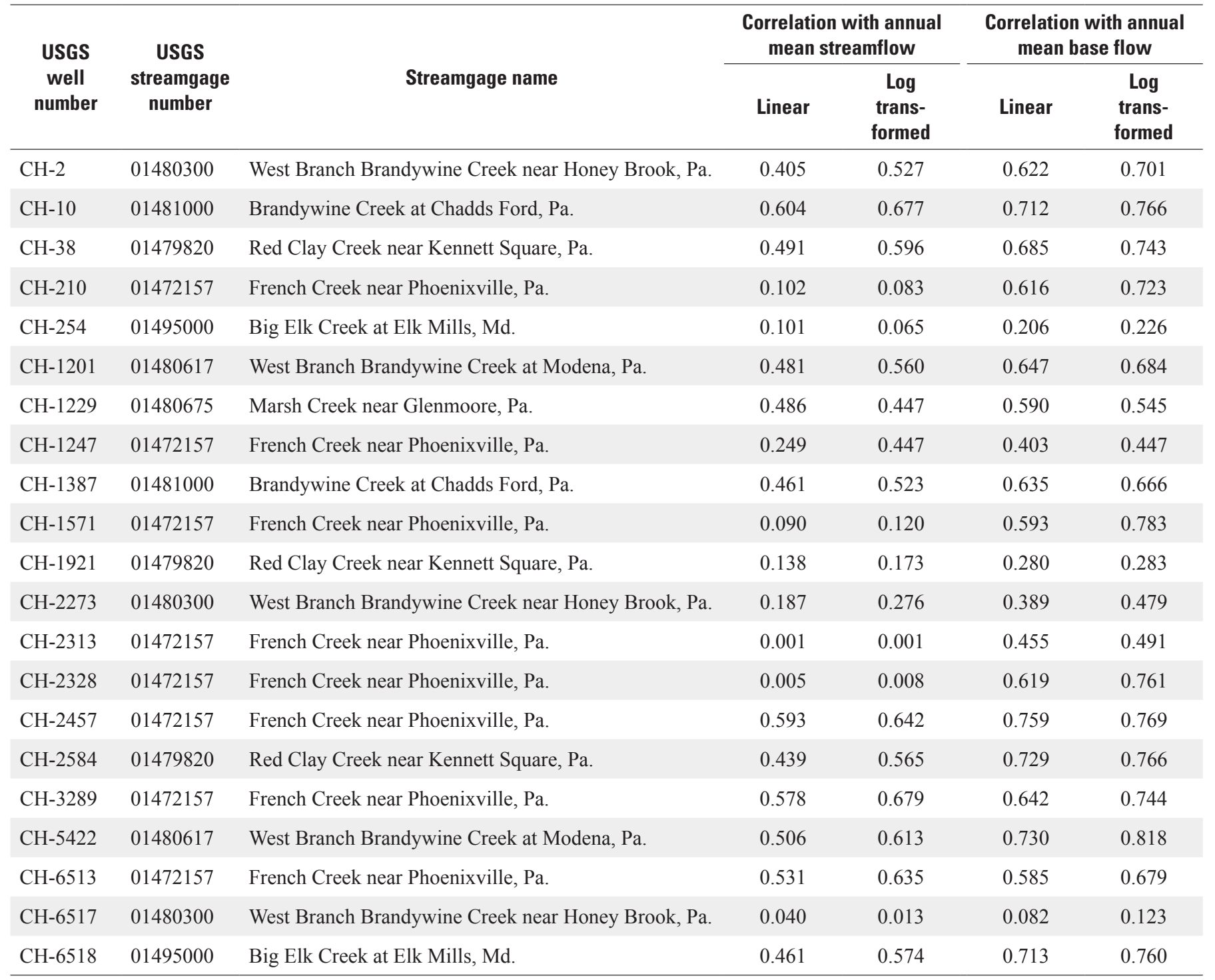

Annual mean maximum temperature from the NOAA Southeastern Piedmont Climate Division increased 0.2 degrees F per decade between 1896 and 2014 (fig. 19). There was no statistically significant trend in the number of days per year with minimum temperature greater than or equal to 0 degrees $\mathrm{F}$ at either station (table 11).

The number of days per year with a maximum air temperature equal to or greater than 90 degrees $\mathrm{F}$ increased at West Chester (fig. 20) and decreased at Phoenixville (table 11). At West Chester the number of days per year with a maximum temperature equal to or greater than 90 degrees $\mathrm{F}$ increased 1.3 days per decade, whereas at Phoenixville, the number of days per year with a maximum air temperature equal to greater than 90 degrees $\mathrm{F}$ decreased 1.1 days per decade.

Long-term monthly precipitation and temperature data were evaluated for statistically significant trends for the
Phoenixville and West Chester weather stations (table 12). Monthly precipitation decreased at West Chester for February. Mean monthly temperature decreased at Phoenixville for June and October (table 12).

Long-term winter snowfall data were not available for a single NOAA station in Chester County. The period of record varied by station and data generally were intermittent during the period of record. Therefore average winter snowfall for each year was estimated using the data available from all NOAA weather stations. Because different weather stations were used for different years, the annual snowfall is considered an estimate of the magnitude of snowfall. Estimated average annual winter snowfall ranged from 2.9 inches (in.) during the winter of 1971-72 to 81.8 in. during the winter of 1995-96 (fig. 21). A trend analysis gave a p-value of 0.066 , indicating no statistically significant trend in annual snowfall amounts. 


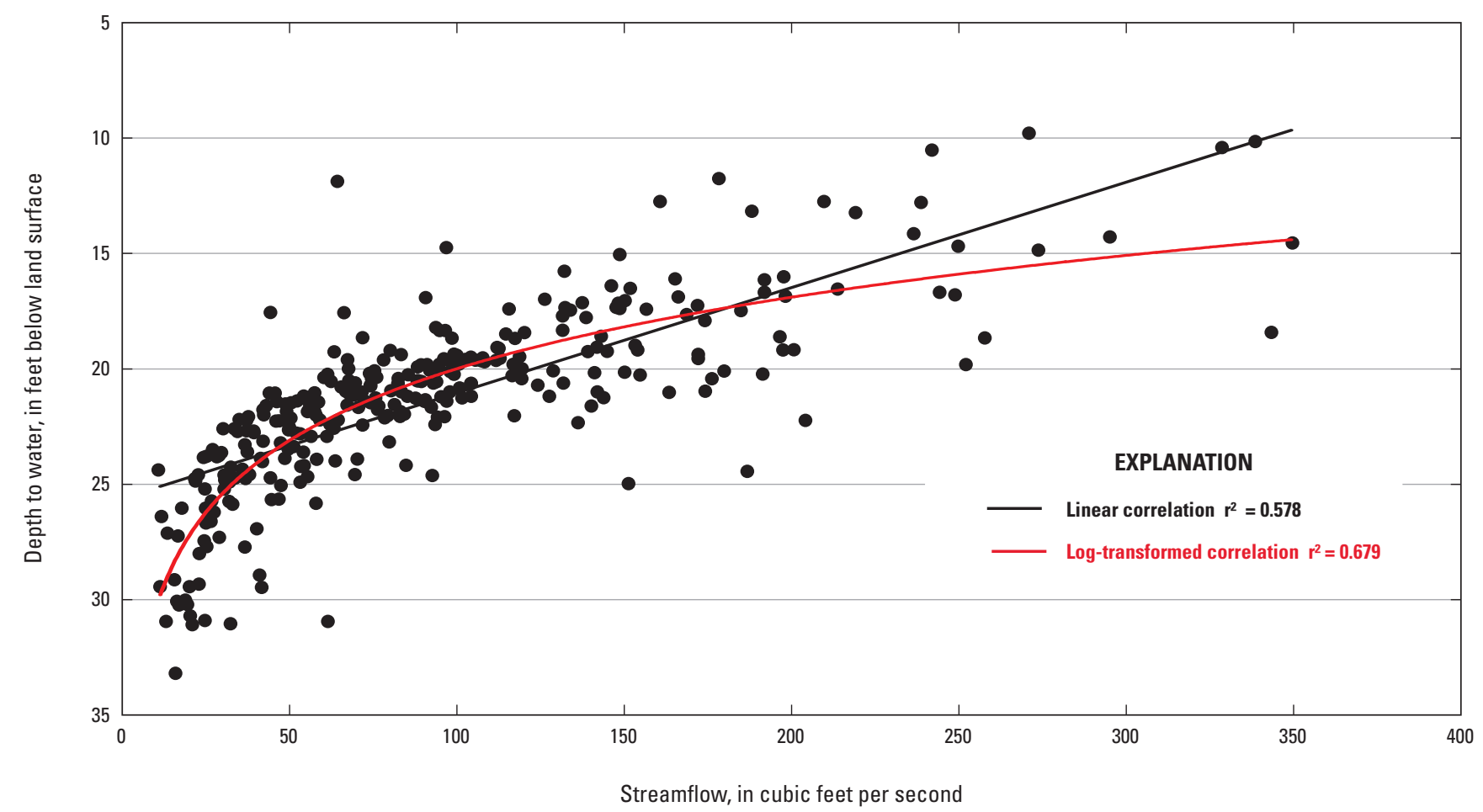

Figure 15. Relation between annual mean water level in well CH-3289, Chester County, Pennsylvania, and annual mean streamflow at streamgage 01472157, French Creek near Phoenixville, Pennsylvania, 1969-2013.

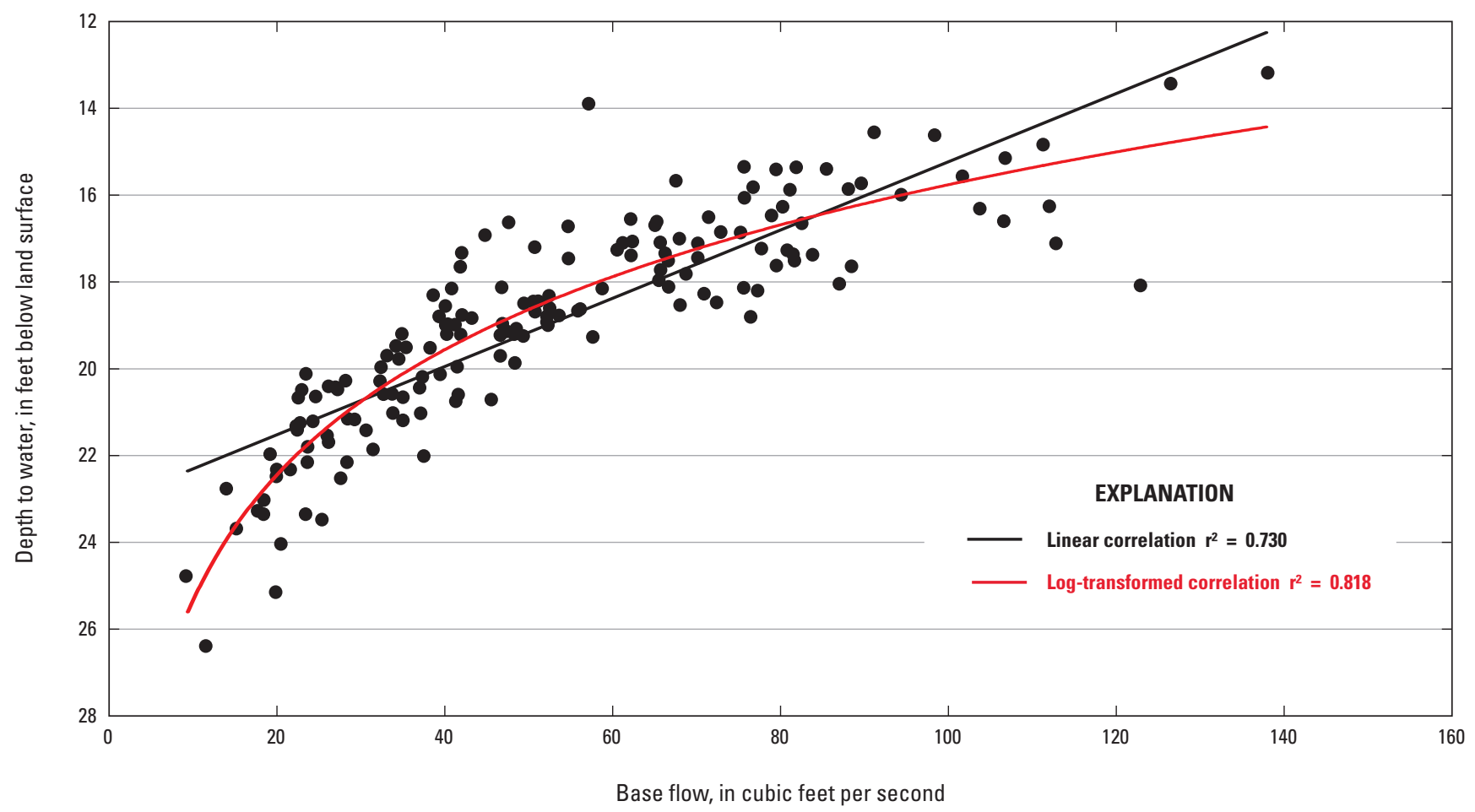

Figure 16. Relation between annual mean water level in well CH-5422, Chester County, Pennsylvania, and annual mean base flow at streamgage 01480617, West Branch Brandywine Creek at Modena, Pennsylvania, 2000-13. 
Table 10. Correlation between annual mean groundwater level and annual precipitation in Chester County Pennsylvania.

[USGS, U.S. Geological Survey; NOAA, National Oceanic and Atmospheric Administration; Pa., Pennsylvania; Numbers are the correlation coefficient, $\mathbf{r}^{2}$ ]

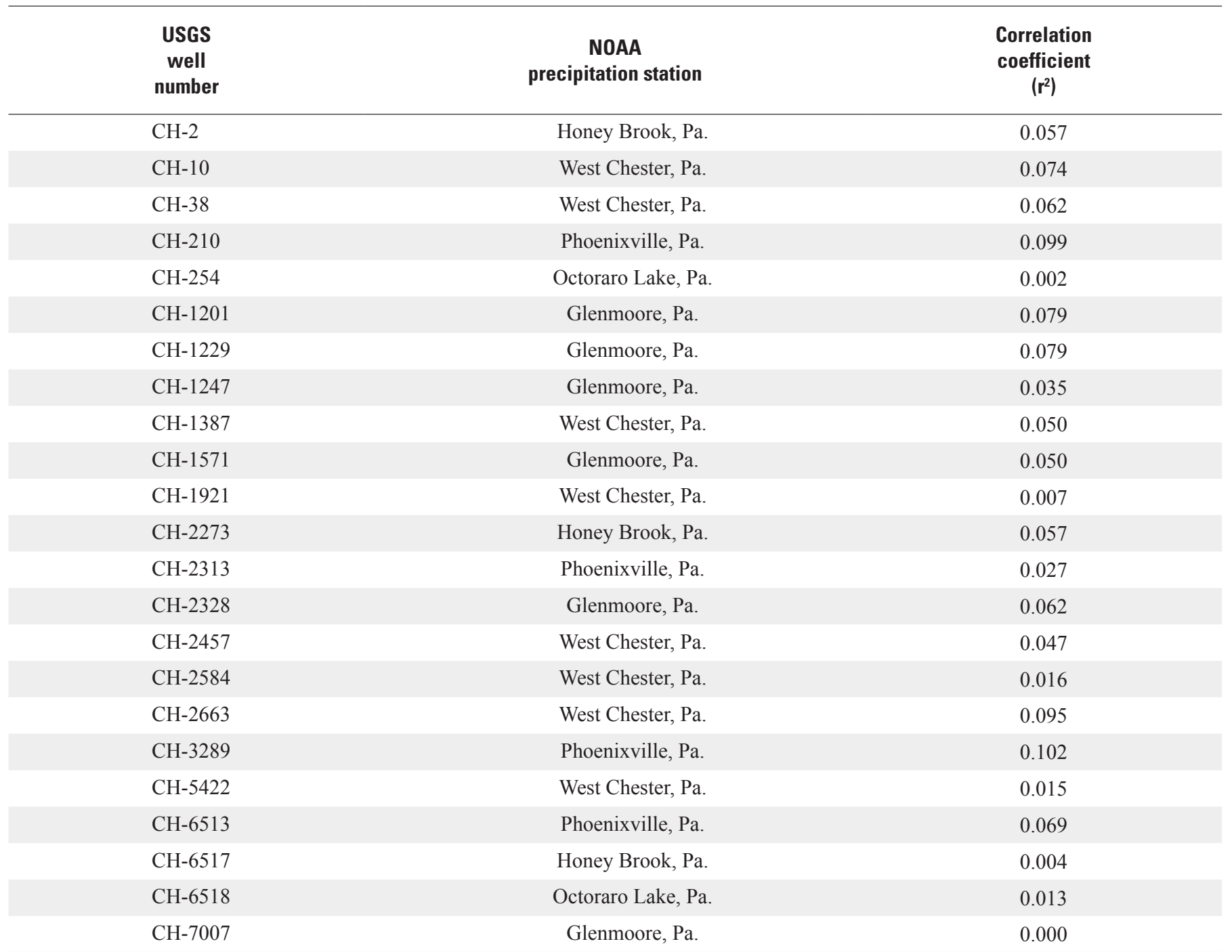

Table 11. Kendall p-values for trends in annual mean precipitation and annual mean air temperature at Phoenixvile and West Chester, Pennsylvania weather stations.

[NOAA, National Oceanic and Atmospheric Administration; shading indicates significant trend; trends were considered significant if the p-value was less than 0.05; p-value measures the significance of the trend, the lower the p-value, the greater the statistical significance; F, Fahrenheit; Pa., Pennsylvania]

\begin{tabular}{|c|c|c|c|c|c|c|c|c|c|}
\hline $\begin{array}{l}\text { NOAA } \\
\text { station }\end{array}$ & $\begin{array}{c}\text { p-value } \\
\text { for annual } \\
\text { mean pre- } \\
\text { cipitation }\end{array}$ & $\begin{array}{c}\text { p-value } \\
\text { for annual } \\
\text { mean tem- } \\
\text { perature }\end{array}$ & \multicolumn{2}{|c|}{$\begin{array}{l}\text { Number of days } \\
\text { with precipitation } \\
\text { equal to or greater } \\
\text { than } 0.1 \text { inch }\end{array}$} & $\begin{array}{c}\begin{array}{c}\text { Number of } \\
\text { days with } \\
\text { precipitation } \\
\text { equal to or }\end{array} \\
\text { greater than } \\
0.5 \text { inch } \\
\text { p-value }\end{array}$ & $\begin{array}{c}\begin{array}{c}\text { Number of } \\
\text { days with } \\
\text { precipitation } \\
\text { equal to or } \\
\text { greater than } \\
1 \text { inch }\end{array} \\
\text { p-value }\end{array}$ & $\begin{array}{c}\text { Number of } \\
\text { days with } \\
\text { minimum } \\
\text { temperature } \\
\text { equal to or } \\
\text { greater than } \\
\text { O degrees } F \\
\text { p-value }\end{array}$ & \multicolumn{2}{|c|}{$\begin{array}{l}\text { Number of days } \\
\text { with maximum } \\
\text { temperature equa } \\
\text { to or greater than } \\
90 \text { degrees } F\end{array}$} \\
\hline Phoenixville, $\mathrm{Pa}$. & 0.995 & 0.333 & 0.031 & -0.074 & 0.621 & 0.361 & 0.158 & 0.044 & -0.111 \\
\hline West Chester, $\mathrm{Pa}$. & 0.845 & 0.789 & 0.009 & -0.070 & 0.943 & 0.353 & 0.176 & 0.0002 & 0.125 \\
\hline
\end{tabular}



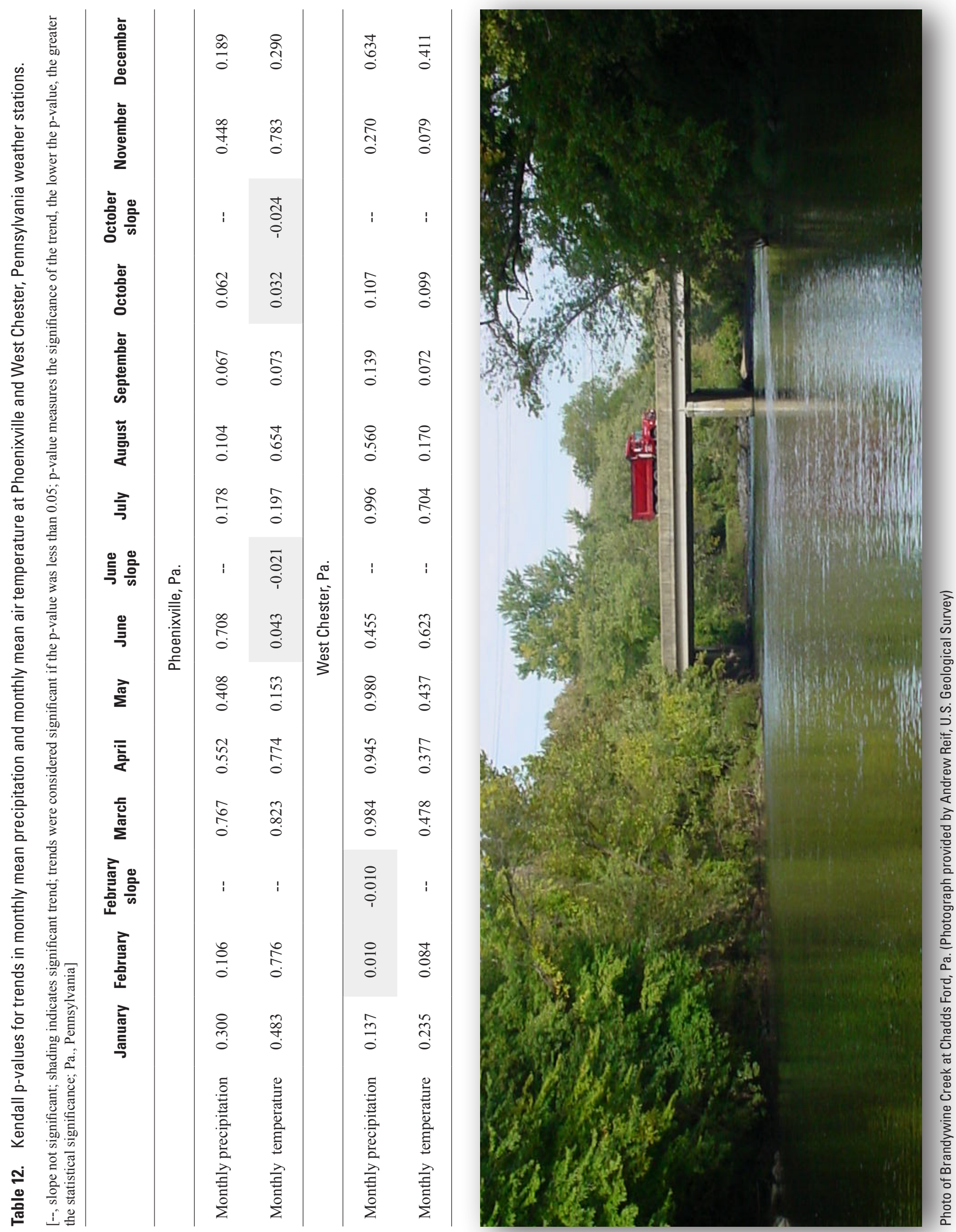


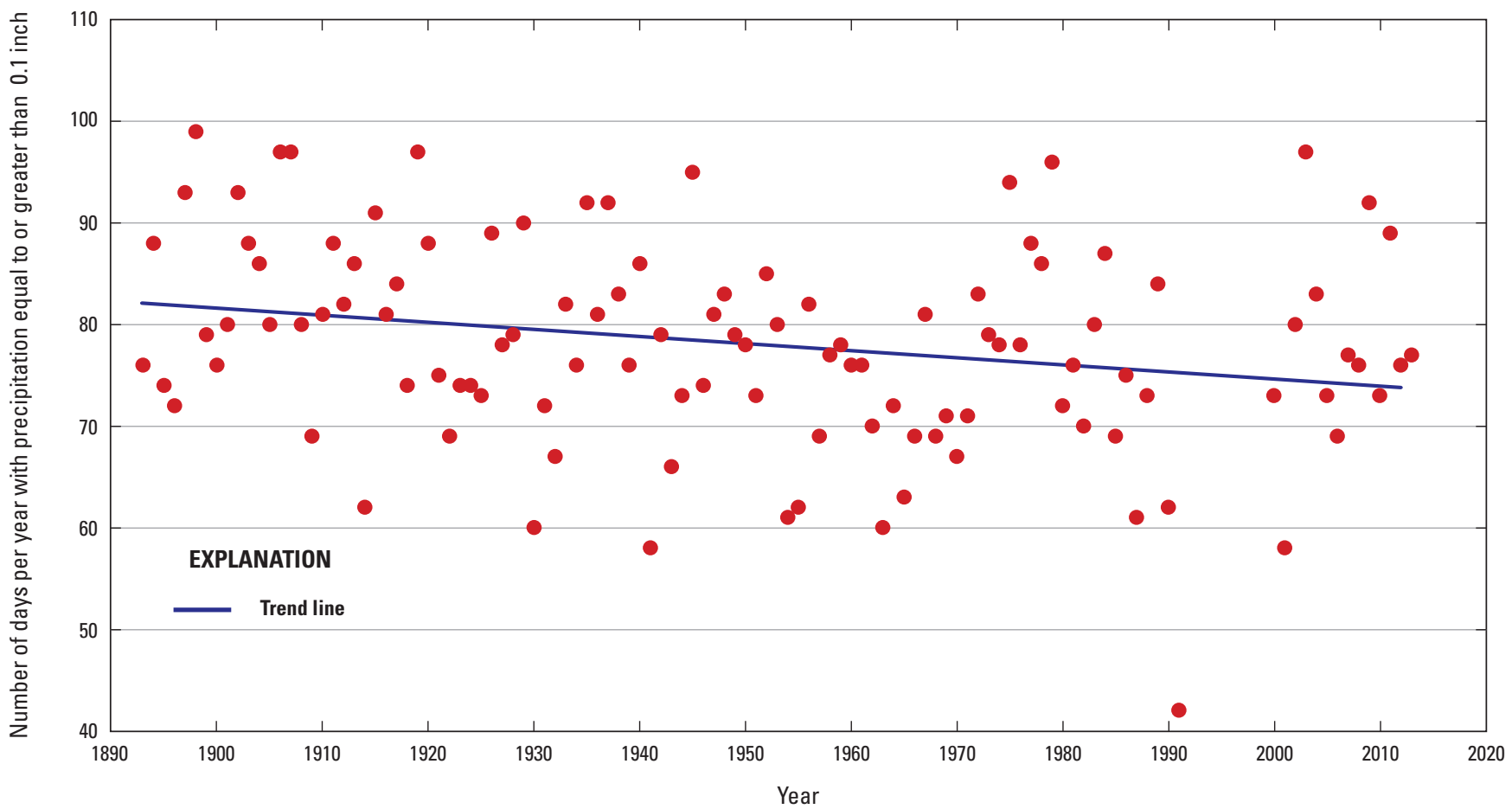

Figure 17. Number of days per year with precipitation equal to or greater than 0.1 inch at West Chester, Pennsylvania weather station, 1893-2013.

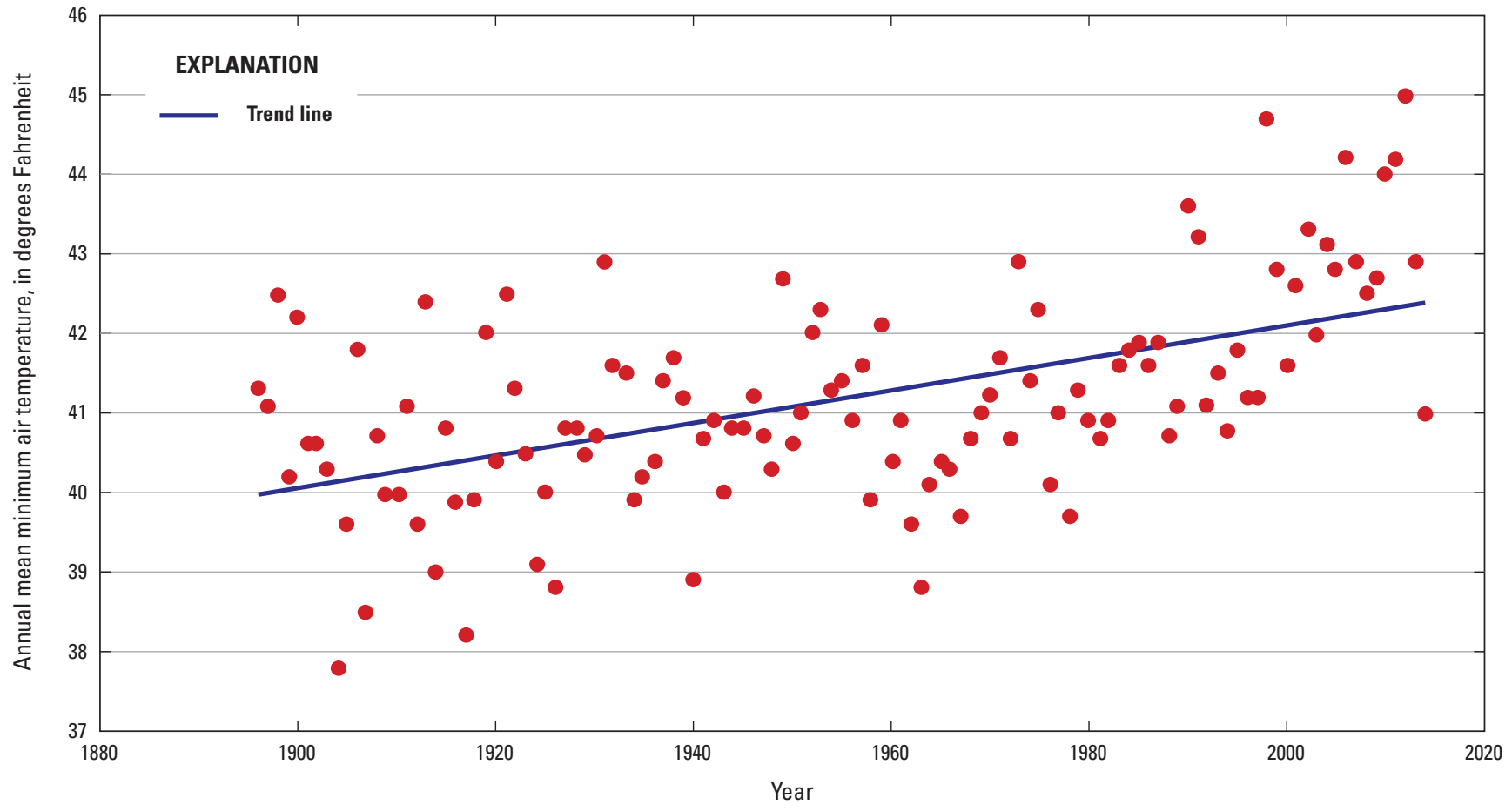

Figure 18. Annual mean minimum temperature in Chester County, Pennsylvania, from the National Oceanic and Atmospheric Administration, Southeastern Pennsylvania Piedmont Climate Division, 1896-2014. 


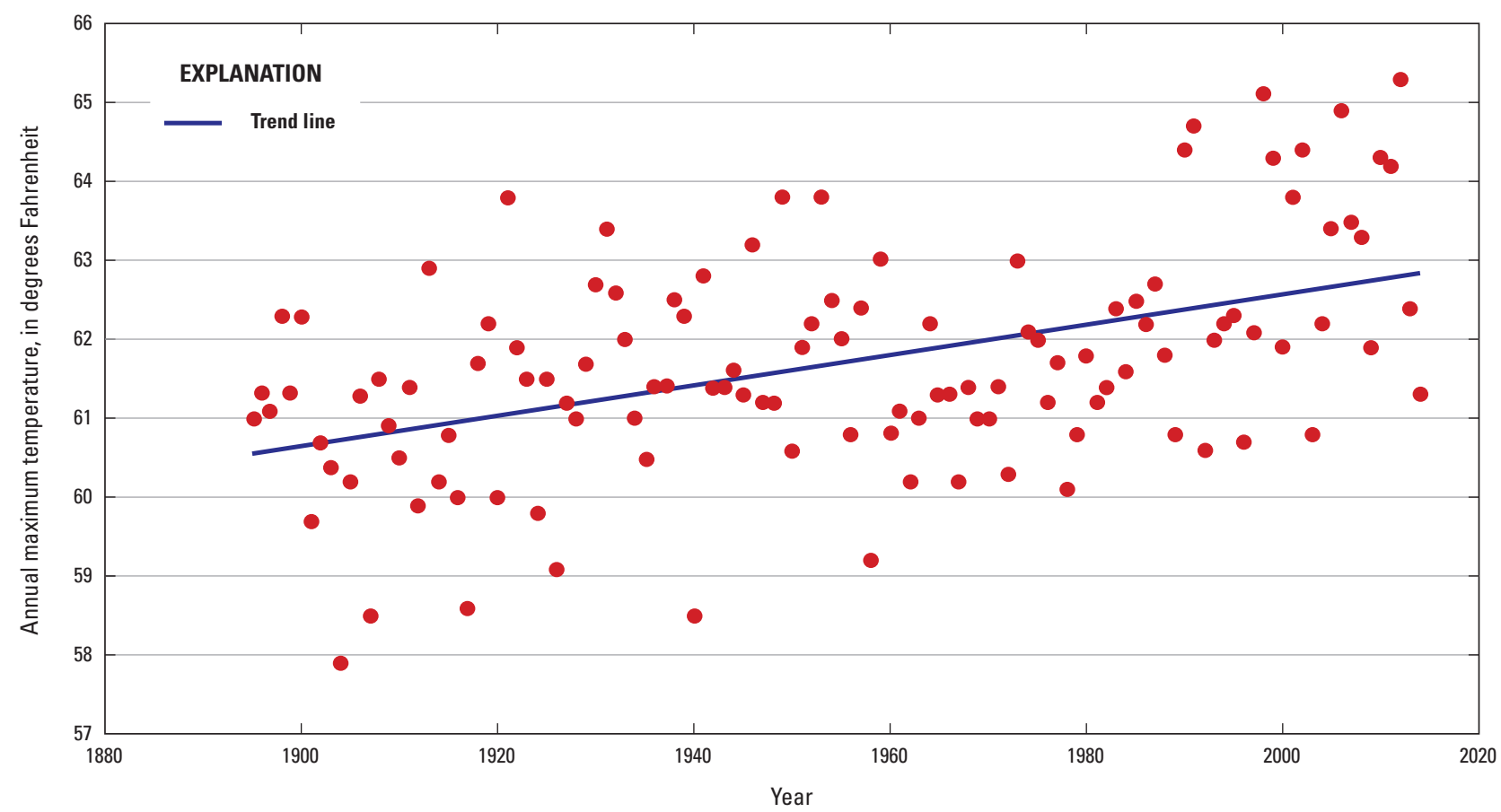

Figure 19. Annual mean maximum air temperature in Chester County, Pennsylvania, from the National Oceanic and Atmospheric Administration, Southeastern Pennsylvania Piedmont Climate Division, 1896-2014.

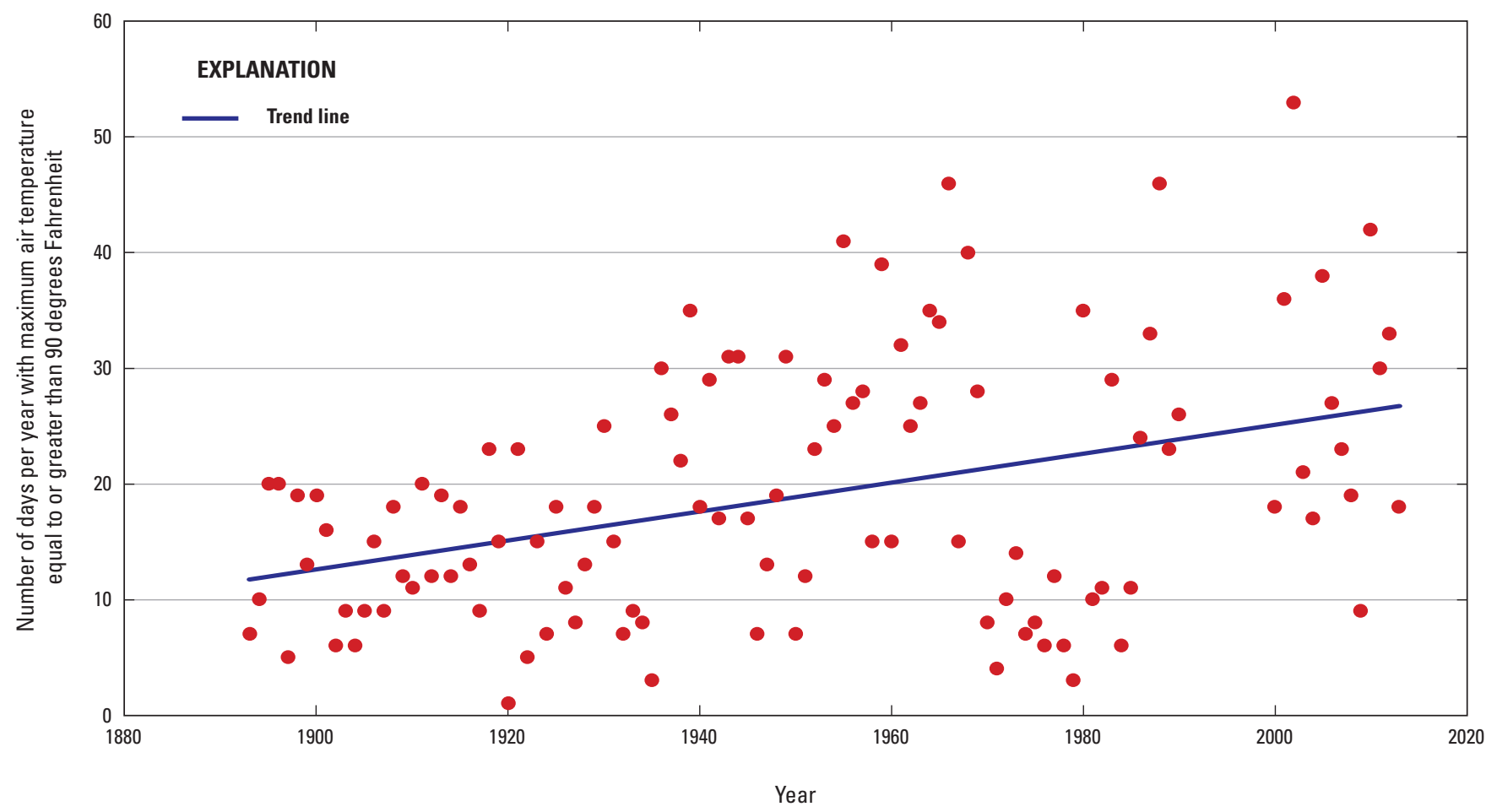

Figure 20. Number of days per year with a maximum air temperature equal to or greater than 90 degrees Fahrenheit at West Chester Pennsylvania weather station, 1893-2013. 


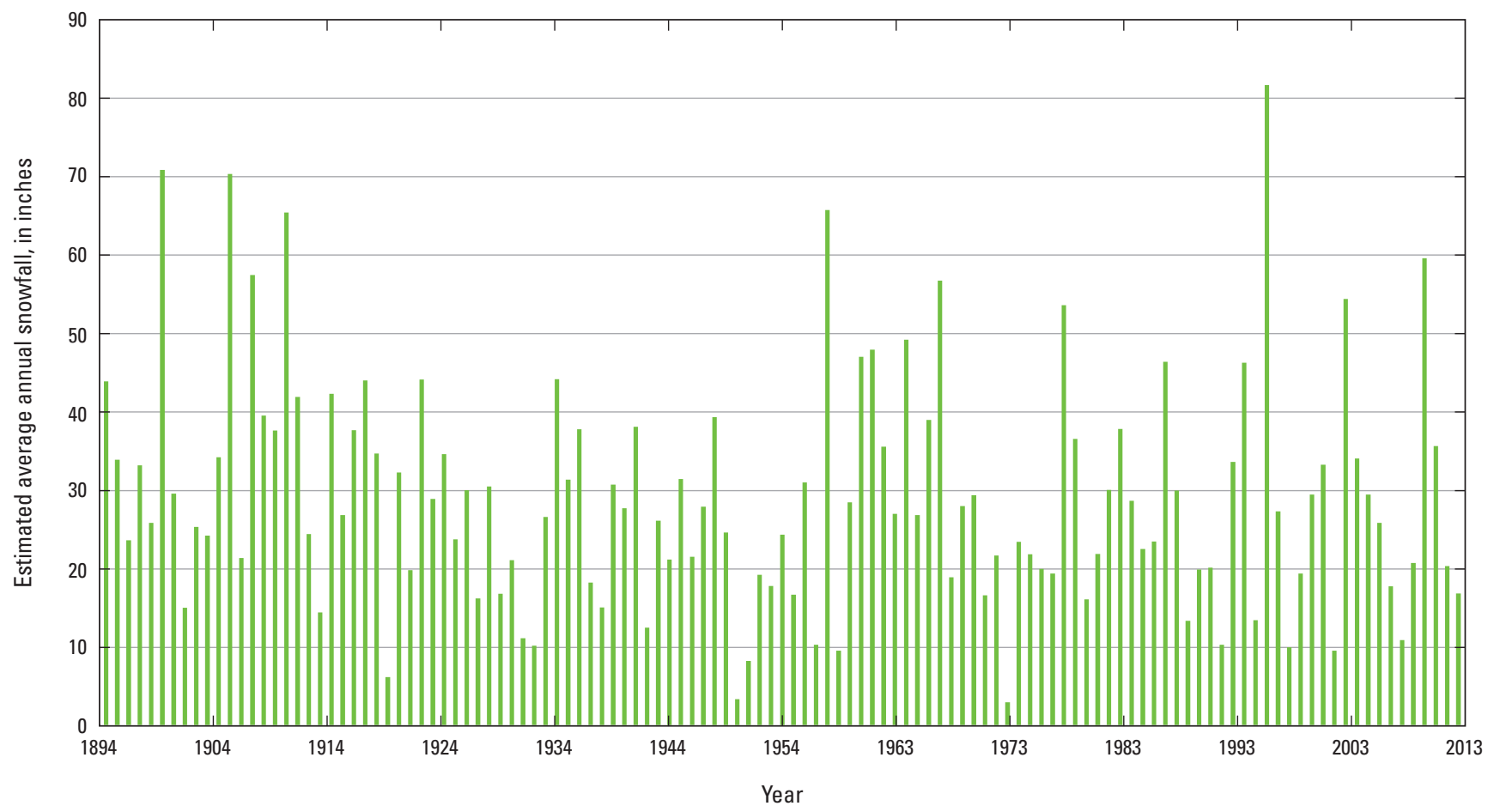

Figure 21. Estimated average annual snowfall in Chester County, Pennsylvania. 1894-2013.

\section{Evaluation of Long-Term Trends in Water-Quality Conditions}

\section{Stream Water Quality}

Stream water-quality monitors have been in operation on the Brandywine Creek in Chester County since 1972. Stream water-quality monitors operate in non-winter months (March 1 through November 30) at Brandywine Creek at Chadds Ford, Pa. (01481000), East Branch Brandywine Creek below Downingtown, Pa. (01480870), and West Branch Brandywine Creek at Modena, Pa. (01480617) streamgages (table 13, fig. 1). Measurements are made at the stream water-quality monitoring stations for $\mathrm{pH}$, specific conductance, temperature, and dissolved oxygen concentration. Data prior to 1974 were not used in this evaluation owing to the influence of releases from Marsh Creek Reservoir, which was completed in 1974.

The only previous evaluation of data collected at the stream water-quality monitoring stations was for data collected from 1973 to 1978 by Murphy and others (1982). They found that the East Branch Brandywine Creek below Downingtown, $\mathrm{Pa}$. (01480870) and the West Branch Brandywine Creek at Modena, Pa. (01480617) stream water-quality monitors recorded periods when the dissolved oxygen concentration dropped to less than 4 milligrams per liter $(\mathrm{mg} / \mathrm{L})$. There was a severe dissolved oxygen deficiency at East Branch
Brandywine Creek below Downingtown, Pa. (01480870) from May through September 1974 when concentrations were less than $4 \mathrm{mg} / \mathrm{L}$ for at least a portion of 96 days (table 15). The $\mathrm{pH}$ at all three Brandywine Creek stream water-quality monitoring stations exceeded 9.0 at times, and the $\mathrm{pH}$ at East Branch Brandywine Creek below Downingtown, Pa. (01480870) occasionally dropped to less than 6.0 (table 15).

The number of days per year since 1974 when the maximum daily $\mathrm{pH}$ was greater than 9.0 and minimum daily $\mathrm{pH}$ was less than 6.0 was evaluated. $\mathrm{pH}$ values outside this range are potentially harmful to aquatic life (U.S. Environmental Protection Agency, 2009). Since 1974, there have been 744 days when the $\mathrm{pH}$ was outside this range (table 14-16). Minimum daily $\mathrm{pH}$ values from measurements are rarely less than 6.0. Maximum daily $\mathrm{pH}$ values greater than 9.0 were rarely measured at East Branch Brandywine Creek below Downingtown, Pa. (01480870) or Brandywine Creek at Chadds Ford, Pa. (01481000) but were regularly measured at West Branch Brandywine Creek at Modena, Pa. (01480617).

The number of days per year since 1974 when the minimum daily dissolved oxygen concentration was less than $6 \mathrm{mg} / \mathrm{L}$ was evaluated. Low dissolved oxygen concentrations have a detrimental effect on aquatic life. Prior to 1988, it was common in the summer months for minimum daily dissolved oxygen concentrations at East Branch Brandywine Creek below Downingtown, Pa. (01480870) and West Branch Brandywine Creek at Modena, Pa. (01480617) to be less than $6 \mathrm{mg} / \mathrm{L}$. Since 1988, the number of days the minimum dissolved oxygen concentration was less than $6 \mathrm{mg} / \mathrm{L}$ has 
Table 13. Stream water-quality monitors in Chester County, Pennsylvania.

[USGS, U.S. Geological Survey; CY, current year; T, temperature; SC, specific conductance; DO, dissolved oxygen concentration; Pa., Pennsylvania]

\begin{tabular}{llcl}
\hline $\begin{array}{c}\text { USGS } \\
\text { station } \\
\text { number }\end{array}$ & Station name & Period of record & Characteristic \\
\hline 01480617 & West Branch Brandywine Creek at Modena, Pa. & $1971-\mathrm{CY}$ & $\mathrm{T}, \mathrm{SC}, \mathrm{DO}, \mathrm{pH}$ \\
01480870 & East Branch Brandywine Creek below Downingtown, Pa. & $1972-\mathrm{CY}$ & $\mathrm{T}, \mathrm{SC}, \mathrm{DO}, \mathrm{pH}$ \\
01481000 & Brandywine Creek at Chadds Ford, Pa. & $1972-\mathrm{CY}$ & $\mathrm{T}, \mathrm{SC}, \mathrm{DO}, \mathrm{pH}$ \\
\hline
\end{tabular}

decreased at East Branch Brandywine Creek below Downingtown, Pa. (01480870) and West Branch Brandywine Creek at Modena, Pa. (01480617). In 2002, there were numerous days that the minimum dissolved oxygen concentration was less than $6 \mathrm{mg} / \mathrm{L}$ at all three stream water-quality monitoring stations, which was related to very low flow conditions in the summer of 2002. Since 2002, the minimum daily dissolved oxygen concentration was less than $6 \mathrm{mg} / \mathrm{L}$ for 28 days at West Branch Brandywine Creek at Modena, Pa. (01480617) and 16 days at East Branch Brandywine Creek below Downingtown, Pa. (01480870) and Brandywine Creek at Chadds Ford, Pa. (01481000) (table 14-16). The records show a substantial improvement in the $\mathrm{pH}$ and dissolved oxygen concentration in the Brandywine Creek over time.

For this study, specific conductance, $\mathrm{pH}$, stream temperature, and dissolved oxygen concentration data were evaluated for statistically significant trends. Specific conductance values were not adjusted for streamflow, and dissolved oxygen concentrations were not adjusted for temperature. Because regulation began affecting all three of these stations in 1974, only data from 1974 to 2013 were evaluated; this provides a concurrent period of record for the analysis.

Statistically significant trends were evaluated for 1974-2013 for annual mean specific conductance, $\mathrm{pH}$, stream temperature, and dissolved oxygen concentration (table 17). The minimum number of daily values for each month for the analysis was 15 . Months with less than 15 daily values were not included in the analysis.

Statistically significant upward trends were observed for annual mean specific conductance at all three Brandywine Creek water quality monitoring stations (fig. 22). The increase in specific conductance was 22 microsiemens per centimeter at 25 degrees Celsius $\left(\mu \mathrm{S} / \mathrm{cm}\right.$ at $\left.25^{\circ} \mathrm{C}\right)$ per decade at West Branch Brandywine Creek at Modena, Pa. (01480617), and $23 \mu \mathrm{S} / \mathrm{cm}$ at $25^{\circ} \mathrm{C}$ per decade at East Branch Brandywine Creek below Downingtown, Pa. (01480870) and Brandywine Creek at Chadds Ford, Pa. (01481000). If the trend continues, the mean annual specific conductance could be as high as $395 \mu \mathrm{S} / \mathrm{cm}$ at $25^{\circ} \mathrm{C}$ at Brandywine Creek at Chadds Ford, Pa. (01481000), $404 \mu \mathrm{S} / \mathrm{cm}$ at $25^{\circ} \mathrm{C}$ at East Branch Brandywine
Creek below Downingtown, Pa. (01480870), and $444 \mu \mathrm{S} / \mathrm{cm}$ at $25^{\circ} \mathrm{C}$ at West Branch Brandywine Creek at Modena, Pa. (01480617) by 2050 (fig. 23). Specific conductance increases with increasing amount of dissolved solids (Kappel and others, 2012). Therefore, the increasing specific conductance can be viewed as increasing total dissolved solids load over time at the three stream water-quality monitoring stations.

The increase in specific conductance likely is due to increases in chloride. Statistically significant upward trends in chloride have been documented at various stream locations in Chester County between 1998 and 2009 (Reif, 2012). An upward trend in chloride concentrations was determined for Brandywine Creek at Chadds Ford, Pa. (01481000) for 1948-2013 (fig. 24). The period of record for chloride data is shorter at the West Branch Brandywine Creek at Modena, Pa. (01480617) and East Branch Brandywine Creek below Downingtown, Pa. (01480870), but both show an increase in chloride concentration over time. The source of increasing chloride may be road salt, effluent discharged to the stream, and (or) effluent in groundwater discharged to streams as base flow.

Statistically significant upward trends in $\mathrm{pH}$ were observed at all three stream water-quality stations (table 17, fig. 25). The increase in $\mathrm{pH}$ is $0.08 \mathrm{pH}$ unit per decade at West Branch Brandywine Creek at Modena, Pa. (01480617), $0.1 \mathrm{pH}$ unit per decade at East Branch Brandywine Creek below Downingtown, Pa. (01480870), and $0.04 \mathrm{pH}$ unit per decade at Brandywine Creek at Chadds Ford, Pa. (01481000). Statistically significant upward trends in stream temperature were observed at the East Branch Brandywine Creek below Downingtown, Pa. (01480870) and Brandywine Creek at Chadds Ford, Pa. (01481000) stations (table 17). The increase in stream temperature was 0.5 degree Celsius (C; 0.9 degree $\mathrm{F}$ ) per decade at East Branch Brandywine Creek below Downingtown, Pa. (01480870) and 0.6 degree $\mathrm{C}$ (1 degree F) per decade at Brandywine Creek at Chadds Ford, Pa. (01481000). The warming may be caused by climatic changes, warming of the earth's surface caused by urbanization, and (or) increasing quantities of warm effluent discharged to Brandywine Creek. There was a statistically significant increase in dissolved oxygen concentration at West Branch Brandywine Creek at 
Table 14. Number of days per year stream water quality exceeded standards at water-quality monitoring station 01480617, West Branch Brandywine Creek at Modena, Pennsylvania, 1974-2014.

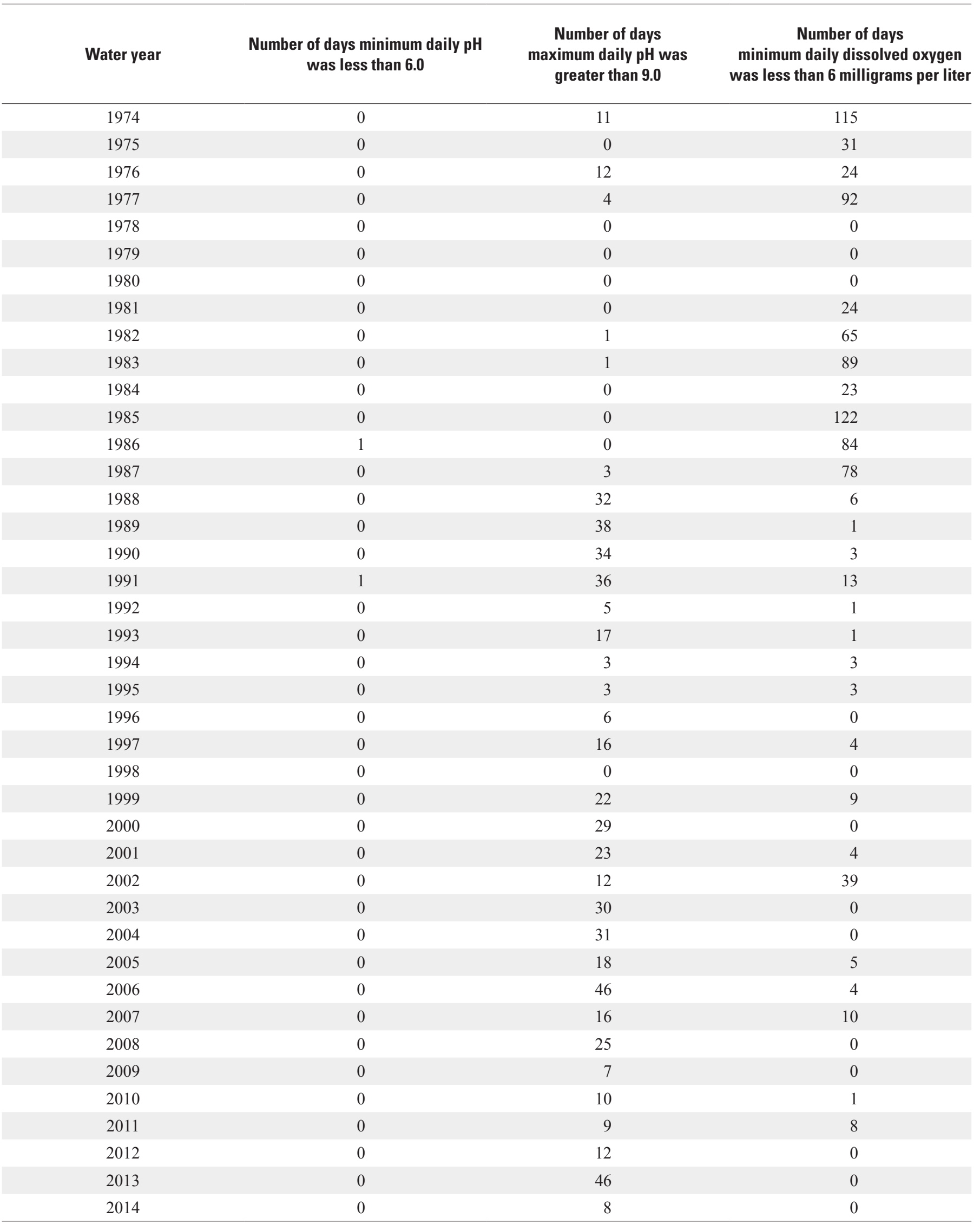


Table 15. Number of days per year stream water quality exceeded standards at water-quality monitoring station 01480870, East Branch Brandywine Creek below Downingtown, Pennsylvania, 1974-2014.

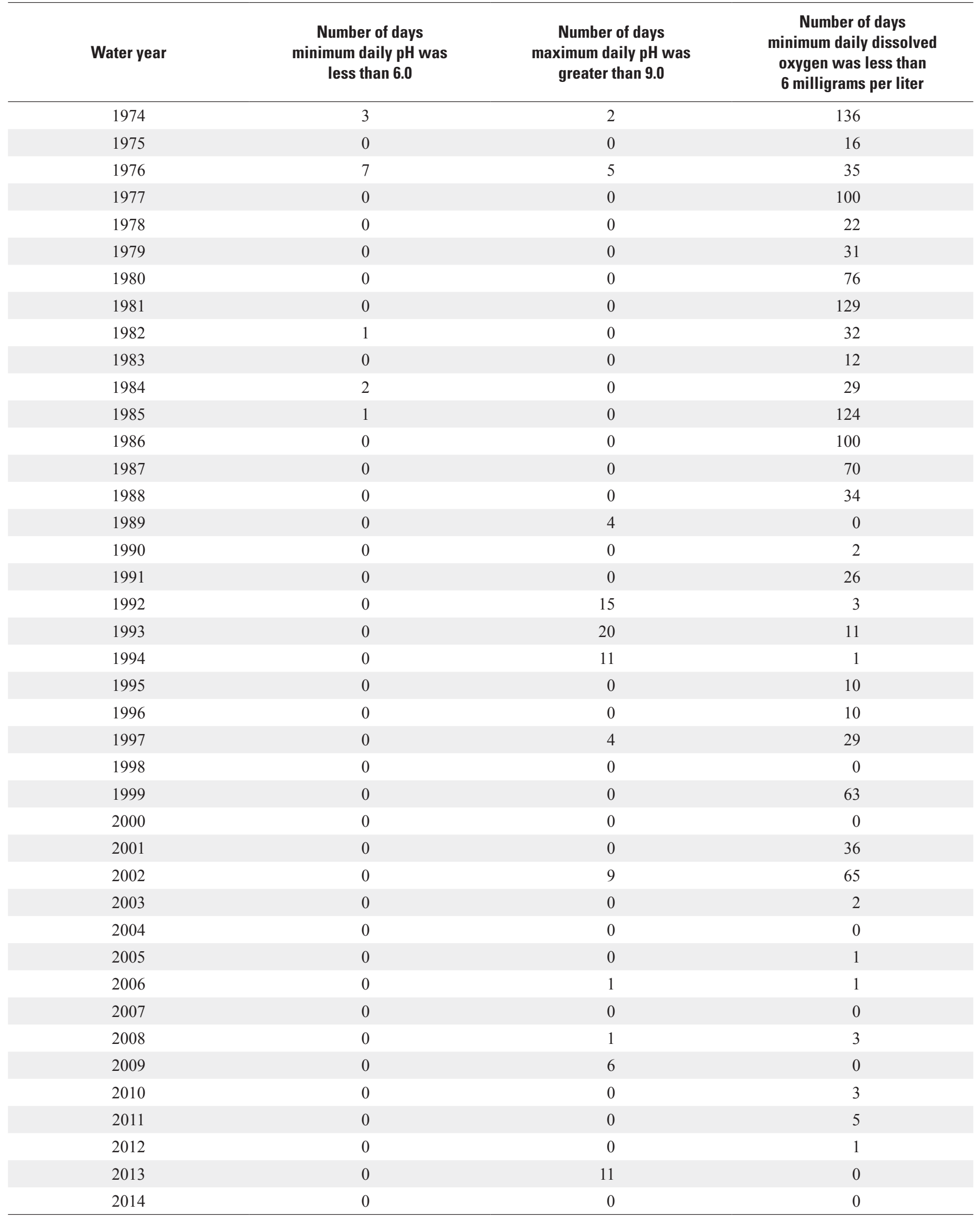


Table 16. Number of days per year stream water quality exceeded standards at water-quality monitoring station 01481000, Brandywine Creek at Chadds Ford, Pennsylvania, 1974-2014.

\begin{tabular}{|c|c|c|c|}
\hline Water year & $\begin{array}{l}\text { Number of days } \\
\text { minimum daily } \mathrm{pH} \\
\text { was less than } 6.0\end{array}$ & $\begin{array}{c}\text { Number of days } \\
\text { maximum daily } \mathrm{pH} \\
\text { was greater than } 9.0\end{array}$ & $\begin{array}{c}\text { Number of days } \\
\text { minimum daily dissolved } \\
\text { oxygen was less than } 6 \\
\text { milligrams per liter }\end{array}$ \\
\hline 1974 & 0 & 2 & 16 \\
\hline 1975 & 0 & 6 & 6 \\
\hline 1976 & 0 & 3 & 11 \\
\hline 1978 & 0 & 0 & 4 \\
\hline 1979 & 0 & 7 & 3 \\
\hline 1980 & 0 & 0 & 18 \\
\hline 1981 & 0 & 3 & 9 \\
\hline 1985 & 0 & 14 & 7 \\
\hline 1986 & 0 & 7 & 0 \\
\hline 1987 & 0 & 1 & 1 \\
\hline 1988 & 0 & 5 & 0 \\
\hline 1989 & 0 & 0 & 1 \\
\hline 1990 & 0 & 0 & 1 \\
\hline 1991 & 0 & 3 & 2 \\
\hline 1992 & 0 & 4 & 1 \\
\hline 1993 & 0 & 0 & 1 \\
\hline 1999 & 0 & 0 & 20 \\
\hline 2000 & 0 & 0 & 1 \\
\hline 2001 & 0 & 0 & 6 \\
\hline 2002 & 0 & 1 & 59 \\
\hline 2003 & 0 & 0 & 0 \\
\hline 2004 & 0 & 0 & 0 \\
\hline 2005 & 0 & 0 & 8 \\
\hline 2006 & 0 & 0 & 6 \\
\hline 2007 & 0 & 0 & 0 \\
\hline 2008 & 0 & 0 & 0 \\
\hline 2009 & 0 & 11 & 0 \\
\hline 2010 & 0 & 0 & 0 \\
\hline 2011 & 0 & 1 & 0 \\
\hline 2012 & 0 & 0 & 0 \\
\hline 2013 & 0 & 5 & 2 \\
\hline 2014 & 0 & 0 & 0 \\
\hline
\end{tabular}


Table 17. Kendall p-values for trends in annual mean specific conductance, $\mathrm{pH}$, stream temperature, and dissolved oxygen concentration at selected water-quality monitoring stations in Chester County, Pennsylvania, 1974-2013.

[USGS, U.S. Geological Survey; --, slope not significant; shading indicates significant trend; trends were considered significant if the p-value was less than 0.05; $\mathrm{p}$-value measures the significance of the trend, the lower the $\mathrm{p}$-value, the greater the statistical significance]

\begin{tabular}{|c|c|c|c|c|c|c|c|c|c|}
\hline \multirow{2}{*}{$\begin{array}{c}\text { USGS } \\
\text { station } \\
\text { number }\end{array}$} & \multirow{2}{*}{ Water-quality station } & \multicolumn{2}{|c|}{$\begin{array}{l}\text { Specific } \\
\text { conductance }\end{array}$} & \multicolumn{2}{|c|}{$\mathrm{pH}$} & \multicolumn{2}{|c|}{$\begin{array}{l}\text { Stream } \\
\text { temperature }\end{array}$} & \multicolumn{2}{|c|}{$\begin{array}{l}\text { Dissolved oxygen } \\
\text { concentration }\end{array}$} \\
\hline & & p-value & Slope & p-value & Slope & p-value & Slope & p-value & Slope \\
\hline 01480617 & $\begin{array}{l}\text { West Branch Brandywine Creek at } \\
\text { Modena, Pa. }\end{array}$ & 0.0 & 2.1886 & 0.0002 & 0.0083 & 0.255 & -- & 0.042 & 0.0246 \\
\hline 01481000 & Brandywine Creek at Chadds Ford, Pa. & 0.0 & 2.2522 & 0.0001 & 0.0047 & 0.010 & 0.0614 & 0.334 & -- \\
\hline
\end{tabular}

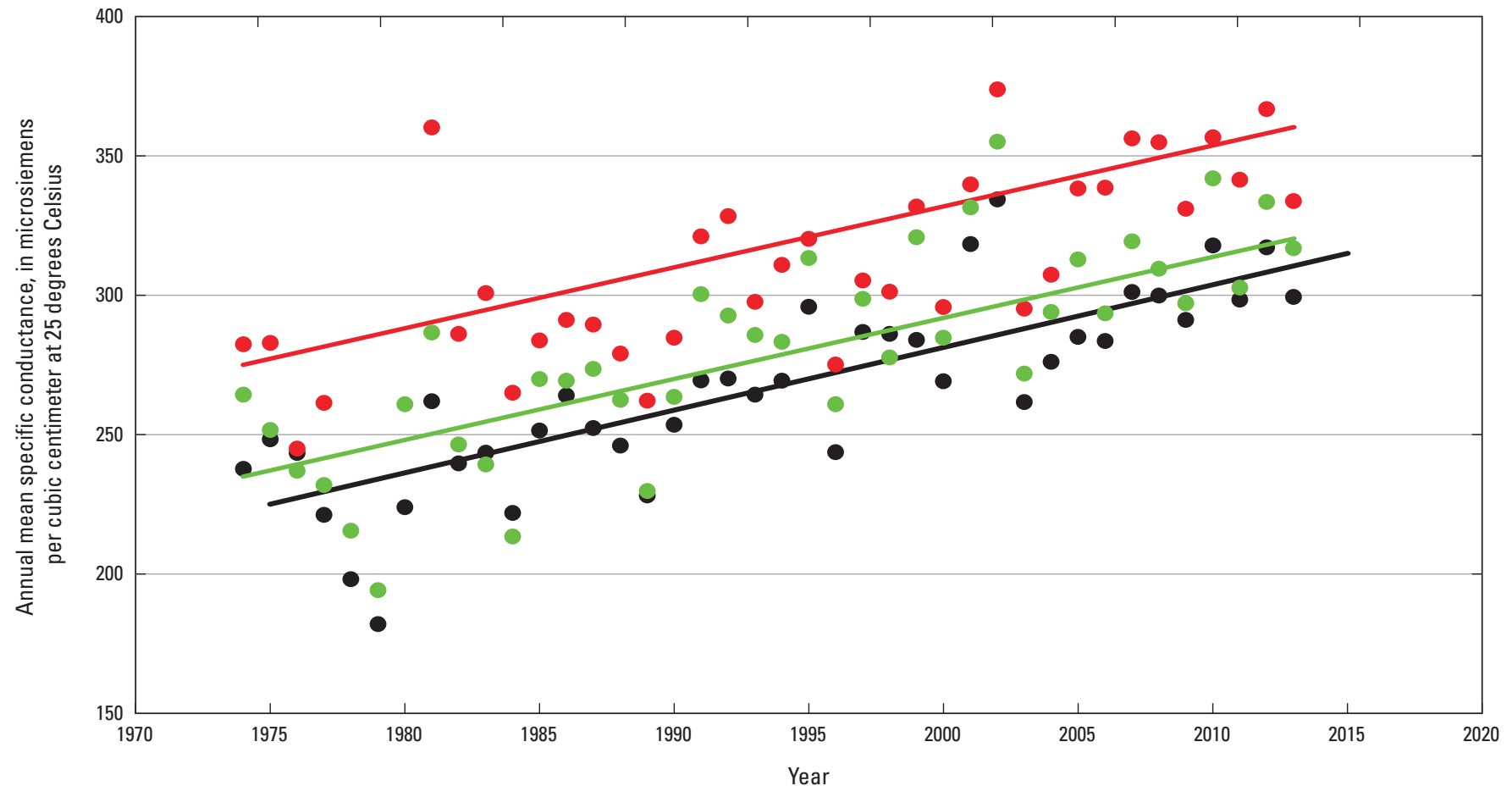

EXPLANATION

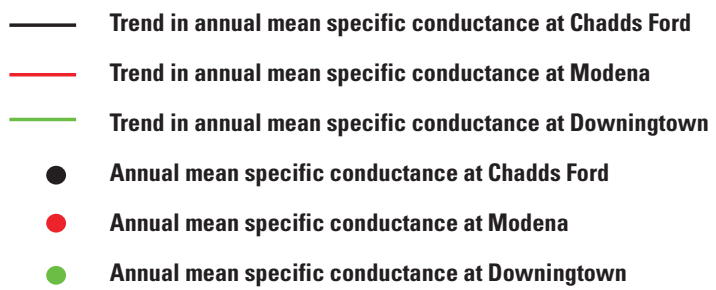

Figure 22. Annual mean specific conductance at stream water-quality stations 01481000, Brandywine Creek at Chadds Ford, Pennsylvania; 01480617, West Branch Brandywine Creek at Modena, Pennsylvania; and 01480870, East Branch Brandywine Creek below Downingtown, Pennsylvania, 1974-2013. 


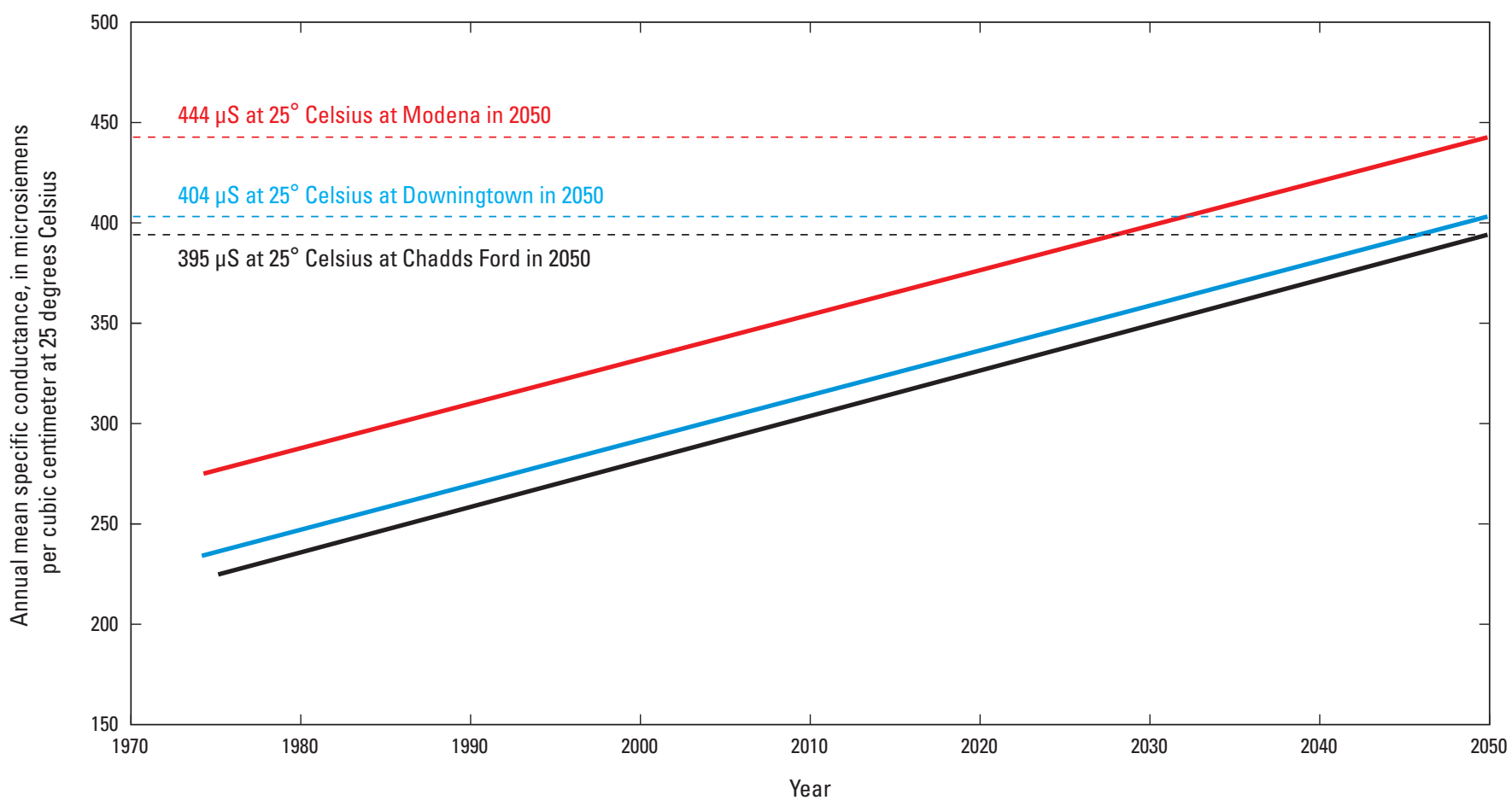

EXPLANATION

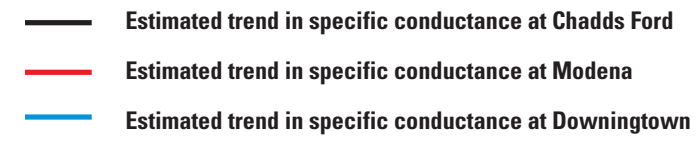

Figure 23. Estimated increase in annual mean specific conductance at stream water-quality stations 01481000 , Brandywine Creek at Chadds Ford, Pennsylvania; 01480617, West Branch Brandywine Creek at Modena, Pennsylvania; and 01480870, East Branch Brandywine Creek below Downingtown, Pennsylvania, 2014-50. $(\mu \mathrm{S} / \mathrm{cm}$ at 25 degrees Celsius, microsiemens per centimeter at 25 degrees Celsius)

Modena, Pa. (01480617) (table 17, fig. 26). The increase in dissolved oxygen concentration was $0.2 \mathrm{mg} / \mathrm{L}$ per decade.

Mean monthly values for specific conductance (fig. 27), $\mathrm{pH}$, and dissolved oxygen concentration (fig. 28) for 1974-2013 show identical patterns at all three stations. Mean monthly specific conductance decreases from March to April, reaching its lowest value in April. Mean monthly specific conductance increases from April to September, reaching its highest values then decreases from September to November (fig. 27). If the trend in mean monthly specific conductance continues, the mean September specific conductance could reach approximately $500 \mu \mathrm{S} / \mathrm{cm}$ at $25^{\circ} \mathrm{C}$ by 2050 (fig. 29).

The mean monthly dissolved oxygen concentration decreases from March to July, reaching its lowest concentration in July and August when biological activity that consumes oxygen is at its peak. The mean monthly dissolved oxygen concentration then increases from August to November (fig. 28). The decrease in dissolved oxygen concentration is partly the result of increasing stream temperatures. Cold water can hold more dissolved oxygen than warm water.
Monthly mean $\mathrm{pH}$ increases from March to April, declines from April to May, increases from May to August, and declines from August to November (fig. 28). Linear regression was used to determine whether a relation exists between monthly mean specific conductance and monthly mean streamflow or base flow (table 18). Virtually no correlation was found.

\section{Chester County Index of Biotic Integrity}

The Stream Conditions of Chester County Biological Monitoring Network was established by the CCWRA and the USGS in 1969. Trends in biological diversity index were evaluated by Moore (1987), Hardy and others (1995), and Reif (2012). For this study, the Chester County Index of Biotic Integrity (CC-IBI) data from 1998 to 2013 were used for statistical analysis. The CC-IBI was evaluated for the five biological sampling sites collocated with streamgages (table 19).

Benthic-macroinvertebrate data from the network from 1970 to 1980 were evaluated using the Brillouin's diversity 


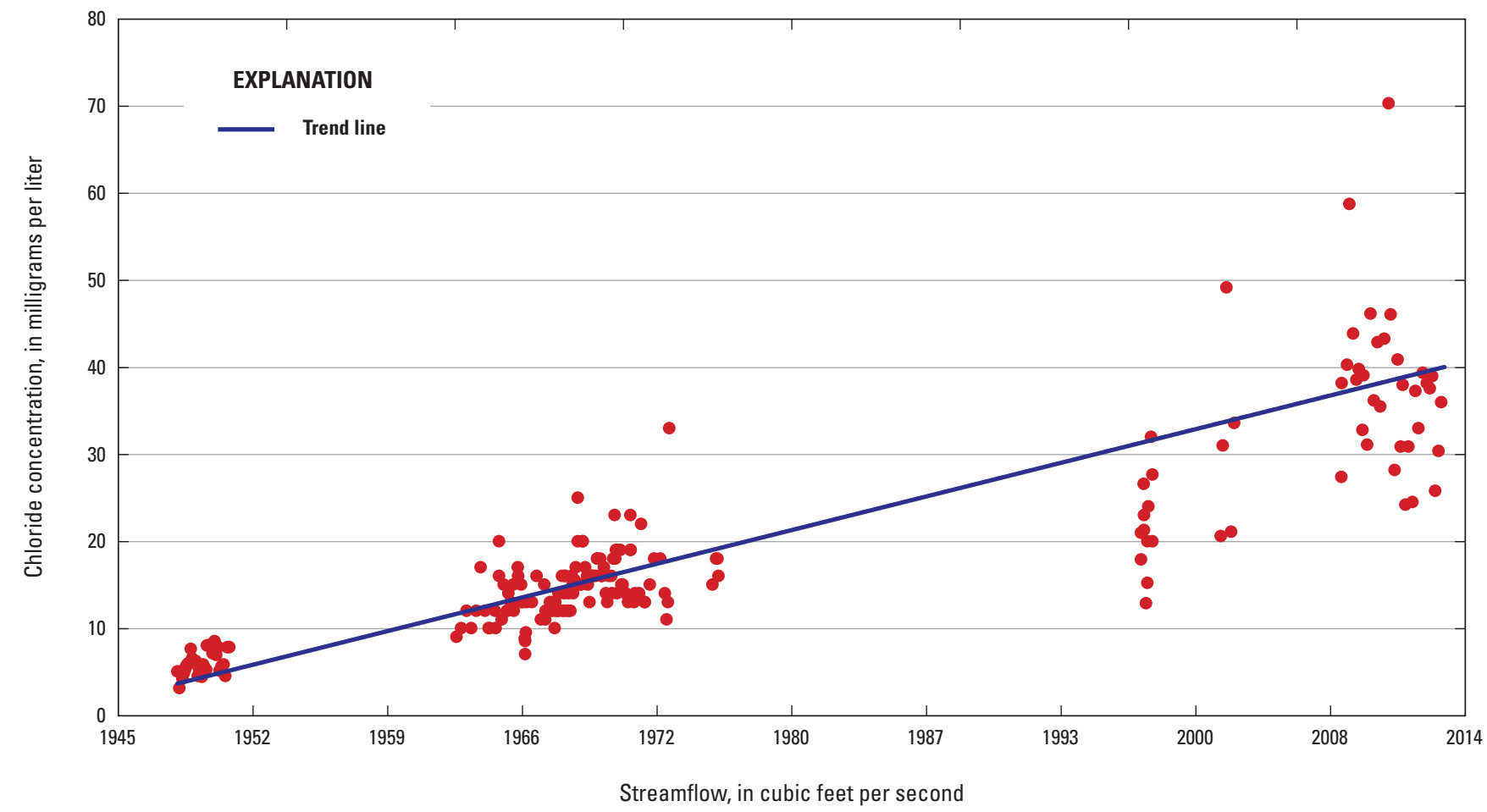

Figure 24. Chloride concentration in relation to streamflow at water-quality monitoring station 01481000 , Brandywine Creek at Chadds Ford, Pennsylvania, 1948-2013.

index (Moore, 1987), and data from 1981 to 1997 were evaluated using a multi-metric approach (Reif, 2002). Data from 1998 to 2009 were used to establish the CC-IBI, which is an index of biotic integrity that ranks community-level biological attributes (structure, composition, pollution tolerance, and diversity) in comparison to a reference or minimally disturbed condition. The CC-IBI consists of the six biological metricstotal taxa richness; modified Ephemeroptera, Plecoptera, Trichoptera (EPT) taxa richness; modified Hilsenhoff Biotic Index (HBI); Beck's Index (version 3); Shannon Diversity Index; and percent sensitive taxa. The CC-IBI scores are based on a $0-100$ scale with higher scores indicating better stream quality. The CC-IBI has site-specific scores that are based on benthicmacroinvertebrate samples collected from the network during 1998-2009 and related to reference conditions found in Chester County (Reif, 2012).

Statistically significant upward trends in the CC-IBI were observed at the two sites in the Brandywine Creek watershedWest Branch Brandywine Creek at Modena, Pa. (01480617) and East Branch Brandywine Creek below Downingtown, Pa. (01480870) (table 19, fig. 30). Because benthic macroinvertebrate communities act as integrators of the physical and chemical conditions, an upward trend in CC-IBI scores indicates improving water quality and (or) habitat conditions. No trend was observed for the remaining three sites listed in table 19.
Generally, extreme events, such as major storms and droughts, are thought to have the greatest effect on stream biota (Reif, 2002). Extreme events close to the sampling date are thought to have had the greatest effect on the macroinvertebrate community sampled in the study area. Samples collected after extreme low-flow or high-flow conditions generally had decreased CC-IBI (Reif, 2012).

Linear regression was used to determine whether a correlation exists between the CC-IBI for 1998-2013 and the (1) mean, minimum, and maximum daily streamflow in the 6 and 12 months prior to the day of sampling; (2) number of days streamflow was less than the 10th percentile ( 90 percent of streamflow was greater than the threshold) in the 6 months prior to the day of sampling; (3) most recent peak streamflow greater than a base; (4) number of days since the most recent peak streamflow greater than a base; (5) largest peak streamflow greater than a base during the 6 and 12 months prior to the day of sampling; (6) days since the largest peak streamflow greater than a base during the 6 and 12 months prior to the day of sampling; (7) total and maximum daily precipitation in the 6 and 12 months prior to the day of sampling; and (8) mean, minimum, and maximum monthly air temperature in the 6 and 12 months prior to the day of sampling. There was a poor correlation between the CC-IBI and all of these factors (tables 20 and 21). 


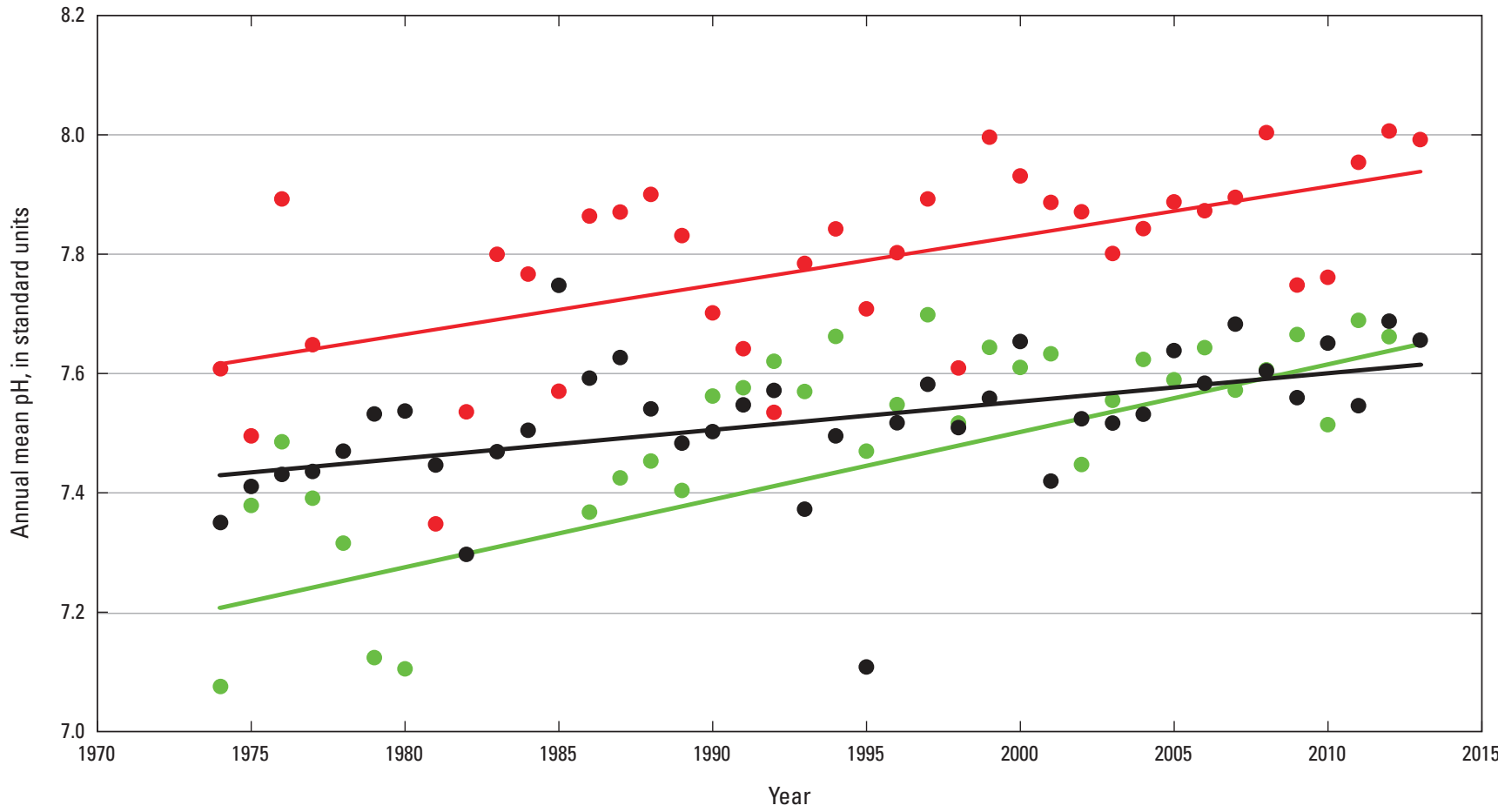

EXPLANATION

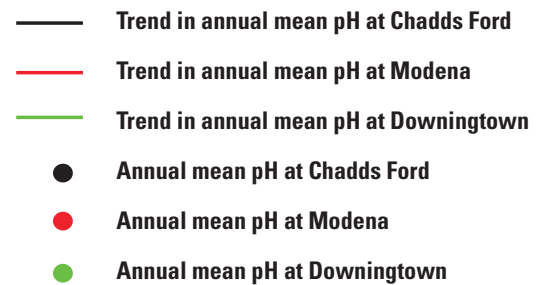

Figure 25. Annual mean pH at stream water-quality stations 01481000, Brandywine Creek at Chadds Ford, Pennsylvania; 01480617, West Branch Brandywine Creek at Modena, Pennsylvania; and 01480870, East Branch Brandywine Creek below Downingtown, Pennsylvania, 1974-2013.

Benthic macroinvertebrate sampling sites at stream water-quality monitoring stations East Branch Brandywine Creek below Downingtown, Pa. (01480870) and West Branch Brandywine Creek at Modena, Pa. (01480617) were selected to allow comparison of the CC-IBI and stream water quality. Linear regression was used to determine whether a correlation exists between the CC-IBI for 1998-2013 and the mean, minimum, and maximum stream water specific conductance, $\mathrm{pH}$, stream temperature, and dissolved oxygen concentration in the 6 months prior to the day of sampling. The CC-IBI correlated poorly with water-quality characteristics (table 22). Benthic macroinvertebrate communities are controlled by a multitude of factors beyond specific conductance, $\mathrm{pH}$, stream temperature, and dissolved oxygen concentration. Stream chemistry and physical features, such as stream bottom habitat and riparian conditions, have a great influence on the benthic macroinvertebrate community.

Results of most of the trend analyses conducted on the long-term streamflow, groundwater, precipitation, temperature, water-quality characteristics and benthic macroinvertebrate data indicated no significant trends. Significant trends in annual mean specific conductance and CC-IBI values had the largest slopes (1.033 to 2.289), indicating a relatively rapid change. Significant trends in all other characteristics had relatively small slopes ( 0.005 to 0.207$)$, indicating a relatively slow change (table 23). 


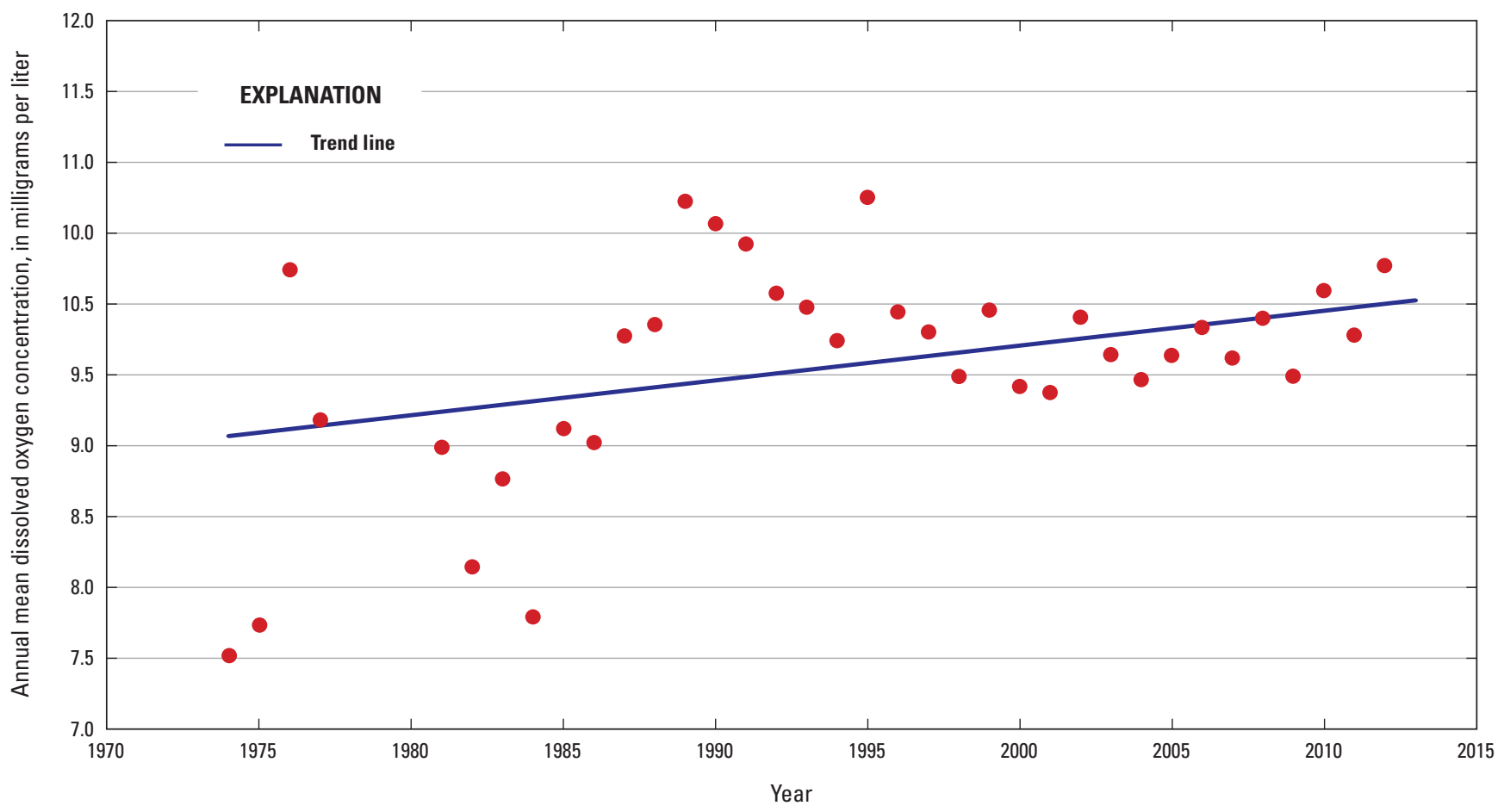

Figure 26. Annual mean dissolved oxygen concentration at water-quality station 01480617, West Branch Brandywine Creek at Modena, Pennsylvania, 1974-2013.

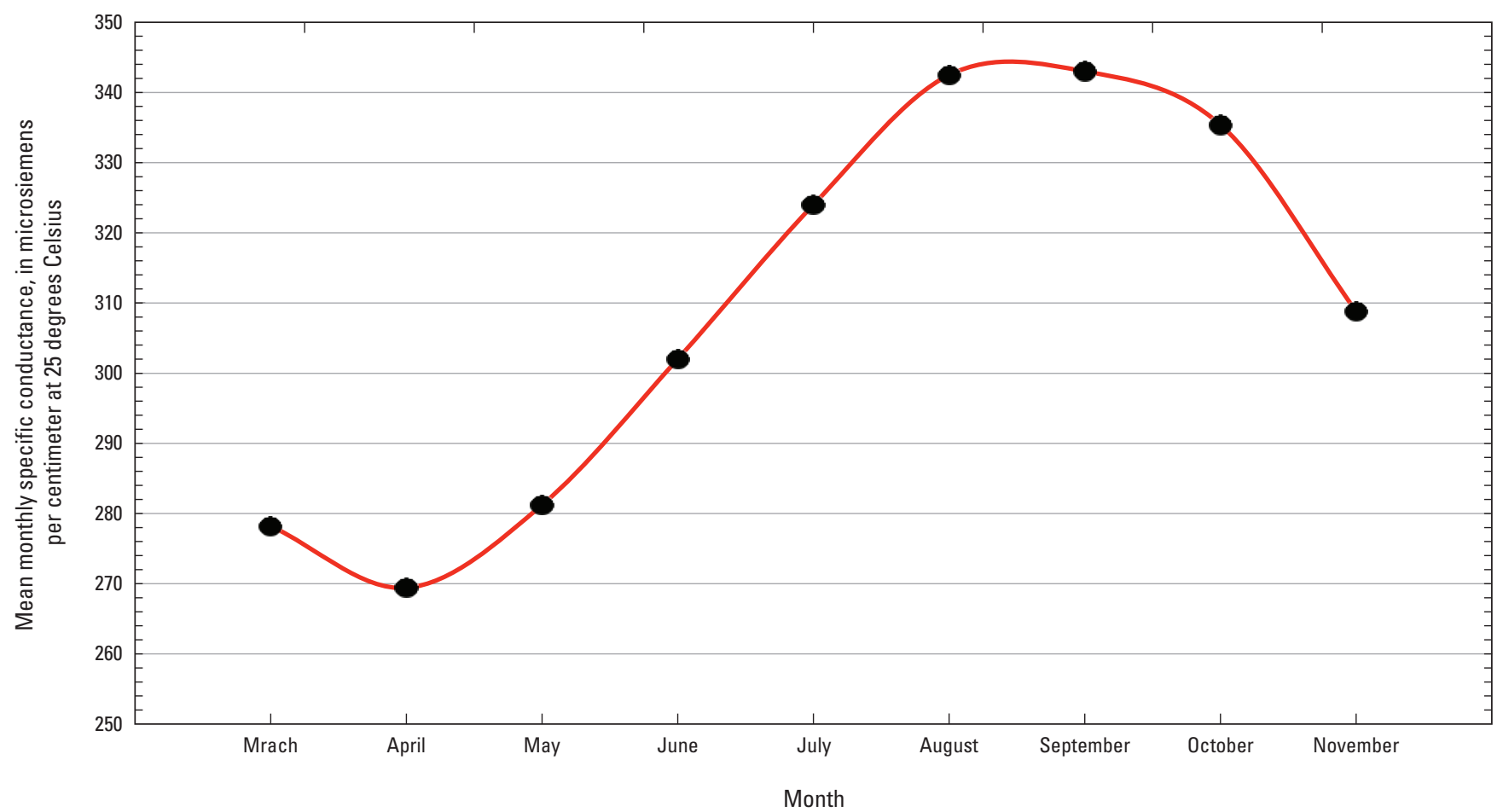

Figure 27. Mean monthly specific conductance at water-quality station 01480617, West Branch Brandywine Creek at Modena, Pennsylvania, 1974-2013. 


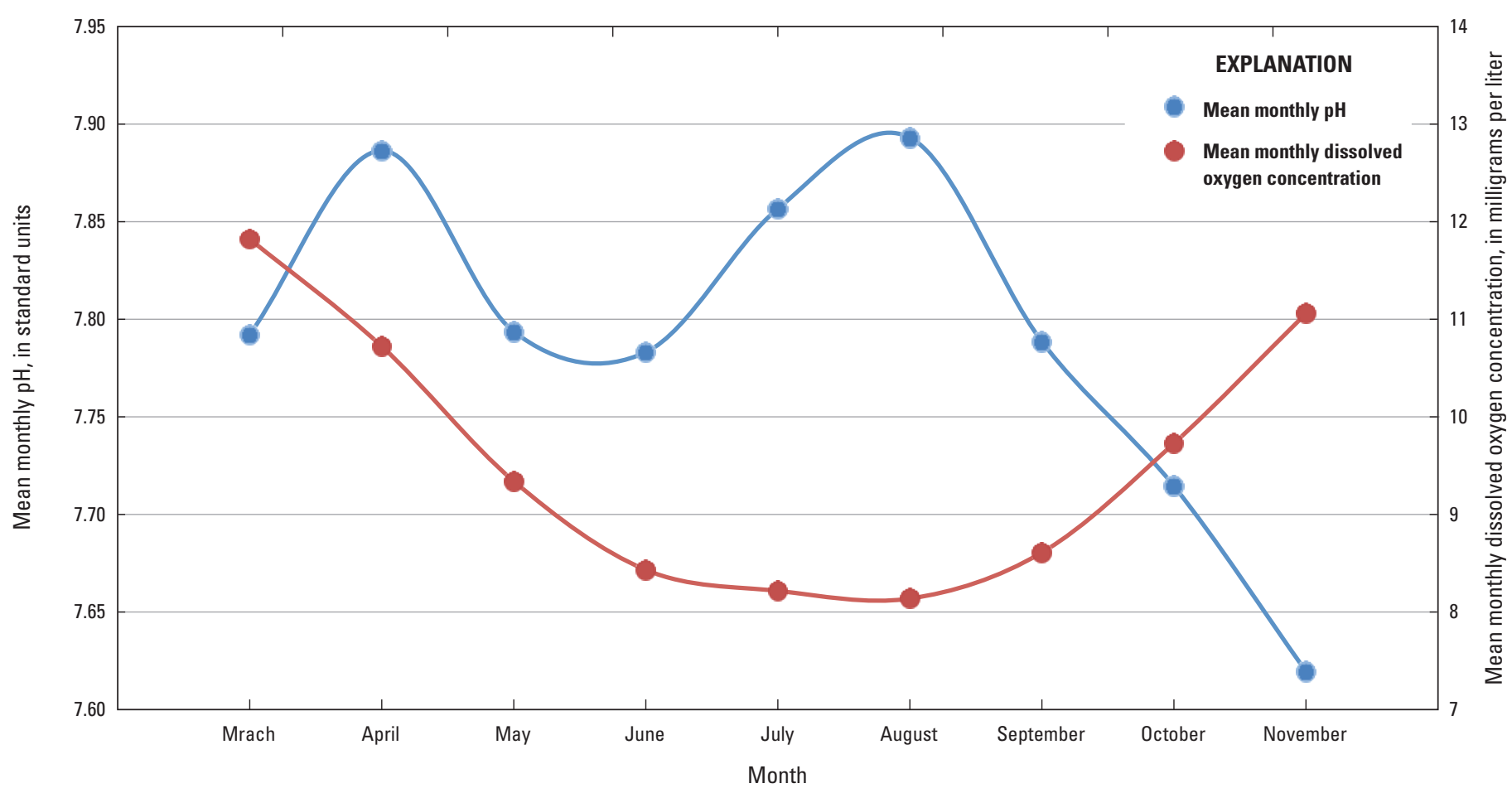

Figure 28. Mean monthly pH and dissolved oxygen concentration at water-quality station 01480617, West Branch Brandywine Creek at Modena, Pennsylvania, 1974-2013.

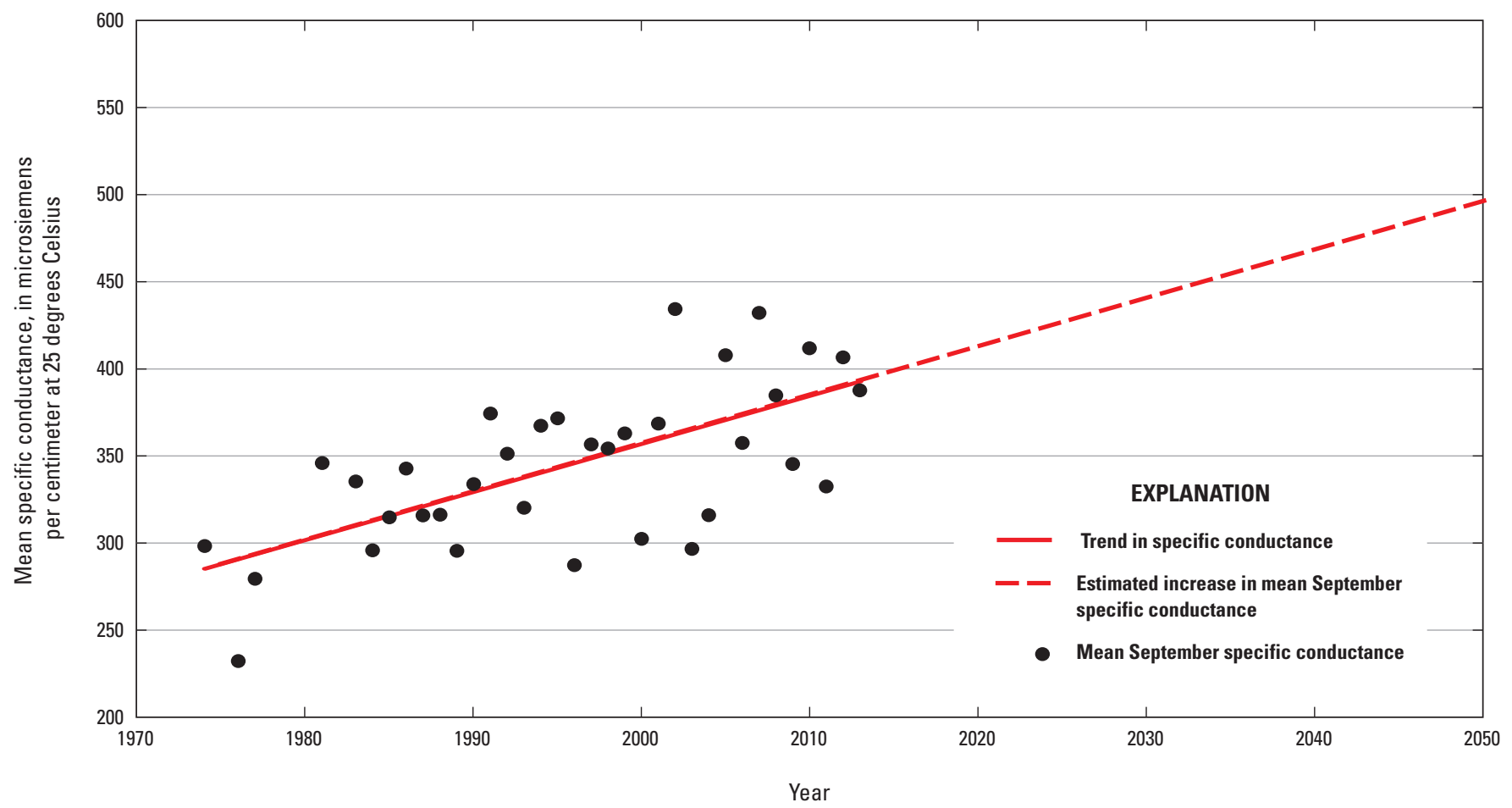

Figure 29. Estimated increase in mean September specific conductance at water-quality station 01480617, West Branch Brandywine Creek at Modena, Pennsylvania, 1974-2013, 2014-50. 
Table 18. Correlation between monthly mean specific conductance and monthly mean streamflow and base flow at selected waterquality monitoring stations in Chester County, Pennsylvania, 1974-2013.

[USGS, U.S. Geological Survey; numbers are the correlation coefficient, $\mathrm{r}^{2}$ ]

\begin{tabular}{|c|c|c|c|c|c|}
\hline \multirow{2}{*}{$\begin{array}{c}\text { USGS } \\
\text { station } \\
\text { number }\end{array}$} & \multirow{2}{*}{ Water-quality station } & \multicolumn{2}{|c|}{$\begin{array}{l}\text { Correlation with } \\
\text { monthly mean streamflow }\end{array}$} & \multicolumn{2}{|c|}{$\begin{array}{l}\text { Correlation with } \\
\text { monthly mean base flow }\end{array}$} \\
\hline & & Linear & Log transform & Linear & Log transform \\
\hline 01480617 & West Branch Brandywine Creek at Modena, Pa. & 0.2684 & 0.260 & 0.4031 & 0.3953 \\
\hline 01481000 & Brandywine Creek at Chadds Ford, Pa. & 0.2612 & 0.2612 & 0.3216 & 0.3277 \\
\hline
\end{tabular}

Table 19. Kendall $p$-values for trends in Chester County Index of Biotic Integrity at selected streamgages in Chester County, Pennsylvania, 1998-2013.

[USGS, U.S. Geological Survey; --, slope not significant; shading indicates significant trend; trends were considered significant if the p-value was less than 0.05; $\mathrm{p}$-value measures the significance of the trend, the lower the $\mathrm{p}$-value, the greater the statistical significance; mi ${ }^{2}$, square miles; CC-IBI, Chester County Index of Biotic Integrity]

\begin{tabular}{|c|c|c|c|c|c|}
\hline $\begin{array}{l}\text { USGS } \\
\text { station } \\
\text { number }\end{array}$ & Station name & $\begin{array}{c}\text { Drainage } \\
\text { area } \\
\left(\mathrm{mi}^{2}\right)\end{array}$ & $\begin{array}{l}\text { Water-quality } \\
\text { monitoring } \\
\text { station }\end{array}$ & $\begin{array}{c}\text { CC-IBI } \\
\text { p-value }\end{array}$ & Slope \\
\hline 01472157 & French Creek near Phoenixville, $\mathrm{Pa}$. & 59.1 & No & 0.235 & -- \\
\hline 01473169 & Valley Creek at PA Turnpike Br near Valley Forge, $\mathrm{Pa}$. & 20.8 & No & 0.235 & -- \\
\hline 01480617 & West Branch Brandywine Creek at Modena, Pa. & 55.0 & Yes & 0.003 & 1.821 \\
\hline 01480870 & East Branch Brandywine Creek below Downingtown, $\mathrm{Pa}$. & 89.9 & Yes & 0.023 & 1.033 \\
\hline
\end{tabular}

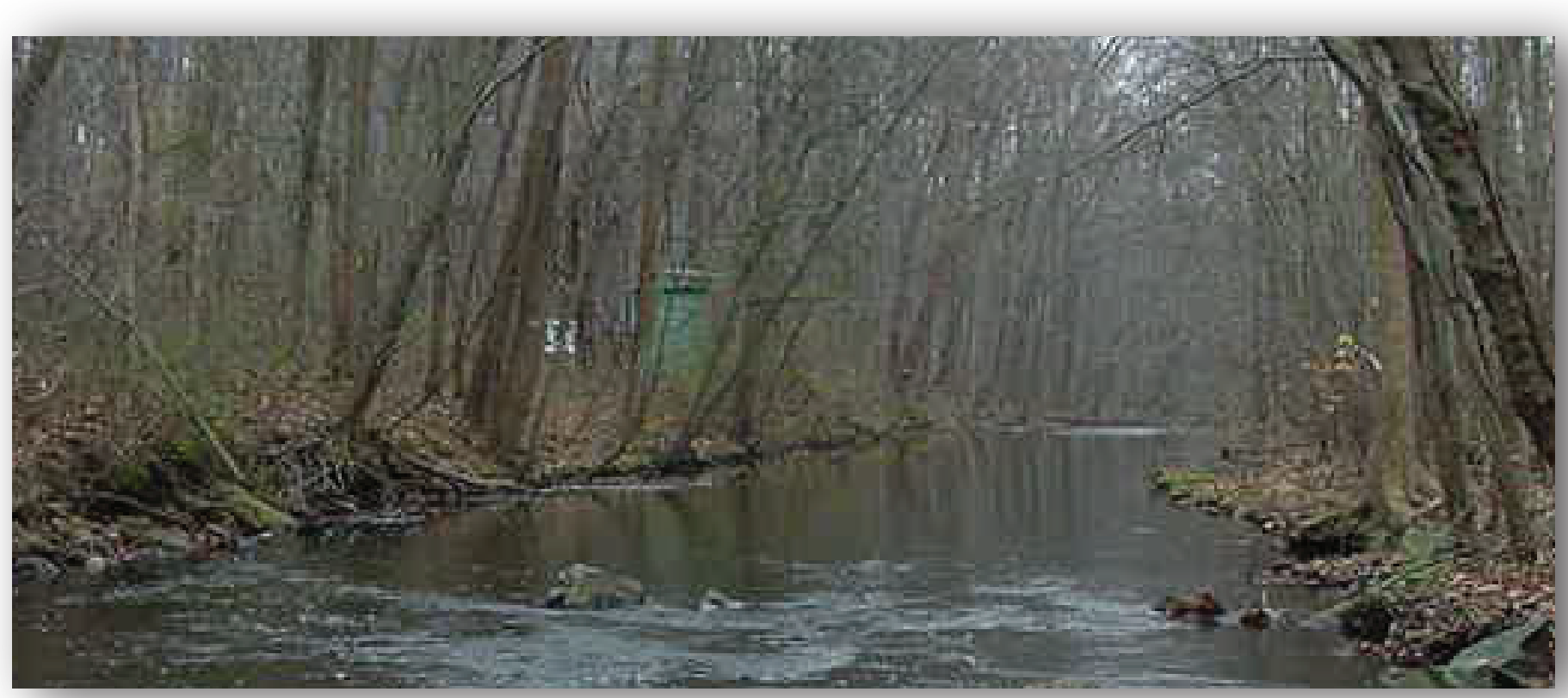

Photo of Marsh Creek near Glenmoore, Pa. (Photograph provided by Andrew Reif, U.S. Geological Survey) 


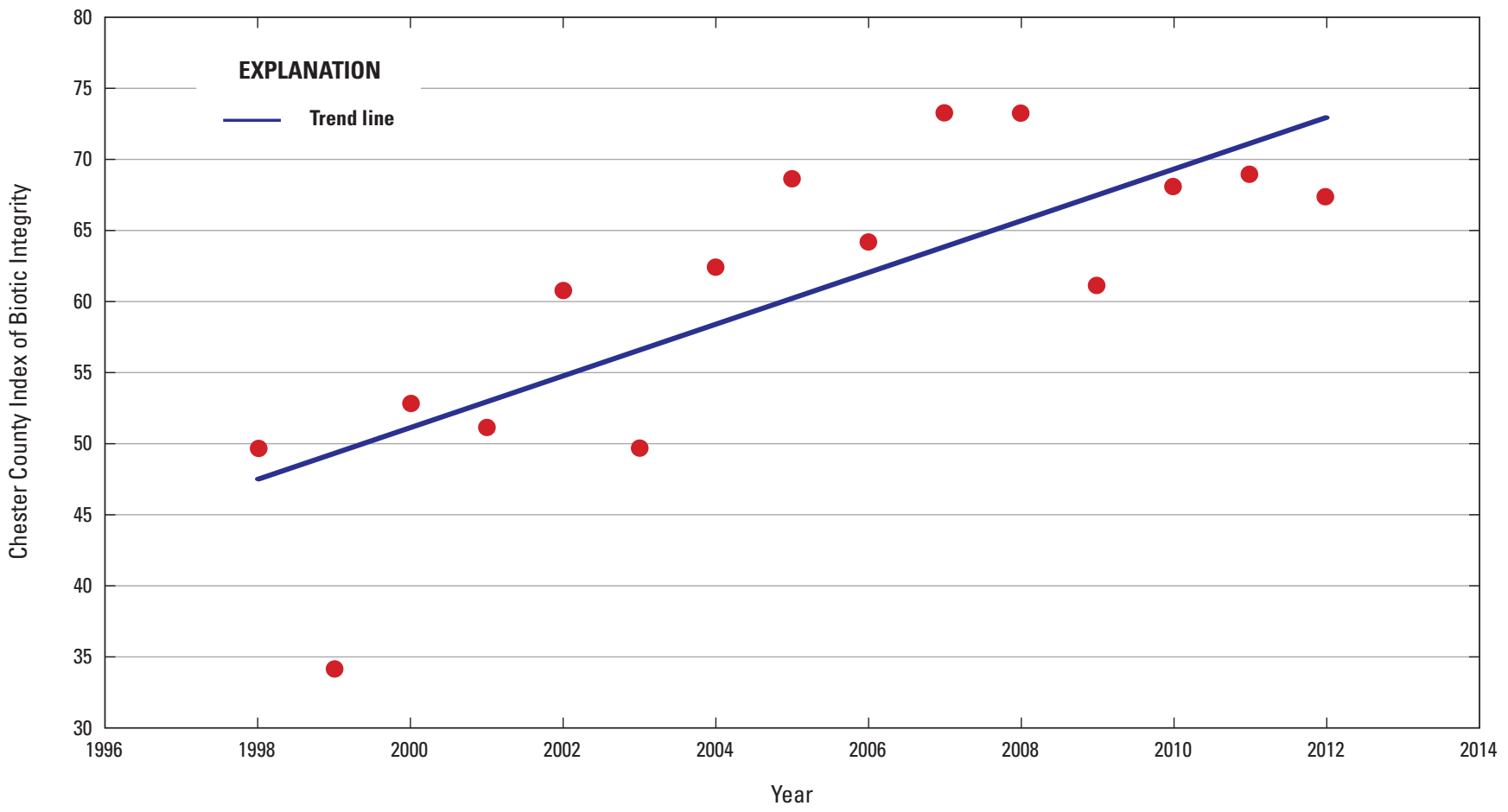

Figure 30. Chester County Index of Biotic Integrity at station 01480870, East Branch Brandywine Creek below Downingtown, Pennsylvania, 1998-2013.

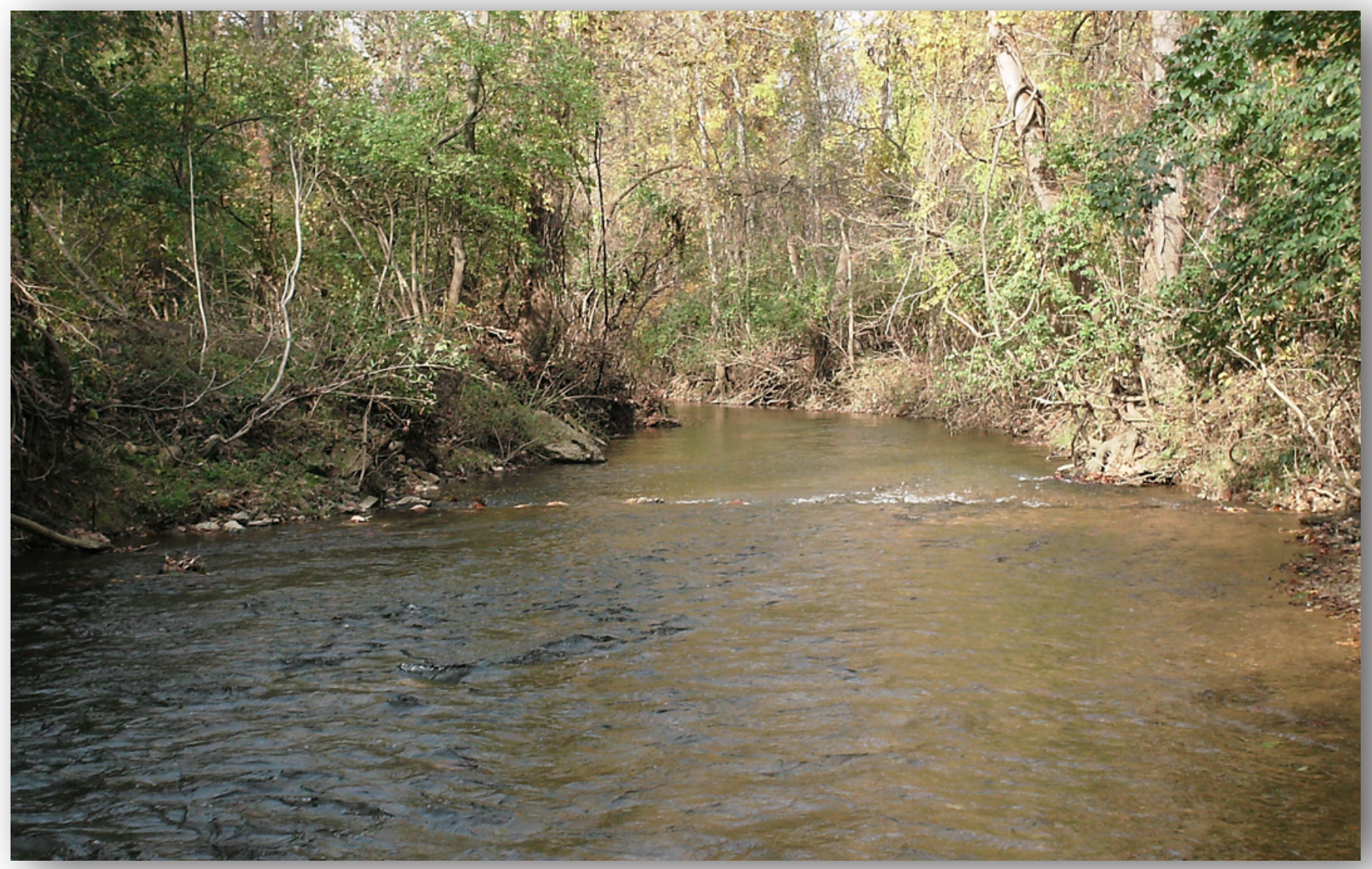



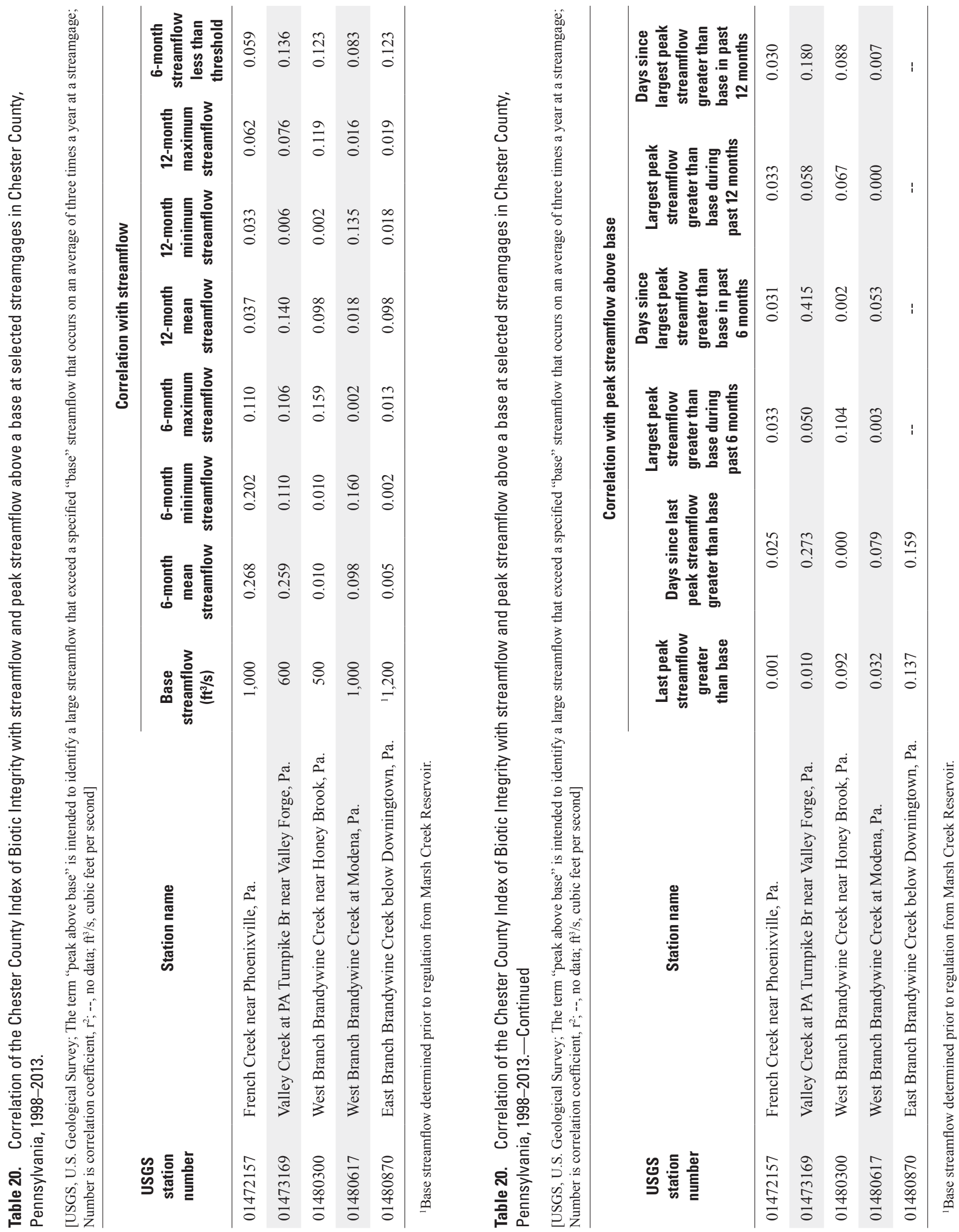

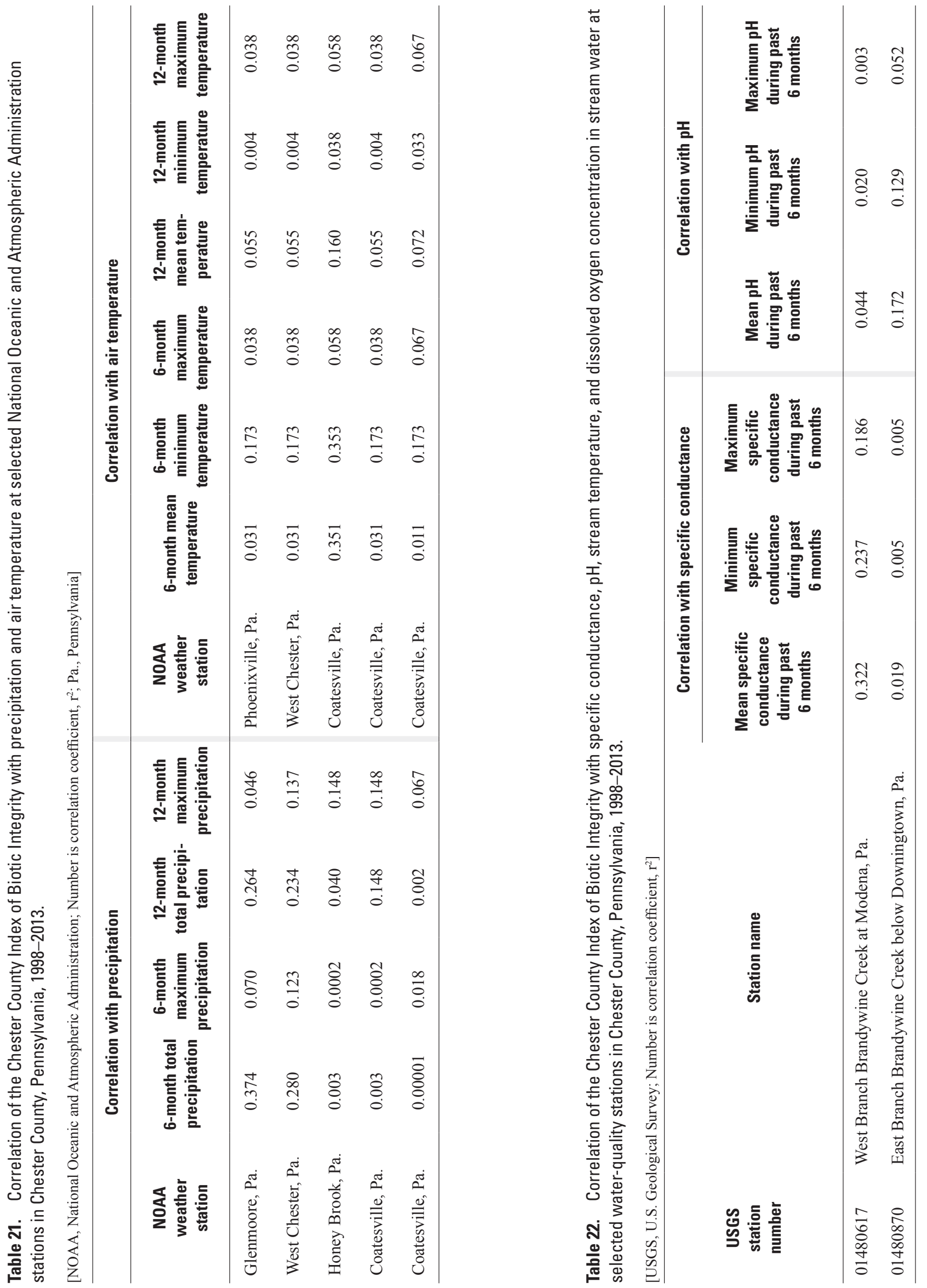

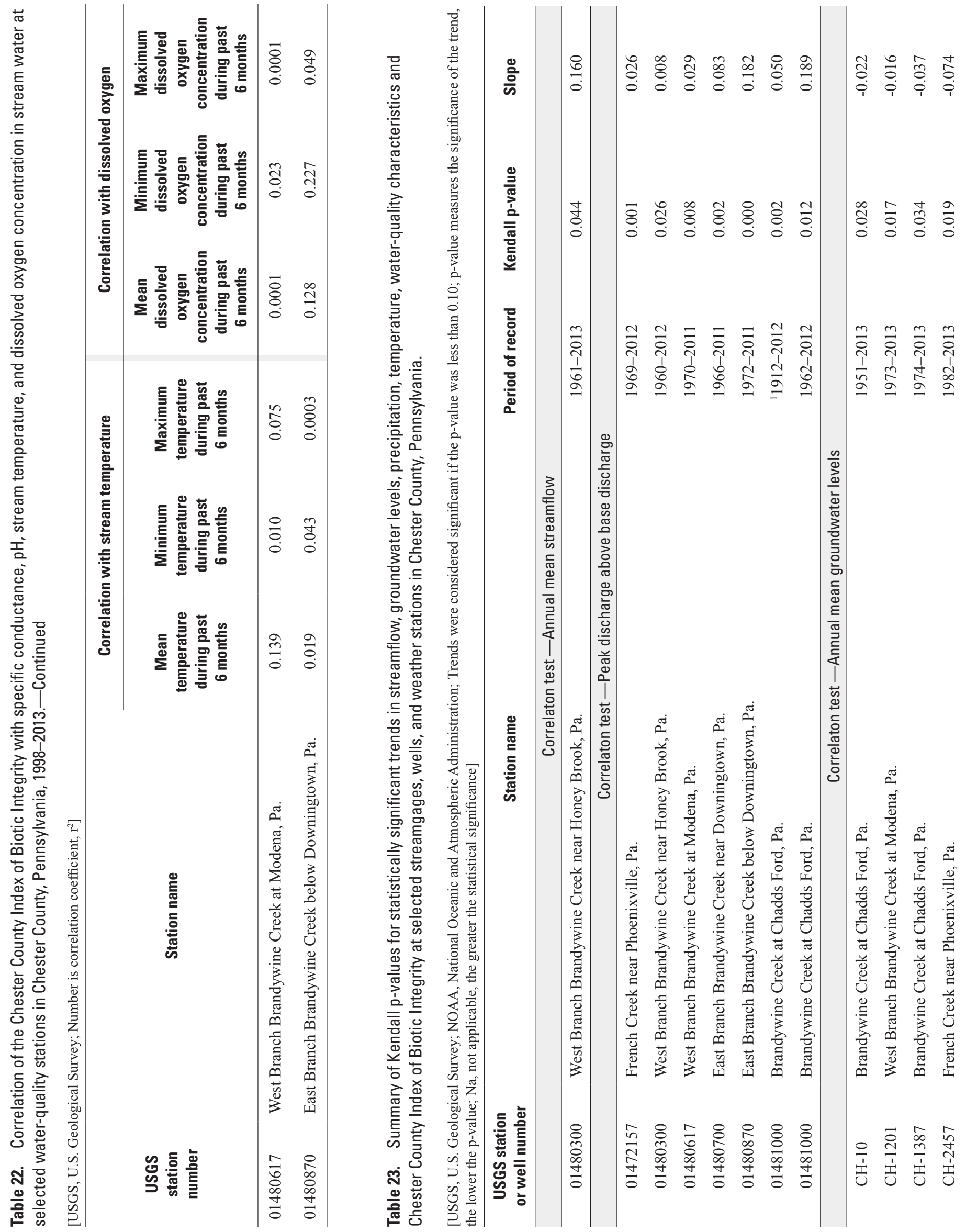


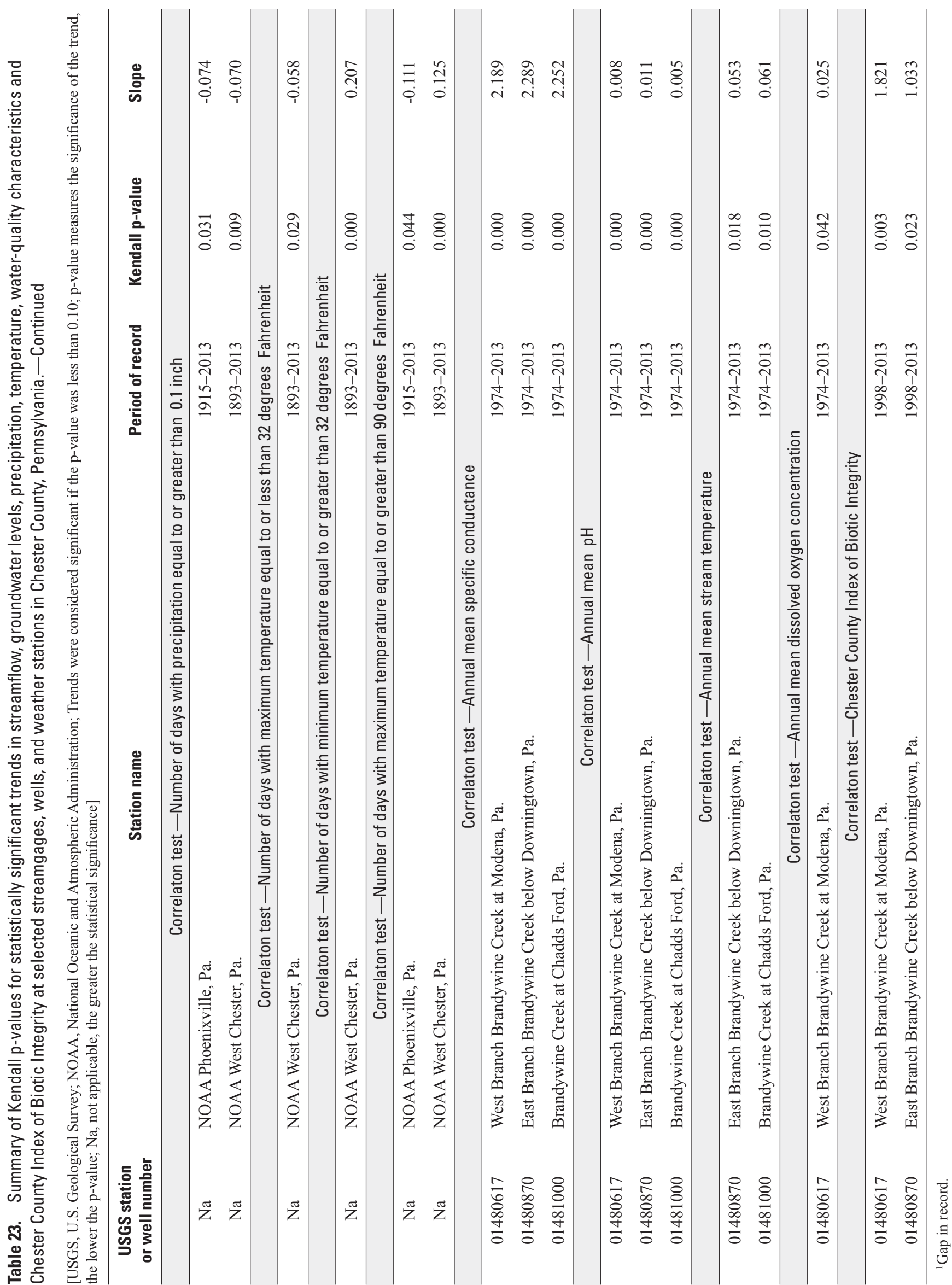




\section{Estimation of Water Budgets through 2013}

Water budgets were previously developed for several Chester County watersheds through cooperative projects with the CCWRA (Cinotto and others, 2005; Sloto, 1994; Sloto, 2002; Vogel and Reif, 1993) and the Delaware River Basin Commission (Sloto, 2004; Sloto and Buxton, 2005). For this study, those water budgets were extended through 2013. In addition, a water budget was developed for the Marsh Creek watershed (fig. 31).

A water budget was developed for French Creek upstream from streamgage 01472157 (French Creek near Phoenixville) for 1969-2013 (table 24). Annual precipitation ranged from 33 in. to $67 \mathrm{in}$. with an average of $47 \mathrm{in.}$. Annual streamflow ranged from 9 in. to 37 in. with an average of $21 \mathrm{in}$. Annual streamflow ranged from 22 percent of precipitation to 61 percent of precipitation with an average of 44 percent. Annual runoff ranged from 3 in. to 16 in. with an average of 8 in. Annual base flow ranged from 6 in. to 20 in. with an average of $13 \mathrm{in.}$ Annual base flow ranged from 53 percent of streamflow to 73 percent of streamflow with an average of 61 percent. Annual base flow ranged from 14 percent of precipitation to 37 percent of precipitation with an average of 27 percent. The annual change in groundwater storage ranged from a loss of $5 \mathrm{in}$. to a gain of $4 \mathrm{in}$. with an average change of 0.1 in. Annual evapotranspiration plus estimation errors ranged from 19 in. to $30 \mathrm{in}$. with an average of $26 \mathrm{in.}$

A water budget was developed for Red Clay Creek upstream from streamgage 01479820 (Red Clay Creek near Kennett Square) for 1988-2013 (table 25). Annual precipitation ranged from 34 in. to $75 \mathrm{in.} \mathrm{with} \mathrm{an} \mathrm{average} \mathrm{of} 51 \mathrm{in.}$ Annual streamflow ranged from 12 in. to 38 in. with an average of $21 \mathrm{in.} \mathrm{Annual} \mathrm{streamflow} \mathrm{ranged} \mathrm{from} 26$ percent of precipitation to 58 percent of precipitation with an average of 41 percent. Annual runoff ranged from 3 in. to 20 in. with an average of $7 \mathrm{in}$. Annual base flow ranged from $7 \mathrm{in}$. to $21 \mathrm{in}$. with an average of $13 \mathrm{in}$. Annual base flow ranged from 48 percent of streamflow to 82 percent of streamflow with an average of 65 percent. Annual base flow ranged from 17 percent of precipitation to 38 percent of precipitation with an average of 27 percent. The annual change in groundwater storage ranged from a loss of $5 \mathrm{in}$. to a gain of $7 \mathrm{in}$. with an average change of 0 in. Imports of water into the watershed were obtained from the Chester Water Authority. Imports of water into the watershed ranged from 3 in. to 4 in. with an average of 3 in. Annual evapotranspiration plus estimation errors ranged from 21 in. to $42 \mathrm{in.}$ with an average of $33 \mathrm{in.}$

A water budget was developed for West Branch Brandywine Creek upstream from streamgage 01480300 (West Branch Brandywine Creek near Honey Brook) for 1974-2013 (table 26). Annual precipitation ranged from 29 in. to 64 in. with an average of 46 in. Annual streamflow ranged from 9 in. to 41 in. with an average of $21 \mathrm{in.} \mathrm{Annual} \mathrm{streamflow} \mathrm{ranged}$ from 26 percent of precipitation to 69 percent of precipitation with an average of 45 percent. Annual runoff ranged from 3 in. to $21 \mathrm{in}$. with an average of $9 \mathrm{in}$. Annual base flow ranged from 6 in. to 20 in. with an average of 12 in. Annual base flow ranged from 41 percent of streamflow to 74 percent of streamflow with an average of 57 percent. Annual base flow ranged from 14 percent of precipitation to 36 percent of precipitation with an average of 25 percent. The annual change in groundwater storage ranged from a loss of 4 in. to a gain of 4 in. with an average change of 0 in. Annual evapotranspiration plus estimation errors ranged from 18 in. to 31 in. with an average of 25 in.

A water budget was developed for West Branch Brandywine Creek upstream from streamgage 01480617 (West Branch Brandywine Creek at Modena) for 1978-2013 (table 27). Annual precipitation ranged from 34 in. to 67 in. with an average of $48 \mathrm{in}$. Annual streamflow ranged from $10 \mathrm{in.}$ to $37 \mathrm{in}$. with an average of $21 \mathrm{in.} \mathrm{Annual} \mathrm{streamflow}$ ranged from 25 percent of precipitation to 58 percent of precipitation with an average of 42 percent. Annual base flow ranged from $7 \mathrm{in.} \mathrm{to} 19 \mathrm{in.}$ with an average of $13 \mathrm{in.}$ Annual base flow ranged from 51 percent of streamflow to 74 percent of streamflow in with an average of 62 percent. Annual runoff ranged from $3 \mathrm{in.}$ to $18 \mathrm{in}$. with an average of $8 \mathrm{in.} \mathrm{Annual}$ base flow ranged from 15 percent of precipitation to 34 percent of precipitation with an average of 26 percent. The annual change in groundwater storage ranged from a loss of $4 \mathrm{in.}$ to a gain of $5 \mathrm{in}$. with an average change of $0 \mathrm{in}$. The annual change in surface-water storage (Chambers Lake) ranged from a decrease of 0.2 in. to an increase of 0.2 in. with an average change of 0 in. Annual evapotranspiration, import/export estimates and estimation errors ranged from 17 in. to 36 in. with an average of $28 \mathrm{in.}$

A water budget for Broad Run upstream from streamgage 01480638 (Broad Run at Northbrook) was presented by Cinotto and others (2005, p. 21) for April 2003 to March 2004. An annual (January 1 to December 31 ) water budget for Broad Run upstream from the streamgage for 2005-13 is presented in table 28. Annual precipitation ranged from 47 in. to $69 \mathrm{in}$. with an average of $53 \mathrm{in.} \mathrm{Annual} \mathrm{streamflow} \mathrm{ranged}$ from $17 \mathrm{in.} \mathrm{to} 30 \mathrm{in}$. with an average of $22 \mathrm{in.} \mathrm{Annual} \mathrm{stream-}$ flow ranged from 35 percent of precipitation to 49 percent of precipitation with an average of 42 percent. Annual base flow ranged from 13 in. to 22 in. with an average of 16 in. Annual runoff ranged from 3 in. to $9 \mathrm{in}$. with an average of 6 in. Annual base flow ranged from 71 percent of streamflow to 79 percent of streamflow with an average of 75 percent. Annual base flow ranged from 28 percent of precipitation to 37 percent of precipitation with an average of 31 percent. The annual change in groundwater storage ranged from a loss of $4 \mathrm{in}$. to a gain of $3 \mathrm{in}$. with an average change of 0 in. Annual evapotranspiration plus estimation errors ranged from 24 in. to $36 \mathrm{in.}$ with an average of $30 \mathrm{in}$.

A water budget was developed for Marsh Creek upstream from streamgage 01480675 (Marsh Creek near Glenmoore) for 1974-2013 (table 29). Annual precipitation ranged from $34 \mathrm{in}$. to $69 \mathrm{in}$. with an average of $49 \mathrm{in}$. Annual streamflow 


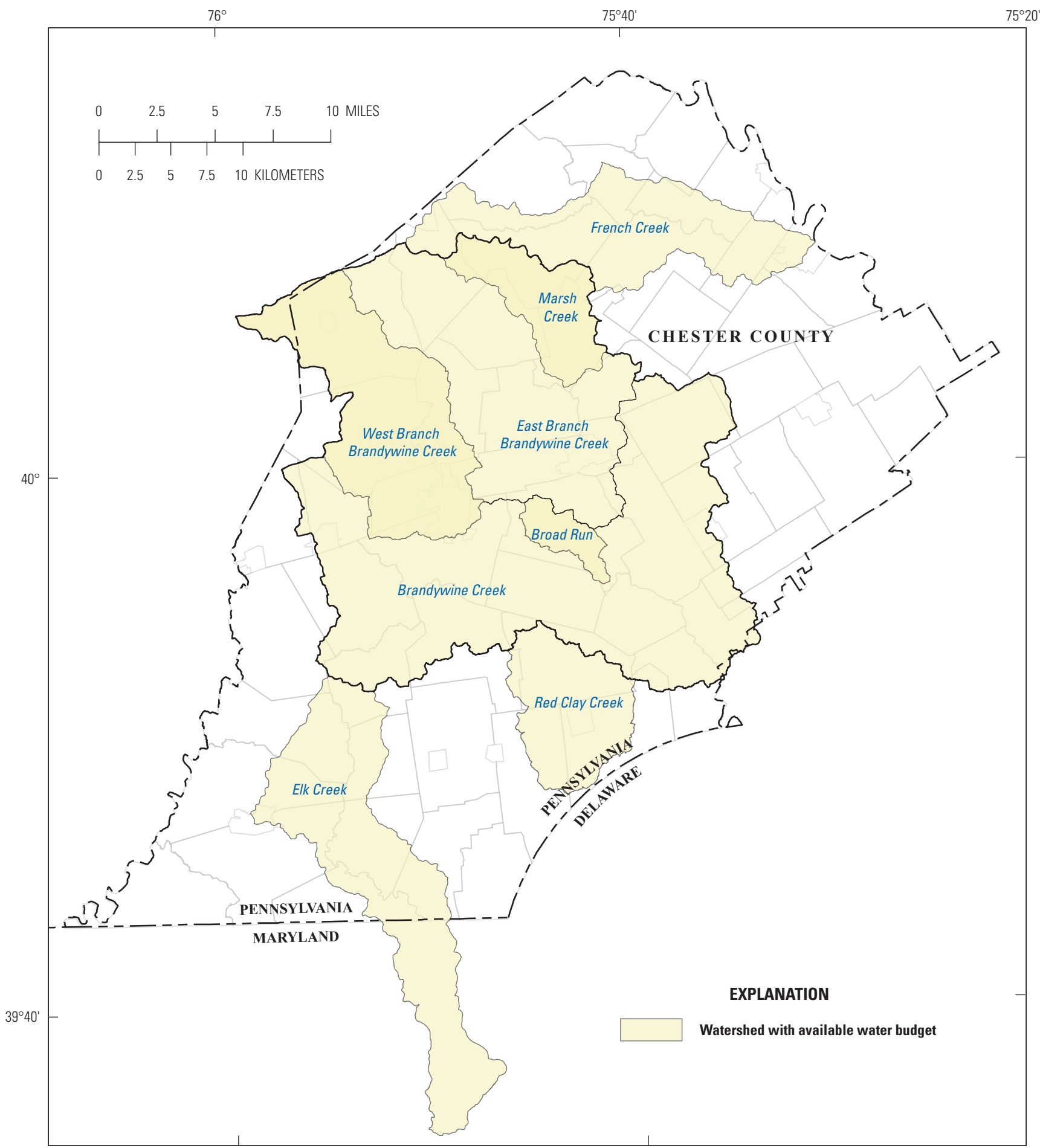

Base from U.S. Geological Survey digital data, 1972, 1:2,000,000 Albers Equal-Area Conic Projection. Standard paralleis $29^{\circ} 30^{\prime} \mathrm{N}$, central meridian $75^{\circ} 00^{\prime} \mathrm{W}$

Figure 31. Watersheds with available water budgets, Chester County, Pennsylvania. 
Table 24. Water budget for French Creek watershed upstream from streamgage 01472157, French Creek near Phoenixville, Pennsylvania, 1969-2013.

[Values are in inches per year. Negative change indicates a decrease in groundwater storage. Positive change indicates an increase in groundwater storage]

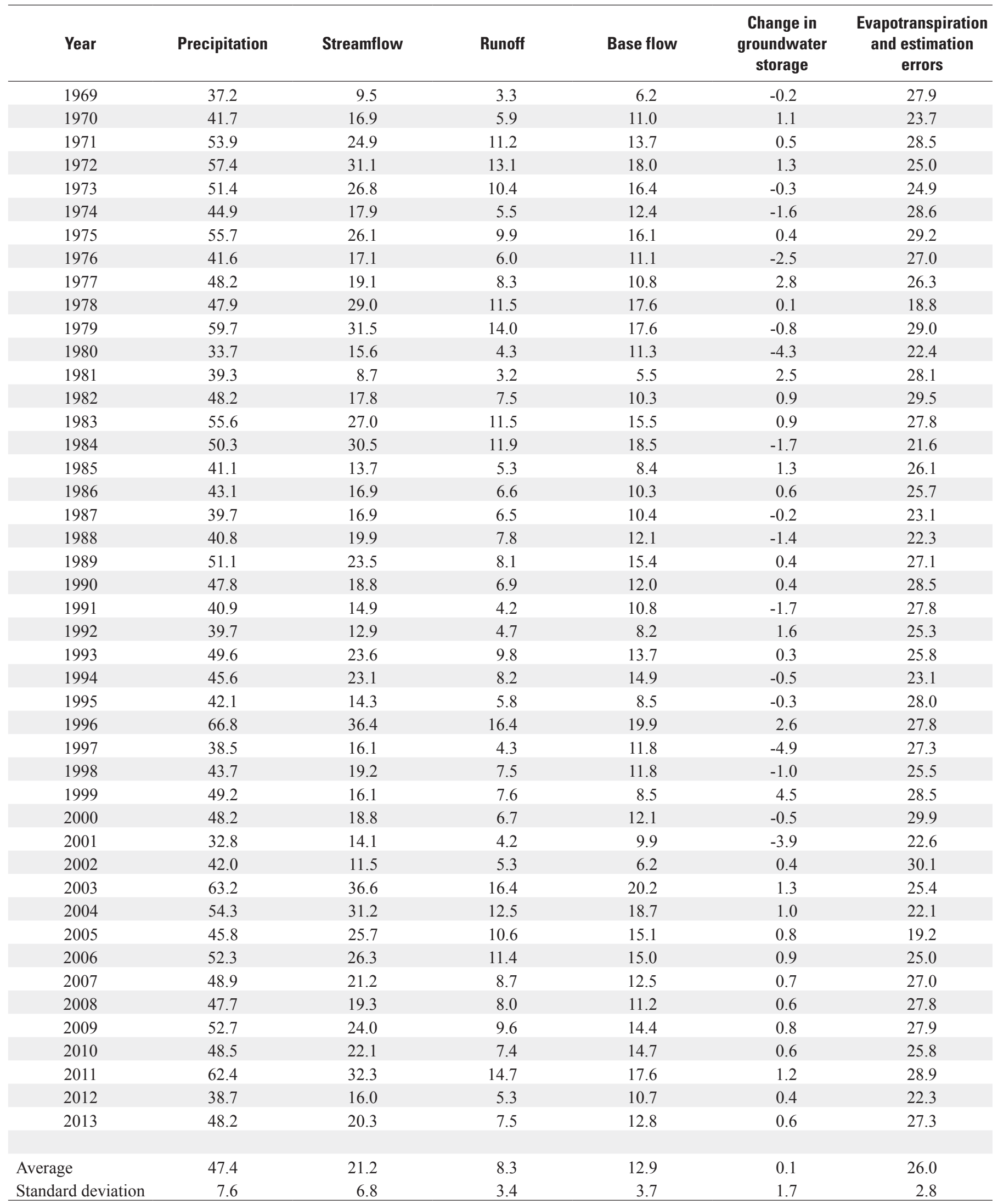


Table 25. Water budget for Red Clay Creek watershed upstream from streamgage 01479820, Red Clay Creek near Kennett Square, Pennsylvania, 1988-2013.

[Values are in inches per year. Negative change indicates a decrease in groundwater storage. Positive change indicates an increase in groundwater storage. Dark shading indicates imported water data were estimated]

\begin{tabular}{|c|c|c|c|c|c|c|c|}
\hline Year & Precipitation & Streamflow & Runoff & Base flow & $\begin{array}{l}\text { Change in } \\
\text { groundwater } \\
\text { storage }\end{array}$ & $\begin{array}{l}\text { Imported }{ }^{1} \\
\text { water }\end{array}$ & $\begin{array}{l}\text { Evapotranspiration } \\
\text { and estimation } \\
\text { errors }\end{array}$ \\
\hline 1988 & 43.9 & 16.4 & 5.1 & 11.2 & -1.1 & 3.4 & 32.0 \\
\hline 1989 & 50.1 & 24.4 & 8.8 & 15.6 & 3.2 & 3.4 & 25.9 \\
\hline 1990 & 35.7 & 19.8 & 6.1 & 13.8 & -1.4 & 3.4 & 20.7 \\
\hline 1991 & 36.1 & 14.8 & 4.2 & 10.6 & -3.0 & 3.4 & 27.7 \\
\hline 1992 & 47.4 & 12.5 & 3.4 & 9.1 & 1.3 & 3.4 & 36.9 \\
\hline 1993 & 56.2 & 22.2 & 8.8 & 13.4 & 1.5 & 3.4 & 35.8 \\
\hline 1994 & 50.2 & 19.5 & 6.2 & 13.3 & -2.6 & 3.4 & 36.7 \\
\hline 1995 & 47.3 & 12.2 & 4.1 & 8.2 & 0.9 & 3.4 & 37.5 \\
\hline 1996 & 75.1 & 31.4 & 13.2 & 18.1 & 5.0 & 3.5 & 42.3 \\
\hline 1997 & 39.4 & 16.9 & 3.0 & 13.9 & -4.9 & 3.5 & 30.9 \\
\hline 1998 & 45.1 & 14.0 & 3.7 & 10.4 & -1.4 & 3.2 & 35.7 \\
\hline 1999 & 52.1 & 17.5 & 8.0 & 9.6 & 0.5 & 3.2 & 37.2 \\
\hline 2000 & 51.1 & 19.4 & 6.8 & 12.6 & 1.2 & 3.3 & 33.7 \\
\hline 2001 & 33.9 & 14.7 & 5.4 & 9.4 & -1.6 & 3.4 & 24.2 \\
\hline 2002 & 44.9 & 12.1 & 4.6 & 7.5 & -0.2 & 2.9 & 35.9 \\
\hline 2003 & 71.5 & 38.0 & 19.7 & 18.3 & 7.0 & 3.4 & 30.0 \\
\hline 2004 & 62.5 & 36.0 & 15.0 & 21.0 & -0.4 & 3.5 & 30.4 \\
\hline 2005 & 46.6 & 25.2 & 7.4 & 17.8 & -3.4 & 3.7 & 28.5 \\
\hline 2006 & 50.3 & 20.2 & 7.3 & 12.9 & -0.1 & 3.6 & 33.8 \\
\hline 2007 & 51.5 & 21.0 & 7.5 & 13.5 & -1.4 & 3.6 & 35.6 \\
\hline 2008 & 46.7 & 17.2 & 5.0 & 12.2 & -0.7 & 3.6 & 33.8 \\
\hline 2009 & 56.3 & 23.3 & 8.4 & 15.0 & 3.0 & 3.5 & 33.5 \\
\hline 2010 & 52.2 & 24.0 & 7.7 & 16.3 & -2.0 & 3.5 & 33.8 \\
\hline 2011 & 69.2 & 29.5 & 12.2 & 17.2 & 2.1 & 3.5 & 41.1 \\
\hline 2012 & 47.7 & 16.2 & 4.5 & 11.7 & -3.4 & 3.4 & 38.2 \\
\hline 2013 & 53.4 & 22.4 & 7.9 & 14.5 & 2.3 & 3.4 & 32.2 \\
\hline Average & 50.6 & 20.8 & 7.5 & 13.3 & 0.0 & 3.4 & 33.2 \\
\hline Standard deviation & 10.4 & 7.0 & 3.9 & 3.5 & 2.7 & 0.2 & 5.0 \\
\hline
\end{tabular}

${ }^{1}$ Imported water data were obtained from the Chester Water Authority. 
Table 26. Water budget for West Branch Brandywine Creek watershed upstream from streamgage 01480300, West Branch Brandywine Creek near Honey Brook, Pennsylvania, 1974-2013.

[Values are in inches per year. Negative change indicates a decrease in groundwater storage. Positive change indicates an increase in groundwater storage]

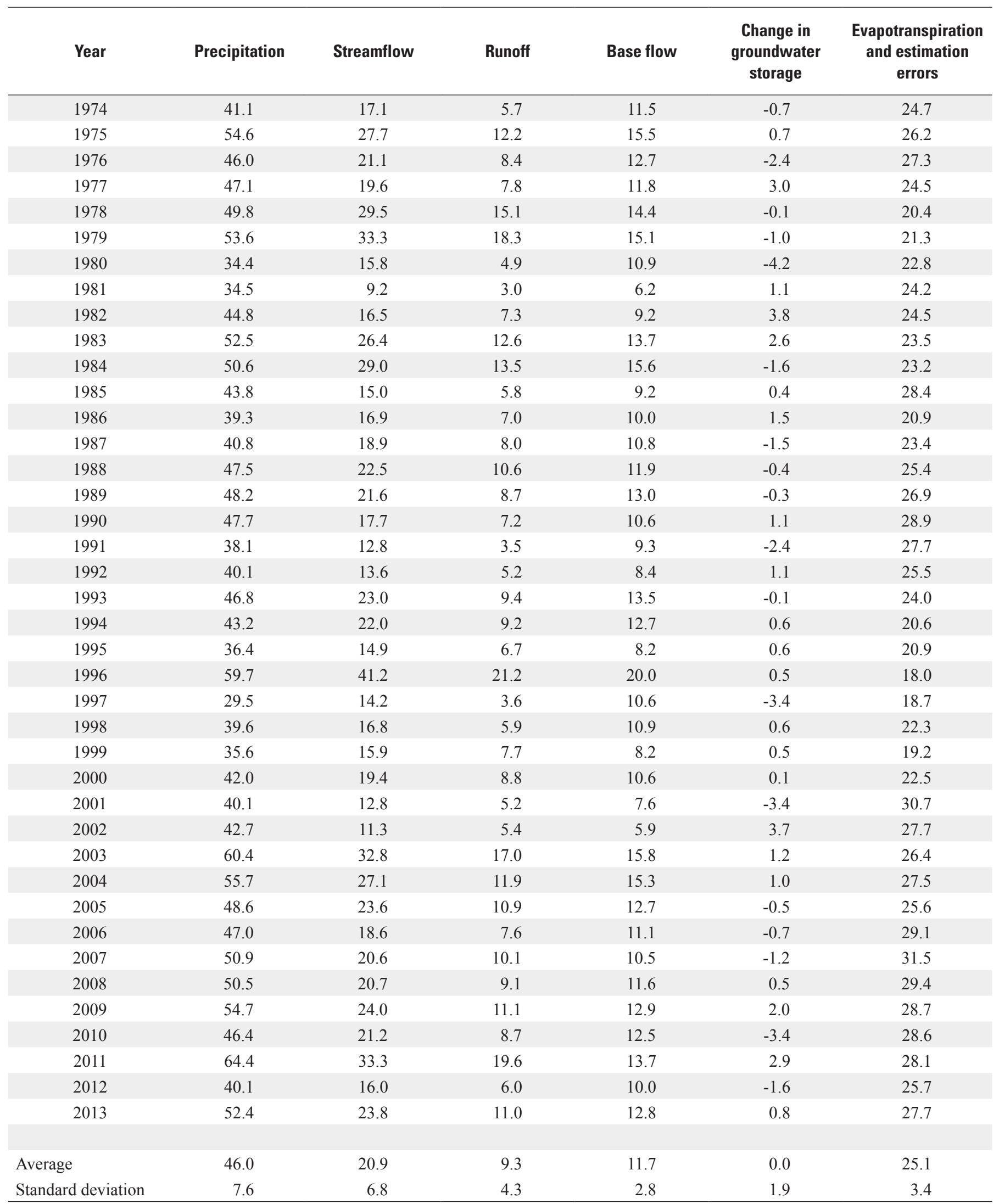


Table 27. Water budget for West Branch Brandywine Creek watershed upstream from streamgage 01480617, West Branch Brandywine Creek at Modena, Pennsylvania, 1978-2013.

[Values are in inches per year. Negative change indicates a decrease in groundwater storage. Positive change indicates an increase in groundwater or surfacewater storage]

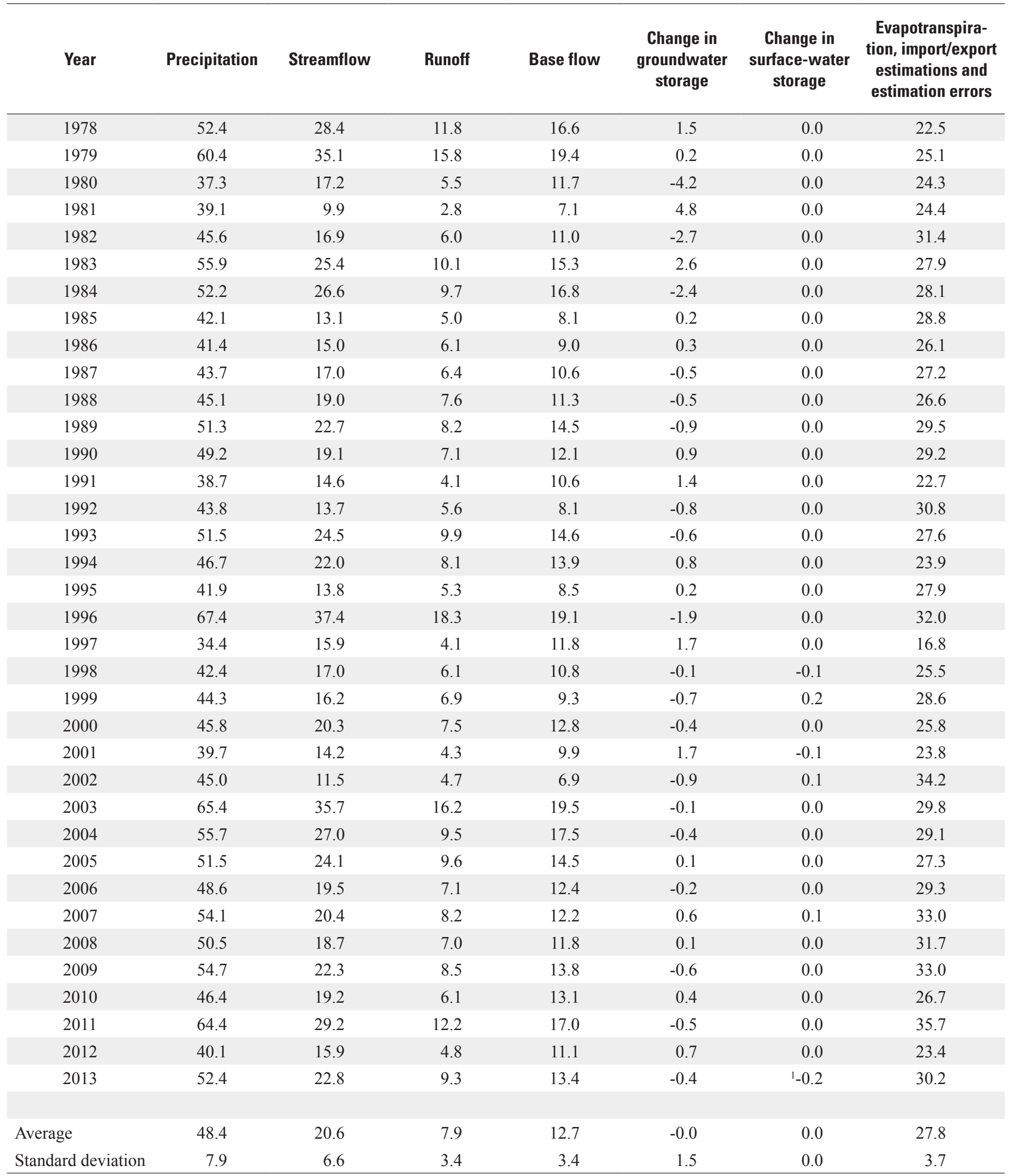

${ }^{1}$ Missing data from September 18 to November 7, 2013. 
Table 28. Water budget for Broad Run watershed upstream from streamgage 01480638, Broad Run at Northbrook, Pennsylvania, 2005-13.

[Values are in inches per year. Negative change indicates a decrease in groundwater storage. Positive change indicates an increase in groundwater storage]

\begin{tabular}{ccccccc}
\hline Year & Precipitation & Streamflow & Runoff & Base flow & $\begin{array}{c}\text { Change in } \\
\text { groundwater } \\
\text { storage }\end{array}$ & $\begin{array}{c}\text { Evapotranspiration } \\
\text { and estimation } \\
\text { errors }\end{array}$ \\
\hline 2005 & 46.6 & 22.9 & 5.6 & 17.3 & -0.6 & 24.3 \\
2006 & 50.3 & 20.3 & 5.9 & 14.4 & -1.3 & 31.3 \\
\hline 2007 & 51.5 & 24.5 & 7.1 & 17.4 & 0.1 & 26.9 \\
\hline 2008 & 46.7 & 17.9 & 4.0 & 13.9 & 0.4 & 28.4 \\
\hline 2009 & 56.3 & 21.8 & 5.9 & 15.9 & 1.1 & 33.4 \\
\hline 2010 & 52.2 & 22.1 & 4.8 & 17.3 & -2.1 & 32.3 \\
\hline 2011 & 69.2 & 30.2 & 8.6 & 21.6 & 2.4 & 36.5 \\
\hline 2012 & 47.7 & 16.7 & 3.5 & 13.2 & -3.8 & 34.8 \\
\hline 2013 & 53.4 & 23.6 & 6.1 & 17.5 & 2.8 & 27.0 \\
\hline Average & & & & & & 30.5 \\
\hline Standard deviation & 52.7 & 22.2 & 5.7 & 16.5 & -0.1 & 3.9 \\
\hline
\end{tabular}

ranged from 8 in. to 38 in. with an average of 21 in. Annual streamflow ranged from 21 percent of precipitation to 56 percent of precipitation with an average of 42 percent. Annual runoff ranged from 3 in. to $20 \mathrm{in.} \mathrm{with} \mathrm{an} \mathrm{average}$ of 9 in. Annual base flow ranged from 5 in. to 19 in. with an average of $12 \mathrm{in.}$. Annual base flow ranged from 47 percent of streamflow to 70 percent of streamflow with an average of 56 percent. Annual base flow ranged from 12 percent of precipitation to 31 percent of precipitation with an average of 23 percent. The annual change in groundwater storage ranged from a loss of 6 in. to a gain of 6 in. with an average change of 0 in. Annual evapotranspiration plus estimation errors ranged from 23 in. to 33 in. with an average of 28 in.

A water budget was developed for East Branch Brandywine Creek upstream from streamgage 01480870 (East Branch Brandywine Creek below Downingtown) for 1977-2013 (table 30). Annual precipitation ranged from 35 in. to 69 in. with an average of $49 \mathrm{in}$. Annual streamflow ranged from $10 \mathrm{in.} \mathrm{to} 41 \mathrm{in}$. with an average of $23 \mathrm{in.}$. Annual streamflow ranged from 25 percent of precipitation to 62 percent of precipitation with an average of 46 percent. Annual runoff ranged from 3 in. to $17 \mathrm{in}$. with an average of $8 \mathrm{in}$. Base flow is affected by releases from Marsh Creek Reservoir. Annual base flow ranged from 7 in. to $25 \mathrm{in}$. with an average of $15 \mathrm{in}$. Annual base flow ranged from 58 percent of streamflow to 78 percent of streamflow with an average of 65 percent. Annual base flow ranged from 18 percent of precipitation to 39 percent of precipitation with an average of 30 percent. The annual change in groundwater storage ranged from a loss of $4 \mathrm{in}$. to a gain of $6 \mathrm{in}$. with an average change of $0 \mathrm{in}$. The annual change in storage in Marsh Creek Reservoir ranged from a decrease of $0.7 \mathrm{in}$. to an increase of $1.0 \mathrm{in}$. with an average change of $0 \mathrm{in}$. Annual evapotranspiration, import/ export estimations, and estimation errors ranged from 23 in. to $35 \mathrm{in}$. with an average of $26 \mathrm{in}$.

A water budget was developed for the Brandywine Creek upstream from streamgage 01481000 (Brandywine Creek at Chadds Ford) for 1963-2013 (table 31). Annual precipitation ranged from $34 \mathrm{in}$. to $70 \mathrm{in}$. with an average of $48 \mathrm{in}$. Annual streamflow ranged from $10 \mathrm{in.}$ to $41 \mathrm{in}$. with an average of $21 \mathrm{in}$. Annual streamflow ranged from 24 percent of precipitation to 61 percent of precipitation with an average of 42 percent. Annual runoff ranged from 3 in. to 18 in. with an average of $7 \mathrm{in.}$. Base flow may be affected by releases from Marsh Creek Reservoir, which began operating in 1973. Annual base flow ranged from $7 \mathrm{in}$. to $24 \mathrm{in}$. with an average of $13 \mathrm{in.}$ Annual base flow ranged from 55 percent of streamflow to 77 percent of streamflow with an average of 65 percent. Annual base flow ranged from 15 percent of precipitation to 39 percent of precipitation with an average of 27 percent. The annual change in groundwater storage ranged from a loss of $5 \mathrm{in}$. to a gain of $5 \mathrm{in}$. in 1996 with an average change of 0 in. The annual change in surface-water storage (Marsh Creek Reservoir and Chambers Lake) in the watershed ranged from a decrease of 0.2 in. in 1988 to an increase of 0.7 in. in 1974 with an average change of 0 in. during 1973 to 2013. Annual 
Table 29. Water budget for Marsh Creek watershed upstream from streamgage 01480675, Marsh Creek near Glenmoore, Pennsylvania, 1974-2013.

[Values are in inches per year. Negative change indicates a decrease in groundwater storage. Positive change indicates an increase in groundwater storage]

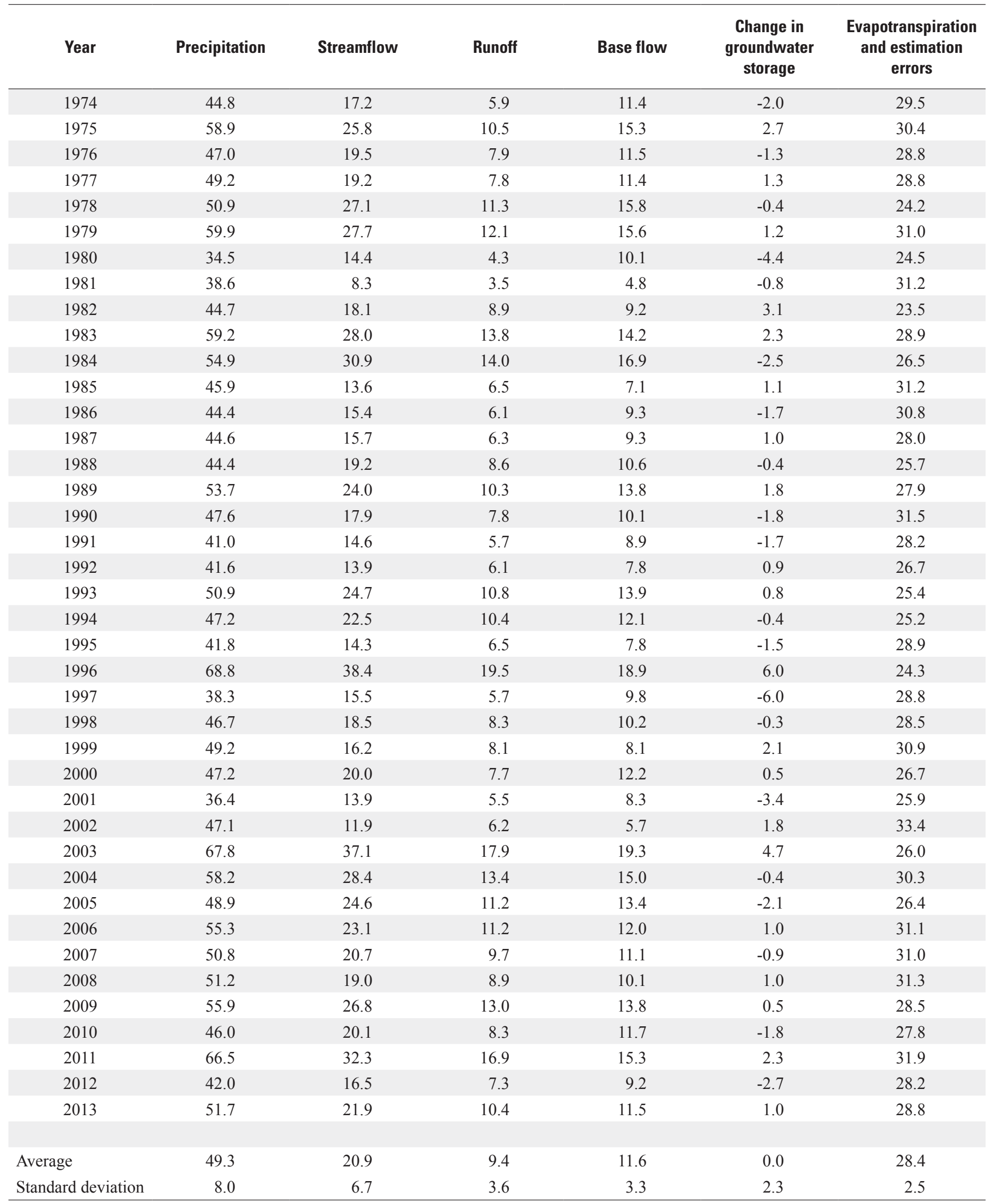


Table 30. Water budget for East Branch Brandywine Creek watershed above streamgage 01480870, East Branch Brandywine Creek below Downingtown, Pennsylvania, 1977-2013.

[Values are in inches per year. Negative change indicates a decrease in groundwater or surface-water storage. Positive change indicates an increase in groundwater or surface-water storage]

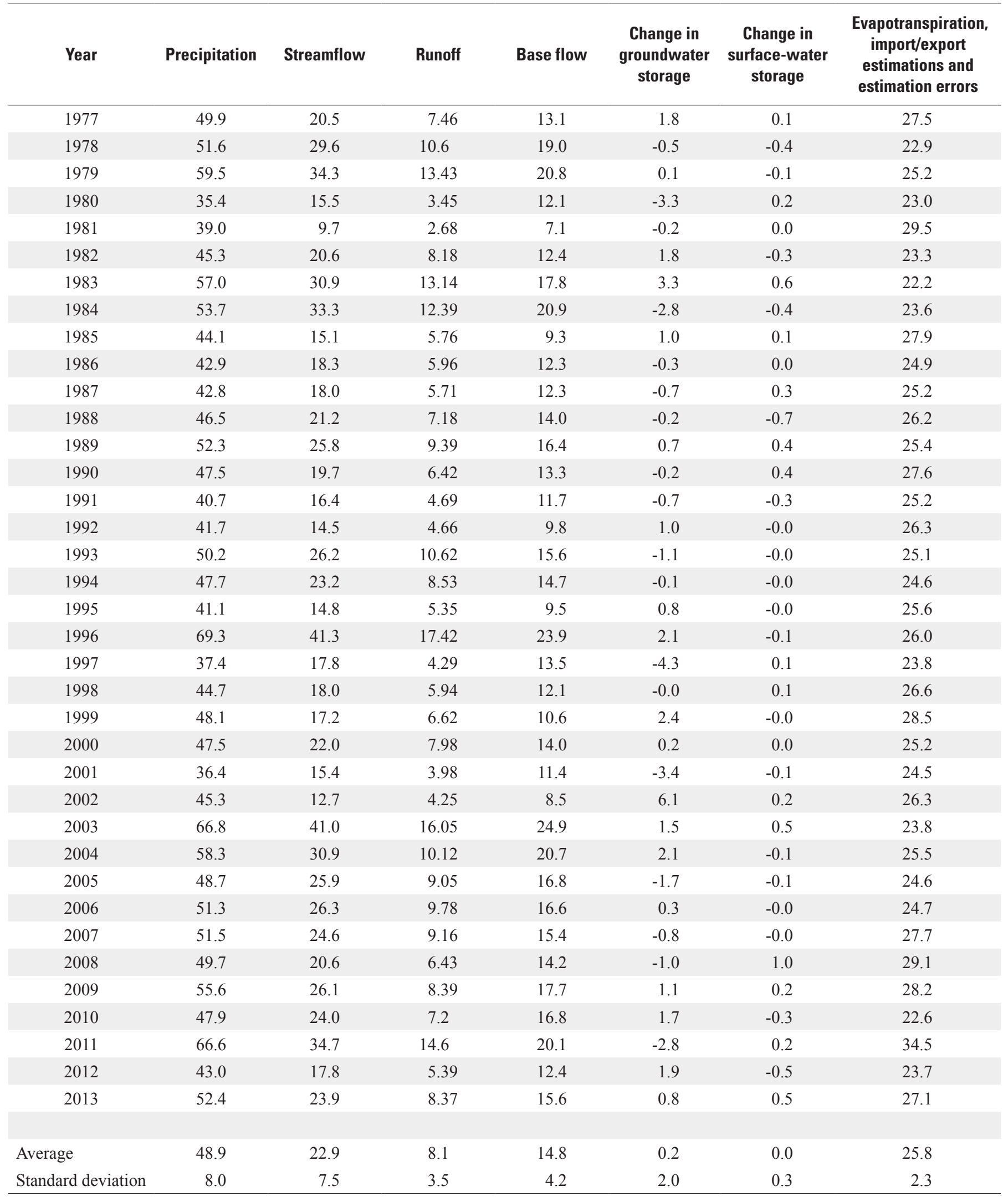


evapotranspiration, import/export estimations, and estimation errors ranged from 22 in. to $32 \mathrm{in.} \mathrm{with} \mathrm{an} \mathrm{average} \mathrm{of} 27 \mathrm{in}$.

A water budget was developed for Big Elk Creek upstream from streamgage 01495000 (Big Elk Creek at Elk Mills, Md.) for 1988-2013 (table 32). Annual precipitation ranged from $35 \mathrm{in}$. to $64 \mathrm{in}$. with an average of $47 \mathrm{in}$. Annual streamflow ranged from $9 \mathrm{in}$. to $34 \mathrm{in}$. with an average of $20 \mathrm{in}$. Annual streamflow ranged from 23 percent of precipitation to 57 percent of precipitation with an average of 41 percent. Annual runoff ranged from $3 \mathrm{in}$. to $16 \mathrm{in}$. with an average of $7 \mathrm{in}$. Annual base flow ranged from $6 \mathrm{in}$. to $18 \mathrm{in}$. with an average of $12 \mathrm{in}$. Annual base flow ranged from 51 percent of streamflow to 76 percent of streamflow with an average of 63 percent. Annual base flow ranged from 14 percent of precipitation to 37 percent of precipitation with an average of 26 percent. Imports of water into the watershed ranged from $0.4 \mathrm{in}$. to $0.09 \mathrm{in}$. from 1997 to 2013 . The annual change in groundwater storage ranged from a loss of $4 \mathrm{in}$. to a gain of $8 \mathrm{in}$. with an average change of $0 \mathrm{in}$. Annual evapotranspiration, import/export estimations, and estimation errors ranged from $20 \mathrm{in}$. to $34 \mathrm{in}$. with an average of $28 \mathrm{in}$.

An average water budget was calculated for Chester County using the nine watersheds (table 33 ). Average annual precipitation ranged from 35 in to 67 in. with an average of $48 \mathrm{in.}$ Average annual streamflow ranged from 9 in. to $37 \mathrm{in.}$ with an average of $21 \mathrm{in}$. Average annual streamflow ranged from 24 percent of precipitation to 59 percent of precipitation with an average of 43 percent. Average annual runoff ranged from 3 in. to $17 \mathrm{in}$. with an average of 8 in. Average annual base flow ranged from 6 in. to $20 \mathrm{in}$. with an average of 13 in. Average annual base flow ranged from 53 percent of streamflow to 75 percent of streamflow with an average of 62 percent. Average annual base flow ranged from 15 percent of precipitation to 35 percent of precipitation with an average of 27 percent. The average annual change in groundwater storage ranged from a loss of 4 in. to a gain of 3 in. with an average of 0 in. Average annual evapotranspiration plus estimation errors ranged from 22 in. to 33 in. with an average of 27 in.

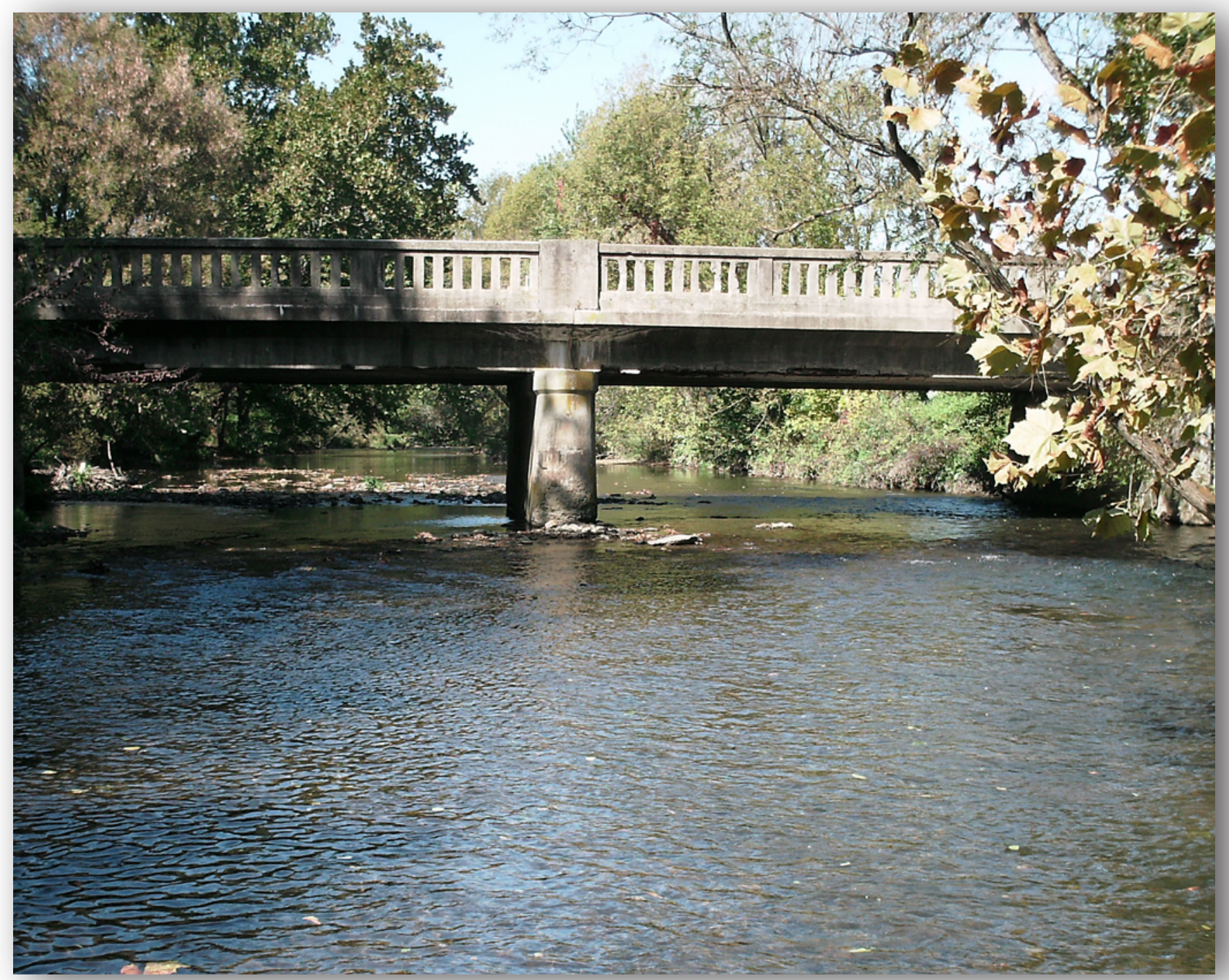

Photo of West Branch Brandywine Creek at Modena, Pa. (Photograph provided by Andrew Reif, U.S. Geological Survey) 
Table 31. Water budget for Brandywine Creek watershed upstream from streamgage 01481000, Brandywine Creek at Chadds Ford, Pennsylvania, 1963-2013.

[Values are in inches per year. Negative change indicates a decrease in groundwater or surface-water storage. Positive change indicates an increase in groundwater or surface-water storage]

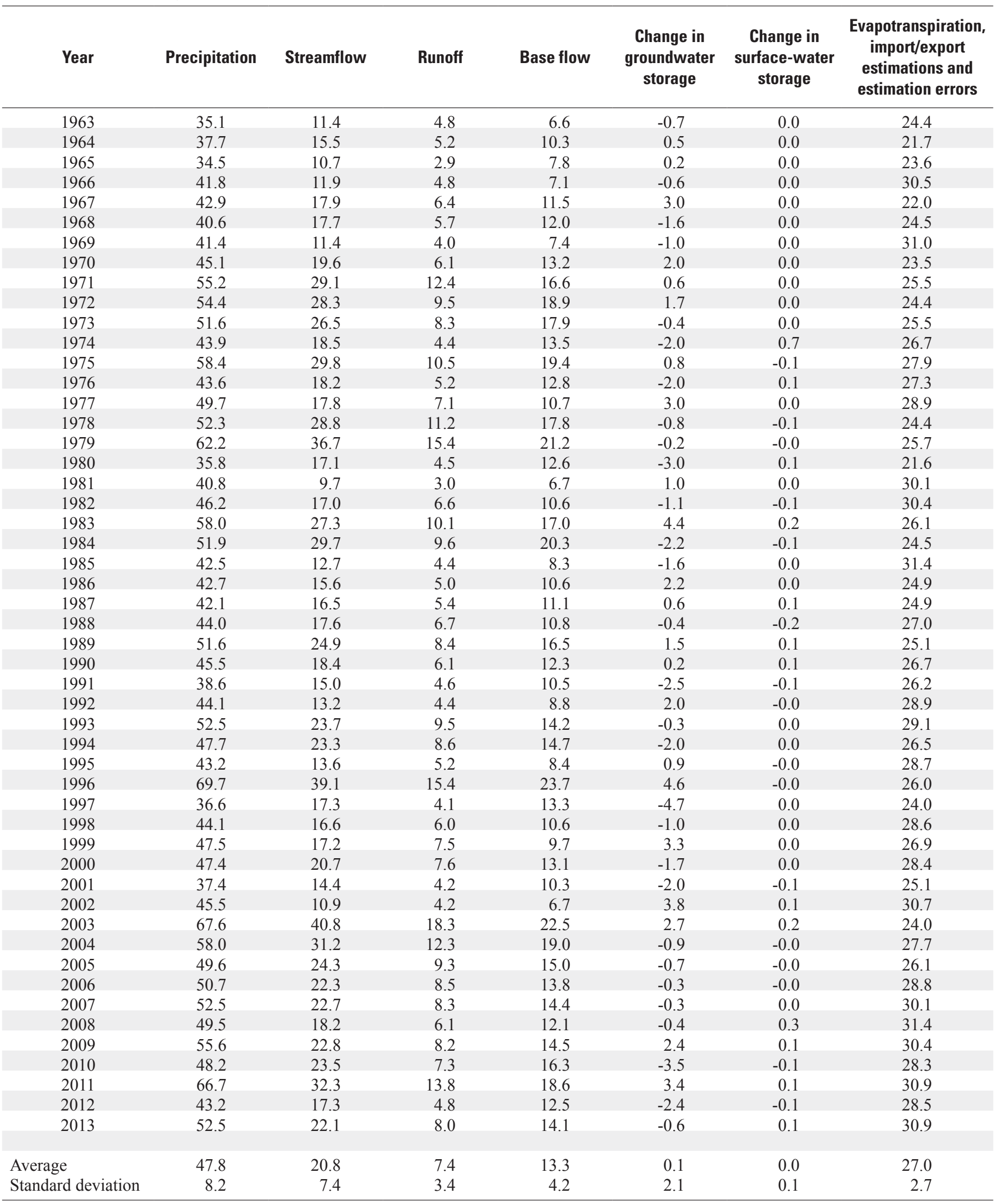


Table 32. Water budget for Big Elk Creek watershed upstream from streamgage 01495000, Big Elk Creek at Elk Mills, Maryland, 1988-2013.

[Values are in inches per year. Negative change indicates a decrease in groundwater storage. Positive change indicates an increase in groundwater storage]

\begin{tabular}{|c|c|c|c|c|c|c|}
\hline Year & Precipitation & Streamflow & Runoff & Base flow & $\begin{array}{l}\text { Change in } \\
\text { groundwater } \\
\text { storage }\end{array}$ & $\begin{array}{c}\text { Evapotranspiration } \\
\text { import/export } \\
\text { estimations and } \\
\text { estimation errors }\end{array}$ \\
\hline 1988 & 42.1 & 16.9 & 6.6 & 10.3 & -0.6 & 25.8 \\
\hline 1989 & 52.7 & 25.3 & 10.1 & 15.2 & 5.9 & 21.5 \\
\hline 1991 & 36.0 & 13.8 & 3.5 & 10.3 & -3.1 & 25.3 \\
\hline 1992 & 42.5 & 13.8 & 5.0 & 8.8 & -1.4 & 30.1 \\
\hline 1993 & 49.9 & 22.4 & 8.3 & 14.1 & 3.3 & 24.2 \\
\hline 1996 & 61.7 & 33.7 & 16.3 & 17.4 & 8.3 & 19.7 \\
\hline 1997 & 35.5 & 17.3 & 4.1 & 13.2 & -4.0 & 22.2 \\
\hline 1998 & 41.0 & 14.6 & 5.0 & 9.6 & -0.1 & 26.6 \\
\hline 1999 & 53.3 & 16.8 & 8.4 & 8.4 & 2.8 & 33.7 \\
\hline 2000 & 44.4 & 18.6 & 6.7 & 11.9 & -0.4 & 26.2 \\
\hline 2001 & 35.2 & 12.9 & 4.6 & 8.3 & -2.6 & 24.9 \\
\hline 2006 & 49.0 & 19.2 & 7.1 & 12.1 & -0.7 & 30.5 \\
\hline 2007 & 42.2 & 18.6 & 6.1 & 12.5 & -1.9 & 25.5 \\
\hline 2008 & 46.5 & 14.3 & 4.8 & 9.5 & -0.3 & 32.5 \\
\hline 2009 & 55.4 & 21.1 & 8.3 & 12.8 & 3.3 & 31.0 \\
\hline 2010 & 47.1 & 22.6 & 6.8 & 15.8 & -2.3 & 26.8 \\
\hline 2011 & 62.9 & 28.4 & 12.4 & 16.0 & 2.7 & 31.8 \\
\hline 2012 & 45.3 & 15.9 & 4.9 & 11.0 & -3.7 & 33.1 \\
\hline 2013 & 55.0 & 23.6 & 9.6 & 14.0 & 1.8 & 29.6 \\
\hline Average & 47.5 & 19.7 & 7.5 & 12.3 & 0.2 & 27.5 \\
\hline Standard deviation & 8.1 & 6.1 & 3.3 & 3.2 & 3.3 & 3.9 \\
\hline
\end{tabular}


Table 33. Average water budget in Chester County, Pennsylvania, based on 2 to 9 individual watershed water budgets, 1969-2013.

[Values are in inches per year. Negative change indicates a decrease in groundwater storage. Positive change indicates an increase in groundwate storage]

\begin{tabular}{|c|c|c|c|c|c|c|c|}
\hline Year & $\begin{array}{l}\text { Number of } \\
\text { individual water } \\
\text { budgets used } \\
\text { to calculate } \\
\text { average }\end{array}$ & Precipitation & Streamflow & Runoff & Base flow & $\begin{array}{l}\text { Change in } \\
\text { groundwater } \\
\text { storage }\end{array}$ & $\begin{array}{l}\text { Evapotranspiration } \\
\text { and estimation } \\
\text { errors }\end{array}$ \\
\hline 1969 & 2 & 39.3 & 10.5 & 3.7 & 6.8 & -0.6 & 29.4 \\
\hline 1970 & 2 & 43.4 & 18.2 & 6.0 & 12.1 & 1.5 & 23.6 \\
\hline 1971 & 2 & 54.6 & 27.0 & 11.8 & 15.2 & 0.6 & 27.0 \\
\hline 1972 & 2 & 55.9 & 29.7 & 11.3 & 18.4 & 1.5 & 24.7 \\
\hline 1973 & 2 & 51.5 & 26.6 & 9.3 & 17.2 & -0.4 & 25.2 \\
\hline 1974 & 4 & 43.7 & 17.7 & 5.4 & 12.2 & -1.6 & 27.4 \\
\hline 1975 & 4 & 56.9 & 27.3 & 10.8 & 16.6 & 1.2 & 28.4 \\
\hline 1976 & 4 & 44.6 & 19.0 & 6.9 & 12.0 & -2.0 & 27.6 \\
\hline 1977 & 4 & 48.8 & 19.2 & 7.7 & 11.5 & 2.4 & 27.3 \\
\hline 1978 & 6 & 50.5 & 28.8 & 11.9 & 16.9 & -0.4 & 22.2 \\
\hline 1979 & 6 & 59.0 & 32.7 & 14.6 & 18.0 & -0.1 & 26.5 \\
\hline 1980 & 6 & 34.8 & 15.7 & 4.3 & 11.4 & -3.8 & 23.0 \\
\hline 1981 & 6 & 38.5 & 9.1 & 3.1 & 6.0 & 0.7 & 28.7 \\
\hline 1982 & 6 & 45.8 & 18.0 & 7.7 & 10.3 & 1.7 & 26.4 \\
\hline 1983 & 6 & 56.5 & 27.9 & 12.2 & 15.6 & 2.7 & 25.9 \\
\hline 1984 & 6 & 52.3 & 30.7 & 12.3 & 18.5 & -2.2 & 24.1 \\
\hline 1985 & 6 & 43.5 & 14.0 & 5.5 & 8.5 & 0.4 & 29.2 \\
\hline 1986 & 6 & 42.5 & 16.6 & 6.1 & 10.5 & 0.4 & 25.6 \\
\hline 1987 & 6 & 42.0 & 17.2 & 6.4 & 10.8 & -0.2 & 25.1 \\
\hline 1988 & 8 & 51.4 & 24.0 & 9.0 & 15.1 & 1.5 & 26.3 \\
\hline 1989 & 8 & 46.4 & 18.8 & 6.6 & 12.1 & -0.3 & 28.4 \\
\hline 1990 & 8 & 38.8 & 14.6 & 4.3 & 10.3 & -1.7 & 26.5 \\
\hline 1991 & 8 & 42.6 & 13.5 & 4.9 & 8.6 & 0.7 & 28.9 \\
\hline 1992 & 8 & 51.0 & 23.8 & 9.7 & 14.1 & 0.5 & 27.3 \\
\hline 1993 & 8 & 46.9 & 22.1 & 8.4 & 13.7 & -1.0 & 26.3 \\
\hline 1994 & 8 & 41.5 & 13.7 & 5.4 & 8.3 & -0.0 & 28.4 \\
\hline 1995 & 8 & 67.3 & 37.3 & 17.2 & 20.1 & 3.4 & 27.3 \\
\hline 1996 & 8 & 36.2 & 16.4 & 4.1 & 12.2 & -3.8 & 24.2 \\
\hline 1997 & 8 & 43.4 & 16.8 & 6.0 & 10.8 & -0.4 & 27.6 \\
\hline 1998 & 8 & 47.4 & 16.6 & 7.6 & 9.1 & 1.9 & 29.4 \\
\hline 1999 & 8 & 46.7 & 19.9 & 7.5 & 12.4 & -0.1 & 27.4 \\
\hline 2000 & 8 & 36.5 & 14.1 & 4.7 & 9.4 & -2.3 & 25.3 \\
\hline 2001 & 8 & 44.2 & 11.4 & 4.8 & 6.6 & 2.1 & 31.1 \\
\hline 2002 & 8 & 65.9 & 36.5 & 17.0 & 19.5 & 3.2 & 26.7 \\
\hline 2003 & 8 & 57.1 & 30.3 & 12.1 & 18.2 & 0.2 & 27.2 \\
\hline 2004 & 8 & 47.7 & 24.4 & 9.3 & 15.1 & -1.2 & 25.1 \\
\hline 2005 & 9 & 47.6 & 24.2 & 8.9 & 15.3 & -1.1 & 25.0 \\
\hline 2006 & 9 & 50.5 & 21.8 & 8.4 & 13.4 & -0.1 & 29.4 \\
\hline 2007 & 9 & 50.4 & 21.6 & 8.3 & 13.3 & -0.6 & 29.9 \\
\hline 2008 & 9 & 48.8 & 18.4 & 6.6 & 11.8 & 0.0 & 30.7 \\
\hline 2009 & 9 & 55.2 & 23.6 & 9.1 & 14.5 & 1.5 & 30.7 \\
\hline 2010 & 9 & 48.3 & 22.1 & 7.2 & 14.9 & -1.4 & 28.2 \\
\hline 2011 & 9 & 65.8 & 31.4 & 13.9 & 17.5 & 1.5 & 33.4 \\
\hline 2012 & 9 & 43.1 & 16.5 & 5.2 & 11.3 & -1.6 & 28.8 \\
\hline 2013 & 9 & 52.4 & 22.7 & 8.7 & 14.0 & 1.0 & 29.1 \\
\hline Average & & 48.4 & 21.4 & 8.3 & 13.1 & 0.1 & 27.2 \\
\hline Standard deviation & & 7.6 & 6.7 & 3.4 & 3.5 & 1.6 & 2.3 \\
\hline
\end{tabular}




\section{Summary and Conclusions}

Chester County, Pennsylvania, has experienced a rapid increase in population since 1950. Most of this population growth is suburban with the conversion of farmland and woodland to housing developments and commercial uses. During 1963-2013, hydrologic data, including streamflow, groundwater levels, and surface-water quality, have been collected by the U.S. Geological Survey (USGS) on a systematic basis. This study, conducted by the USGS in cooperation with the Chester County Water Resources Authority, evaluated the long-term trends in hydrologic data.

Annual and monthly mean streamflow, base flow, and runoff were tested for statistically significant trends for the period of record for 10 streamgages. The only statistically significant trend for annual mean streamflow was for West Branch Brandywine Creek near Honey Brook Pa. (01480300), which increased 1.6 cubic feet per second $\left(\mathrm{ft}^{3} / \mathrm{s}\right)$ per decade. The greatest increase in monthly mean streamflow was for Brandywine Creek at Chadds Ford, Pa. (01481000) for December; the increase was $47 \mathrm{ft}^{3} / \mathrm{s}$ per decade.

The magnitudes of annual peaks and, where available, peaks above the base streamflow were tested for statistically significant trends for the period of record for 11 streamgages. Fifty percent of the streamgages showed a small statistically significant increase. The greatest increase was for Brandywine Creek at Chadds Ford, Pa. (01481000) for 1962-2012; the increase was $1.8 \mathrm{ft}^{3} / \mathrm{s}$ per decade. The frequency and number of floods equal to or greater than the 2-year recurrence interval (for this report considered bank full flow) were tested for statistically significant trends for the period of record for 11 streamgages. There were no statistically significant trends for peak streamflow equal to or greater than the 2-year recurrence interval or the number of annual peak streamflows at or above the 2-year recurrence interval.

Annual mean water level below land surface, annual minimum (highest) water level, maximum (lowest) water level, and annual range in water-level fluctuations were evaluated for 21 monitoring wells for statistically significant trends. Four wells exhibited a small statistically significant increase in annual mean water level that ranged from 0.16 to 0.74 foot per decade. No wells had a statistically significant decrease in annual mean water level. Well CH-10 was the only well to exhibit a statistically significant increase in annual range of water-level fluctuation.

Most of the correlations that were conducted to evaluate water resources in Chester County between 1970 and 2013 indicated no significant increase or decrease in streamflow, base flow, or groundwater levels. Trends that were significant generally had slopes that indicate the changes were small and occurred gradually.

Long-term precipitation and temperature data for Chester County are available from the West Chester (1893-2013) and Phoenixville (1915-2013) National Oceanic and Atmospheric Administration (NOAA) weather stations. There were no statistically significant trends in annual mean precipitation or annual mean temperature for either weather station. Both weather stations showed a decrease in the number of days per year with precipitation greater than or equal to 0.1 inch (in.); however, there was no statistically significant trend in the number of days per year with precipitation greater than or equal to 0.5 or $1 \mathrm{in}$. Average annual estimated winter snowfall ranged from $2.9 \mathrm{in}$. during the winter of 1971-72 to $81.8 \mathrm{in}$. during the winter of 1995-96. No statistically significant trend was determined for annual snowfall amounts.

Annual mean minimum and maximum temperature from the NOAA Southeastern Piedmont Climate Division increased 0.2 degrees Fahrenheit (F) per decade between 1896 and 2014. No statistically significant trend was determined for the number of days per year with temperature greater than or equal to 0 degrees $\mathrm{F}$ at either weather station. The number of days with a maximum temperature greater than or equal to 90 degrees $\mathrm{F}$ increased at West Chester and decreased at Phoenixville. At West Chester the number of days per year with a maximum temperature equal to or greater than 90 degrees $\mathrm{F}$ increased 1.3 days per decade, whereas at Phoenixville, the number of days per year decreased 1.1 days per decade.

Three stream water-quality monitors have been in operation on the Brandywine Creek since 1965. The monitors operate in non-winter months (March 1 through November 30) and measure $\mathrm{pH}$, specific conductance, temperature, and dissolved oxygen concentration. Because of regulation by Marsh Creek Reservoir beginning in 1974, and to provide a concurrent period of record for analysis, data from 1974 to 2014 were evaluated for the three stream water-quality stations. Minimum pH less than 6.0 was uncommon at any of the three stream water-quality stations. Maximum daily $\mathrm{pH}$ greater than 9.0 was rarely measured at East Branch Brandywine Creek below Downingtown, Pa. (01480870) or Brandywine Creek at Chadds Ford, Pa. (01481000) but was regularly measured at West Branch Brandywine Creek at Modena, Pa. (01480617). Prior to 1988, it was common in the summer months for minimum daily dissolved oxygen concentrations at East Branch Brandywine Creek below Downingtown, Pa. (01480870) and West Branch Brandywine Creek at Modena, Pa. (01480617) to be less than 6 milligrams per liter $(\mathrm{mg} / \mathrm{L})$. Since 1988, the number of days the minimum dissolved oxygen was less than $6 \mathrm{mg} / \mathrm{L}$ has decreased at East Branch Brandywine Creek below Downingtown, Pa. (01480870) and West Branch Brandywine Creek at Modena, Pa. (01480617). The monitoring data indicate a substantial improvement in the $\mathrm{pH}$ and dissolved oxygen concentration in the Brandywine Creek over time.

Trends were evaluated for 1974-2013 for annual mean specific conductance, $\mathrm{pH}$, stream temperature, and dissolved oxygen concentration. Statistically significant upward trends were observed for annual mean specific conductance at all three stream water-quality stations. The increase in specific conductance was 22 microsiemens per centimeter at 25 degrees Celsius $\left(\mu \mathrm{S} / \mathrm{cm}\right.$ at $\left.25^{\circ} \mathrm{C}\right)$ per decade at West Branch Brandywine Creek at Modena, Pa. (01480617) and $23 \mu \mathrm{S} / \mathrm{cm}$ at $25^{\circ} \mathrm{C}$ per decade at East Branch Brandywine Creek below Downingtown, Pa. (01480870) and Brandywine 
Creek at Chadds Ford, Pa. (01481000). If the current trend continues, the annual mean specific conductance could be as high as $395-444 \mu \mathrm{S} / \mathrm{cm}$ at $25^{\circ} \mathrm{C}$ at the three sites by 2050 . This indicates that total dissolved solids load has been increasing with time at the three stream water-quality monitoring stations. The increase in specific conductance likely is due to increases in chloride. The chloride concentration has increased steadily over time at all three stream water-quality monitoring stations.

Statistically significant upward trends in $\mathrm{pH}$ were observed at all three water-quality stations. The increase in $\mathrm{pH}$ is very small, only $0.08 \mathrm{pH}$ unit per decade at Modena, $0.1 \mathrm{pH}$ unit per decade at Downingtown, and $0.04 \mathrm{pH}$ unit per decade at Chadds Ford.

Statistically significant upward trends in stream temperature were observed for the East Branch Brandywine Creek below Downingtown, Pa. (01480870) and Brandywine Creek at Chadds Ford, Pa. (01481000) stations. The increase in stream temperature was 0.5 degree Celsius (C) ( 0.9 degree F) per decade at East Branch Brandywine Creek below Downingtown, Pa. (01480870) and 0.6 degree C (1 degree F) per decade at Brandywine Creek at Chadds Ford, Pa. (01481000). There was a statistically significant increase in dissolved oxygen concentration at West Branch Brandywine Creek at Modena, Pa. (01480617); the increase is 0.2 milligrams per liter per decade. Virtually no correlation was found between monthly mean specific conductance and mean monthly streamflow or base flow.

The Stream Conditions of Chester County Biological Monitoring Network was established in 1969. Data from 1998 to 2009 were used to establish the Chester County Index of Biotic Integrity (CC-IBI). The CC-IBI from 1998 to 2013 was evaluated for the five biological sampling sites located at streamgages. CC-IBI scores are based on a 0-100 scale with higher scores indicating better stream quality. Statistically significant upward trends in the CC-IBI were observed at the two sites in the Brandywine Creek watershed-West Branch Brandywine Creek at Modena, Pa. (01480617) and East Branch Brandywine Creek below Downingtown, Pa. (01480870). No trend was observed for the other three sites evaluated.

Linear regression was used to determine whether a correlation exists between the CC-IBI for 1998-2013 and (1) mean, minimum, and maximum daily streamflow during the 6 and 12 months prior to the day of sampling; (2) the most recent large peak streamflow; (3) days since most recent large peak streamflow; (4) greatest peak streamflow during the 6 and 12 months prior to the day of sampling; (5) days since the largest peak streamflow during the 6 and 12 months prior to the day of sampling; (6) number of days streamflow was less than a selected low threshold streamflow in the 6 months prior to the day of sampling; (7) total and maximum daily precipitation during the 6 and 12 months prior to the day of sampling; and (8) mean, minimum, and maximum monthly air temperature during the 6 and 12 months prior to the day of sampling. The CC-IBI was poorly correlated with all of these factors.

Linear regression was used to determine whether a correlation exists between the CC-IBI for 1998-2013 and the mean, minimum, and maximum stream specific conductance, $\mathrm{pH}$, stream temperature, and dissolved oxygen concentration at East Branch Brandywine Creek below Downingtown, Pa. (01480870) and West Branch Brandywine Creek at Modena, Pa. (01480617) during the 6 months prior to the day of sampling. The CC-IBI did not correlate with water quality. A single factor is not responsible for changes in the biological community over time.

Water budgets were developed for nine Chester County watersheds. An average water budget was calculated for Chester County using data from the nine watersheds. Annual precipitation ranged from 35 in to $67 \mathrm{in}$. with an average of $48 \mathrm{in}$. Average annual streamflow ranged from 9 in. to $37 \mathrm{in}$. with an average of $21 \mathrm{in.} \mathrm{Average} \mathrm{annual} \mathrm{runoff} \mathrm{ranged} \mathrm{from} 3 \mathrm{in}$. to $17 \mathrm{in}$. with an average of $8 \mathrm{in}$. Average annual base flow ranged from 6 in. to 20 in. with an average of 13 in. Average annual base flow ranged from 15 percent of precipitation to 35 percent of precipitation with an average of 27 percent. The average annual change in groundwater storage ranged from a loss of 4 in. to a gain of 3 in. with an average of 0 in. Average annual evapotranspiration plus estimation errors ranged from $22 \mathrm{in.} \mathrm{to} 33 \mathrm{in}$. with an average of $27 \mathrm{in}$.

\section{References Cited}

Cinotto, P.J., Reif, A.G., and Olson, L.E., 2005, Environmental setting, water budget, and stream assessment for the Broad Run watershed, Chester County, Pennsylvania: U.S. Geological Survey Water-Resources Investigations Report 2005-5156, 67 p.

Hardy, M.A., Wetzel, K.L., and Moore, C.R., 1995, Land use, organochlorine compound concentrations, and trends in benthic invertebrate communities in selected stream basins in Chester County, Pennsylvania: U.S. Geological Survey Water-Resources Investigations Report 94-4060, 78 p.

Kappel, W.M., Sinclair, G.J., Reddy, J.E., Eckhardt, D.A., deVries, M.P., and Phillips, M.L., 2012, Specific conductance measurements in central and western New York streams- a retrospective characterization: U.S. Geological Survey Open-File Report 2012-1174, 6 p.

Kendall, Maurice, 1938, A new measure of rank correlation: Biometrika, v. 30, no. 1-2, p. 81-89. 
McGreevy, L.J., and Sloto, R.A., 1980, Development of a digital model of ground-water flow in deeply weathered crystalline rock, Chester County, Pennsylvania: U.S. Geological Survey Water-Resources Investigations Report 80-2, 42p.

Moore, C.R., 1987, Determination of benthic-invertebrate indices and water-quality trends of selected streams in Chester County, Pennsylvania: U.S. Geological Survey Water-Resources Investigations Report 85-4177, 62 p.

Moore, C.R., 1989, Physical, chemical, and biological data for selected streams in Chester County, Pennsylvania, 1969-80: U.S. Geological Survey Open-File Report 85-686, 289 p.

Murphy, J.J., Ritter, J.R., Brown, A.E., and Chiarella, J.P., 1982, An evaluation of water-quality monitoring in the Brandywine Creek basin, Pennsylvania, 1973-78: U.S. Geological Survey Open-File Report 81-1115, 28 p.

National Oceanic and Atmospheric Administration, 2014, Monthly observation data, accessed September 9, 2014, at http://gis.ncdc.noaa.gov/map/viewer/\#app=cdo\&cfg=cdo\&t heme $=$ monthly\&layers $=1$.

Novak, C.E., 1985, WRD data reports preparation guide: U.S. Geological Survey Water Resources Division, 199 p.

Reif, A.G., 1999, Physical, chemical, and biological data for selected streams in Chester County, Pennsylvania, 1981-94: U.S. Geological Survey Open-File Report 99-216, 607 p.

Reif, A.G., 2000, Physical, chemical, and biological data for selected streams in Chester County, Pennsylvania, 1995-97: U.S. Geological Survey Open-File Report 00-238, 146 p.

Reif, A.G., 2002, Assessment of stream conditions and trends in biological and water-chemistry data from selected streams in Chester County, Pennsylvania, 1981-97: U.S. Geological Survey Water-Resources Investigations Report 02-4242, $77 \mathrm{p}$.

Reif, A.G., 2004, Assessment of water chemistry, habitat, and benthic macroinvertebrates at selected stream-quality monitoring sites in Chester County, Pennsylvania, 1998-2000: U.S. Geological Survey Open-File Report 03-499, 84 p.

Reif, A.G., 2012, A benthic-macroinvertebrate index of biotic integrity and assessment of conditions in selected streams in Chester County, Pennsylvania, 1998-2009: U.S. Geological Survey Scientific Investigations Report 2012-5116, 41 p.

Sen, P.K., 1968, Estimates of the regression coefficient based on Kendall's tau: Journal of the American Statistical Association, v. 63, p.1379-1389.
Sloto, R.A., 1994, Geology, hydrology, and ground-water quality of Chester County, Pennsylvania: Chester County Water Resources Authority Water Resources Report 2, $118 \mathrm{p}$.

Sloto, R.A., 2002, Hydrogeology and ground-water quality, Big Elk Creek Basin, Chester County, Pennsylvania and Cecil County, Maryland: U.S. Geological Survey WaterResources Investigations Report 02-4057, $81 \mathrm{p}$.

Sloto, R.A., 2004, Geohydrology of the French Creek Basin and simulated effects of drought and ground-water withdrawals, Chester County, Pennsylvania: U.S. Geological Survey Water-Resources Investigations Report 03-4263, $82 \mathrm{p}$.

Sloto, R.A., and Buxton, D.E., 2005, Water budgets for selected watersheds in the Delaware River Basin, Eastern Pennsylvania and western New Jersey: U.S. Geological Survey Scientific investigations Report 2005-5113, 37 p.

Sloto, R.A., and Crouse, M.Y., 1996, HYSEP: A computer program for streamflow hydrograph separation and analysis: U.S. Geological Survey Water-Resources Investigations Report 96-4040, 46 p.

Thiessen, A.H., 1911, Precipitation for large areas: Monthly Weather Review, v. 29, p. 1082-1084.

U.S. Census Bureau, 2014, Annual estimates of the resident population: April 1, 2010 to July 1, 2013, accessed December 16, 2014, at http://factfinder2.census.gov/faces/tableservices/jsf/pages/productview.xhtml? src $=\mathrm{CF}$.

U.S. Environmental Protection Agency, 2009, National Recommended Water Quality Criteria: Washington, D.C., U.S. Environmental Protection Agency, Office of Science and technology, EPA 4304T, 21p.

U.S. Geological Survey, 2002-13, Water-resources data for Pennsylvania water year 2002-13: U.S. Geological Survey Water-Data Report WRD-US-2002-2013, accessed January 18, 2017, at http://pa.water.usgs.gov/infodata/surfacewater/ annual_rpt.

U.S. Geological Survey, 2014, USGS Current Water Data for the Nation, accessed December 4, 2014, at http://waterdata. usgs.gov/nwis/rt.

Vogel, K.L., and Reif, A.G., 1993, Geohydrology and simulation of ground-water flow in the Red Clay Creek Basin, Chester County, Pennsylvania, and New Castle County, Delaware: U.S. Geological Survey Water-Resources Investigations Report 93-4055, $111 \mathrm{p}$. 
Publishing support provided by the U.S. Geological Survey Science Publishing Network, West Trenton Publishing Service Center

For more information concerning the research in this report, contact: Director, Pennsylvania Water Science Center

U.S. Geological Survey

215 Limekiln Road

New Cumberland, Pa. 17070

http://pa.water.usgs.gov/ 
